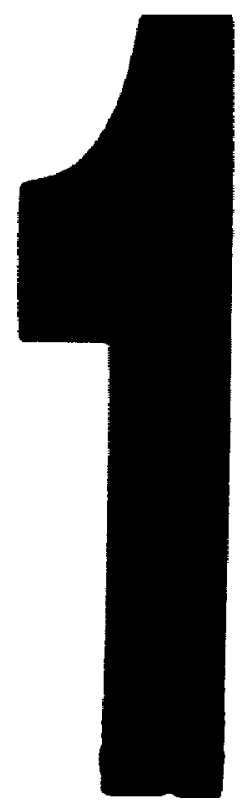

PM-1 3: $: 4$ PHOTOGRAPHIC MICROCOPY TARGET NES 1010a ANSI/ISO "2 EOUIVALENT

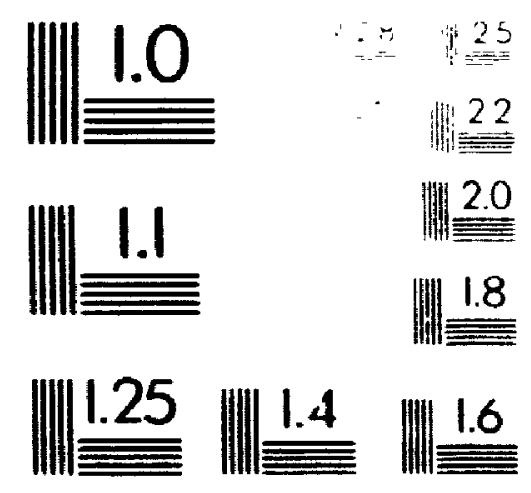

PRECISIONSM RESOLUTION TARGETS 


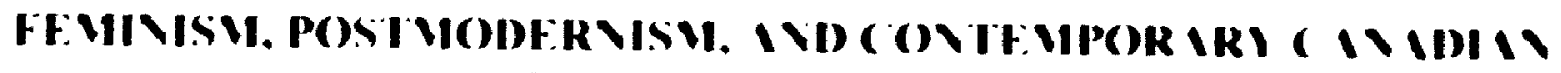
WRITIV; BI WONEY

\author{
b! \\ IIRG ARI I BRIS KIR. B I
}

I thes ushmited to the

Faculty of (iraduate Studes and Revearch

in partial fulfilment of the requirements for the degree of

Vaver of Ints

The School of Comparatue! Iterany Studes

Carleton I mucisily Ottawa. Ontario

September 1. 10\%,

(opynght 1909. Margaret Brickes 
The author has granted an irrevocable non-exclusive licence allowing the National Library of Canada to reproduce, loan, distribute or sell copies of his/her thesis by any means and in any form or format, making this thesis available to interested persons.
L'auteur a accordé une licence irrévocable et non exclusive permettant à la Bibliothèque nationale du Canada de reproduire, prêter, distribuer ou vendre des copies de sa thèse de quelque manière et sous quelque forme que ce soit pour mettre des exemplaires de cette thèse à la disposition des personnes intéressées.
The author retains ownership of the copyright in his/her thesis. Neither the thesis nor substantial extracts from it may be printed or otherwise reproduced without his/her permission.
L'auteur conserve la propriété du droit d'auteur qui protège sa thèse. Ni la thèse ni des extraits substantiels de celle-ci ne doivent être imprimés ou autrement reproduits sans son autorisation.

ISBN $\quad 0-612-19417-5$ 
Nom

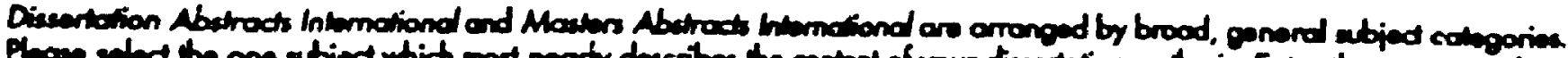

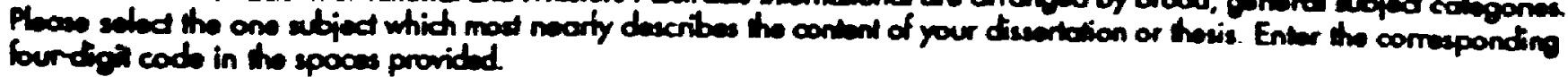

\section{Subject Cologories}

\section{rect cods}

\section{THE MUMANTIES AND SOCIAL SCIENCES}

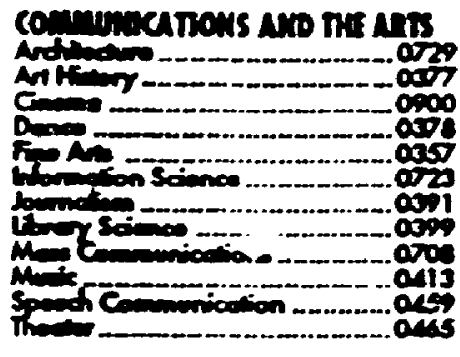

\section{Bacanom}

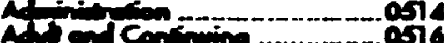

4 ion

A -

A

Com

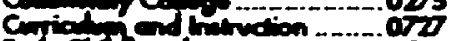

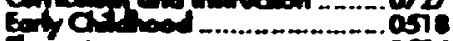

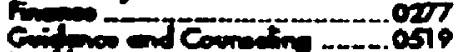

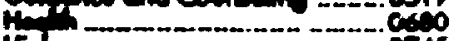

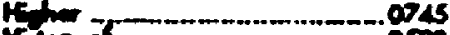
tor _ _.......................

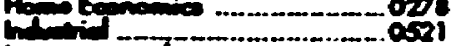

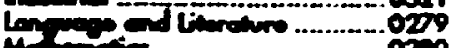
Me

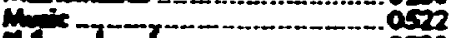
Rrbar

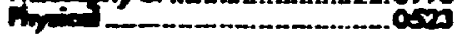

G ب -

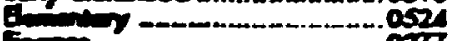

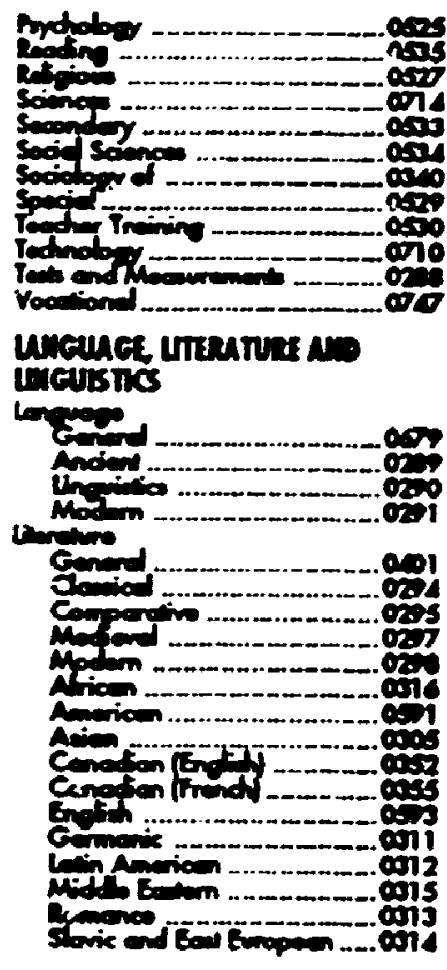

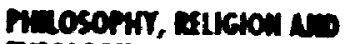
nicosost

ation

Pot

sem

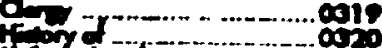

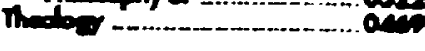

soan sames

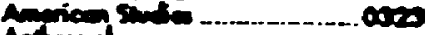

Arverebry

Andinoby _...........21

Fing -

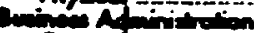

Cen _a.____ $\infty 10$

noppon -.......

Min -

$m+100$

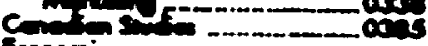

Bencomic

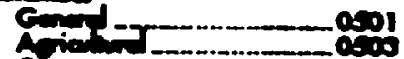

Crions

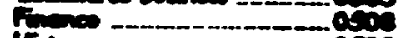

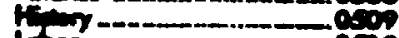

Tw

Comply

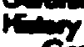

assi

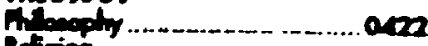

tompd

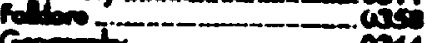

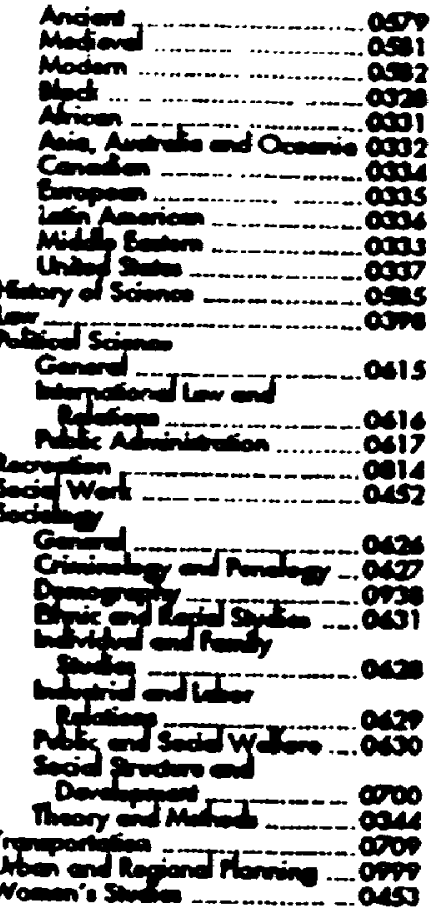

\section{THE SCIENCES AND ENGINEERINO}

\section{motexen sanes}

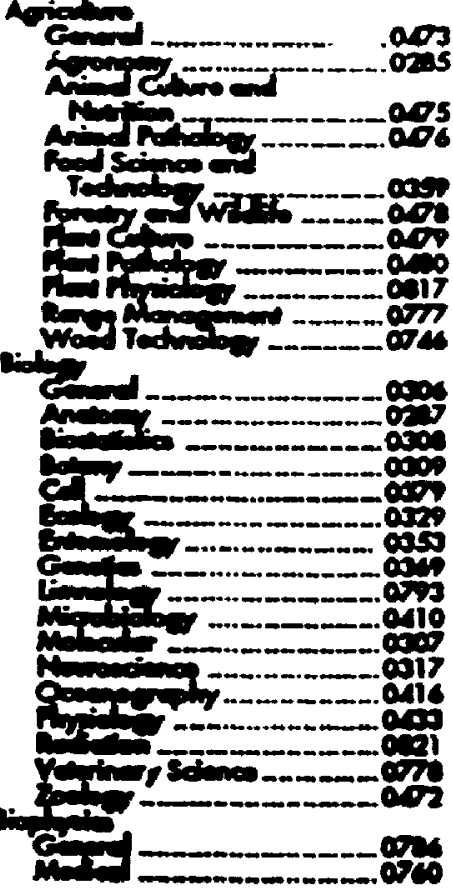

Mulle:as

cons

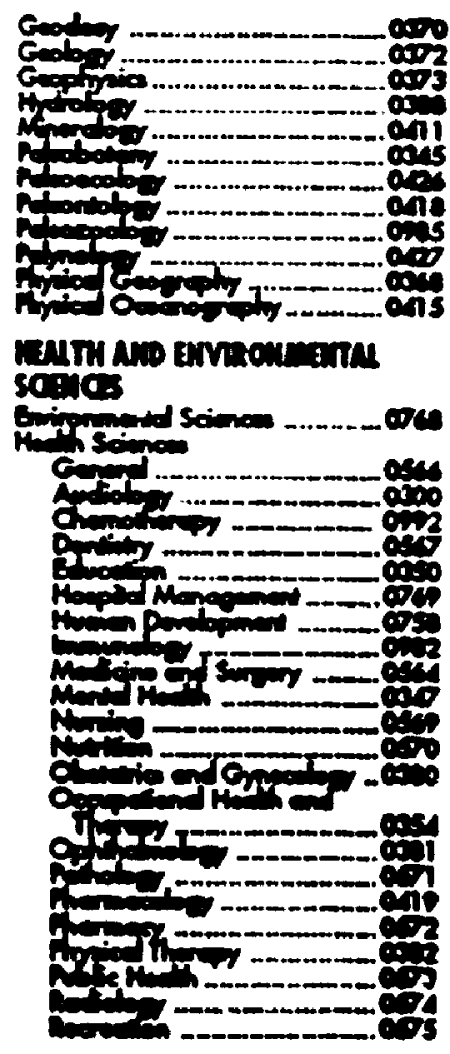

Bunarix

.

Henowar

Puisucu somas

gre Seland

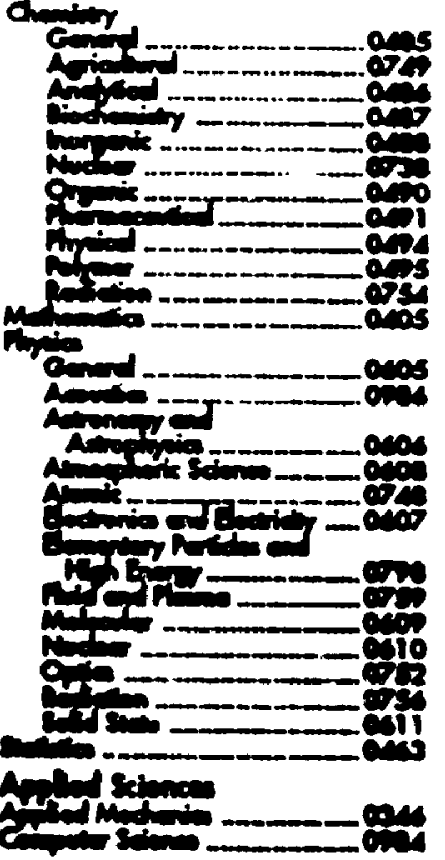

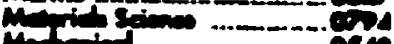

Aropen

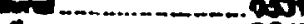

Them

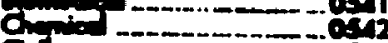

Cx-m -

in

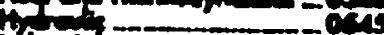

wh -

Min

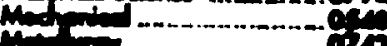

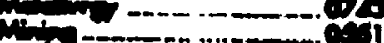

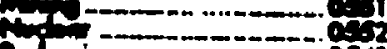

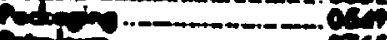

nom

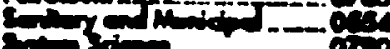

c

gran

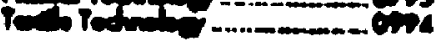

Griver

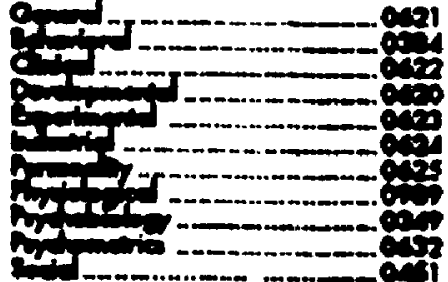

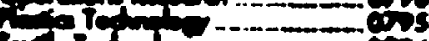


Thesis Acceptance Form

The underspgned recommend to the Faculty of Graduate Studies and Research acceptance of the thesis

\section{FEMINISM. POSTMODER NISM AND CONTEMPORARY C ANADIAN WRITING BY WOMFN}

submitted by Margaret Bricker. B.t

in partial fulfilment of the requirements for

the degree of Master of Arts

Chair. Department of

Carleton I niversity

September 13, 1996 
Hostonographic metafictoon is a postmodern writng practici which troubles the borders between genres. diccourses. disciphines. and epistemologic:s This thesis exammes the mtcrsection of femmot theory and postmodem atesthetlos in some recent Canadian historiographic metafiction by women the complevit! of any relationship between feminism and postmodemism is explored. as the polemics of opposition and alliance geve was to a position of negullation Interdiscursive negotiations are carried out at the junctures of histon and female subjectivit. in keeping with meta-feminust de- and reconstructronst agendas I feminist-postmodernist framework is thereby established. with which to explore the fiction-theon projects of Daphne Varlatt. Aritha van Herk. and Kristjalla

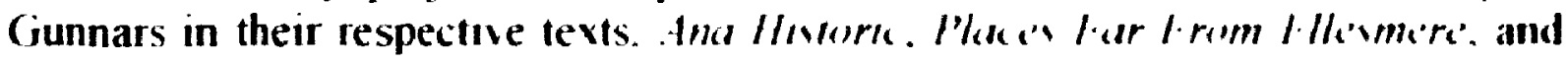
I he' Promler 


\section{Acknouledgements}

I bould like to thank Professon fernando de foro for his encouragement and gurdance. not only throughout the project but for the duration of my tudes at Casleton's school of (omparatise literan studies I would also like to thank Protessor Pat Smart for her insughtful comments and eding. and Professor Barbara (jabnel for her theoretical suggestions in the first chapter Man! thanks aloo lo Barbara Ihomas-Denyer for her admmstrative etforts on my behalf 


\section{Contents}

litle Pane

\section{Page}

Ihens deceptance tom

1

butract

11

lechnouledgement

III

('ontents

11

1

Introduction

(hapter I Vegoftatung Between $f$ emmom and Ponmodermom

Chapter 2 1 ritme (If Hotorical Representatums of temale

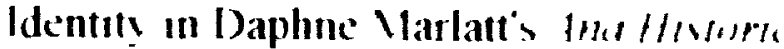

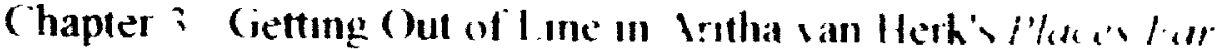

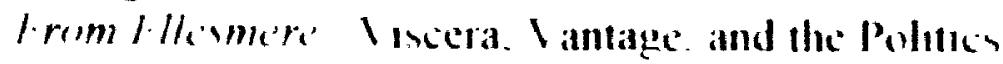
of cieografictone

Chapter 4 The Poetcs of Proulung and ( ind II ar II ntme in hristgana Cinnars' / he Promler

Chapters Alteratue (jenealogles

Biblograph! 


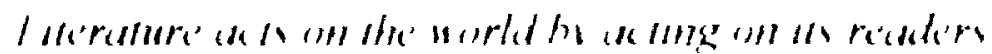

Patricinos Schweikat 


\section{Introduction}

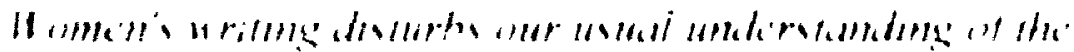

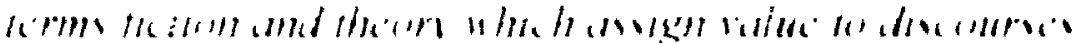

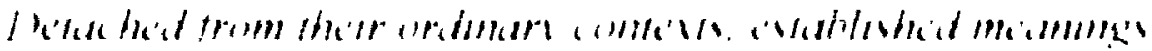

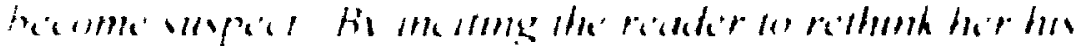

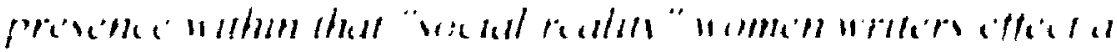

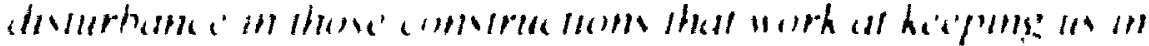

$$
\begin{aligned}
& \text { "ure "prepes" places } \\
& \text { - Barbara ciodand. "Fretion Theon ! ditomal" }
\end{aligned}
$$

Some of the recent wratmy bn ( anadian women that hat been germmantme: out of a preacommantl academic contevt. a paradigm comme to be hnown in

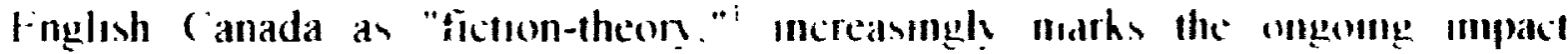
between femmst theoretical and postmodermst cultural practices I-iction-theon is a resistant writmg practice that disturbs the balance between fictoon and theon through an alıgnment of femmosm and posmodermism. II ordet "1o lum domuant discourses inside out" (de I auretis in Godard. 19860 th In the fiction-1heory br Canadian contemporanes Daphne Varlatt. Irutha van Herh, and Kristlanla Gunnars there is a similar politicization of how traditonal historical and literary discourses continue to delimit the representation of female idenlity and experience

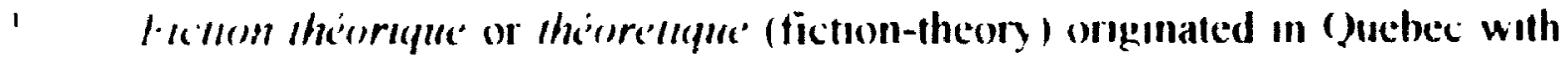
Nicole Brossard. who developed the term to describe a writmg practice at once feminist, political, and literary "the text as both fiction and theory - a theory working its way through syntax. language and even narrative of female as subject. a fiction in which theory is woven into the texture of the creation. eliminating or trying to. disunctions between genres, between prose, essay, poetry. between fiction and theory" (.Mezel, 1986b 7-8) While fictoon-theory "has been the dominant mode of feminist writing in Quebec for more than a decade" ( (iodard. 1986b. 5), fiction-theory is used here in an Iinglish (anadian context to signify,

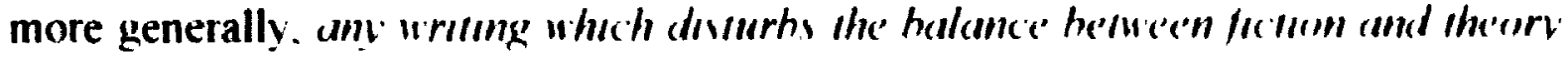
ithrough an alignment of femenism and pesimedernism 
In three dyamic lexts where lictoon and theon onertls collide in a strateg! of cultural tesstance. Marlatt. san Herh. and (iunnars engender aftematwe verstons of female sabjecturt in a new kind of femmst revsomst hostoncal fictoon that is politicaly. hustorically. and ethicall engaged

In "Resistmge Imnesa History and Personal life." Idrienne Rich identufies histon as the apoget of prolonged uneren power relations which contunues 10 define oul cultural moment "Histon is a was of justifing the hands that already bold the power. of prowng that others are unfit for power. In part by making imsusble or cruelly distortung their experience and culture" (198; 141) The discursive field of contemporan histenography. and its literany counterpart histonographic metafiction. hold out the potential for radical cultural transformation In the highly ambiguous and shifing ground between femmism and postmodernısm. historiographic metafiction offers a highly productive point of eatn and marks a privileged site of collision between history and fiction. the result of which is a demociatization of personal. political and historical discursivities. As a meta-genre which destabiluzes personal political. historical fictue dualities. histornographic metafiction proves fertile territory from which to begin to map the implicatıons of crossovers between femmısm and postmodernısm.

There is much contemporary debate surrounding the relationship between femmism and postmodemism: the polemics oscillate from optimistic calls for allance to omınous wamıngs for opposition. The question remains: where does 


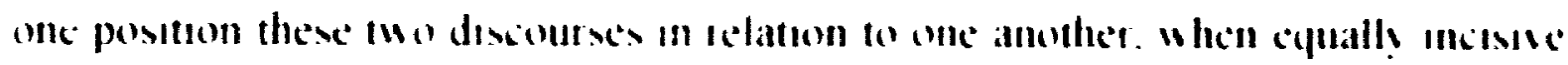

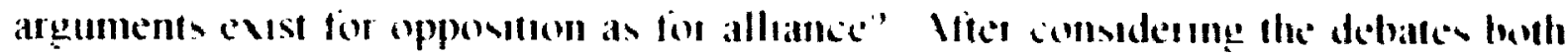

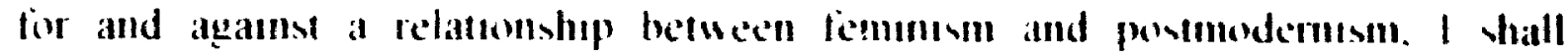

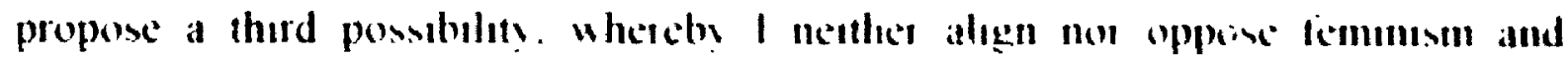

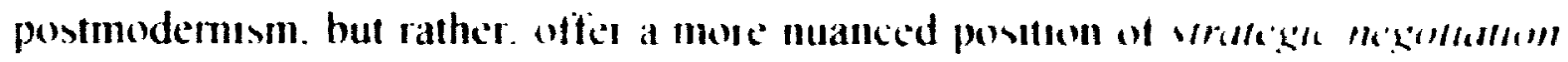
I arguc that there is room both theorsteally and pragmaticalls fine negonation between femmism and postmodernism. the objectise bemp to negentate an histoncally. politically. and therebs ethically, productece space hetucen the two discourses II hile I realise "ethical" is a high! subjectuce term. I define If fin the

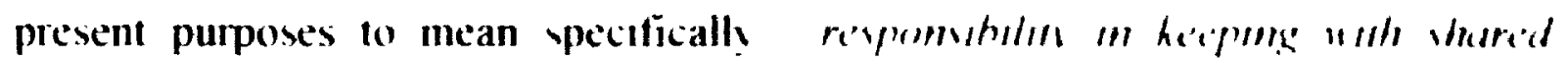

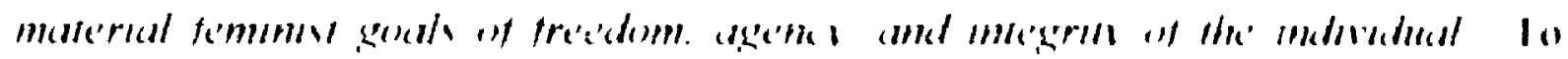
propose a negotiation between femmmsm and postmodemesm. onc which temams

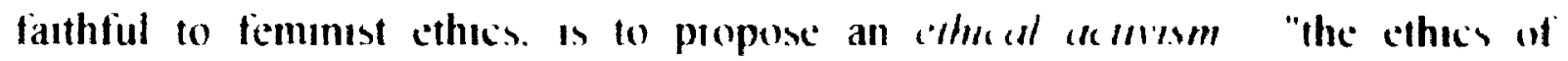
deconstruction and feminism is an ethical actusin which recumes that fudgements be made. yet which does not supply the means of legitumatıng those fudgements Vo recourse to self-p esent subjects, natural nghts. of transcendental truths " (I:lam. 1994 88) The ethical agenda I propose, then. is not founded on truth, but on temporary and contingent truths. what Flax terms political and ethical "responsibılity without grounds" (Flax. 1902. 458)

Negotiation is a strategy which muances between poutuons of alliance and opposition by attending to both points of overlap amel dissonance The agenda of 
thr- particular neqotrature project is to choose points of contact on the basis of political. hustorical and ethical responsibility I the tash at hand is at once personal. pollicical and academic it cutank imy own destre for a politncs of location. as well as all attempt to theorise a vable activist position from withn the disciplines of postmodernism and femmmsm. one which offers contextual responsibility both withın and without academia Howeves. a twofold academic and activist femmint-postmodemist agenda is not to disclaim the ultimate exclusivity of any relatıonship between femmmsm and postmodernısm: I take Straub's point that "[t]he conjunction of academic femınısm and postmodemist theory is. in the first place, an exclusive relatıonshıp between two fairly elite modes of discourse" (1991 283). lat the urgency of a feminist-postmodemist projest speaks for itself: in the nuncties alone. the publication of three substantial collections of essays (each of which greatly informs my own argument) - Vicholson's F'minsm f'osimodermism (1990). Butler's and Scott's Ie'mmiss /heorla' the Pellitical (1992). and Ferguson's

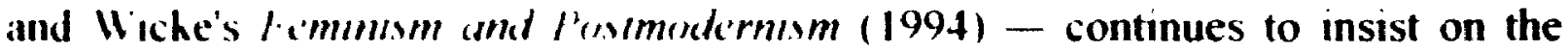
question of alliance or opposition. demonstrating that the task at hand, to locate interdiscursive openıngs between feminısm and postmodernism and transform them into a viable feminist-postmodernist position. remains relevant.

The "chosen pomts of contact and bonding" (hooks, 1995: 121) for my negottation between femınism and postmodernism are those of history and the construction and representation of female subjectivity. The postmodern "crisis" in 


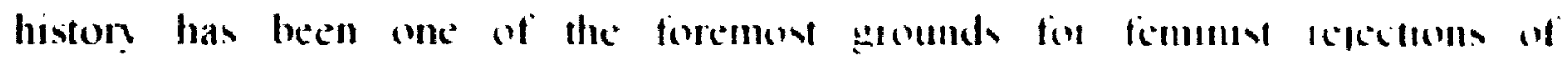

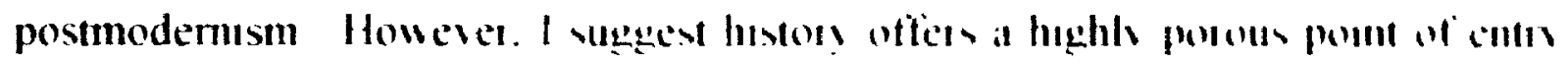
between the two discourses, whele femmmsm flegotlates the posmodem "aists" in histon into a politics of location for the subject History as both a thenctical discourse, demonstrated in the contemporan historiograply af Hayden Mlite (1978; 1984: 1987) and Dommich I al apra (1985). and as a literan discoulse. manifesting itself most overtly in that field of writing llutcheon terms historiographic metafiction (1985), provides a productuve silte fiom which to negotiate strategic inturdiscursive openıngs between femmism and posimodernısm iike history, female subjectivity has primarly been a site of opposition between feminism and postmodernism. While both postmodemms and fimm problematize Enlightenment notions of the Cartestan subject, the agendas for so doing differ dramatically feminsm critiques postmodernısm for its lach of gende considerations in its deconstructionist work on the subject. whereas postmodernısm opposes femmism's predilection for rearticulatmg the verw essentialist subjectivity that both postmodernism and femmısm work to subven a tendency, I might add, slowly being phased out of North American feminım duc to the increasing intersection of femmust theory with numerous other psychological, historical, and political theoretical discourses I argue for it contextualized and politicized subject position which negotiates between a feminist reconstructionist agenda of agency building identity polstics, and a 
postmodernist deconstructuonist agenda of decentering By politicizing the subject through a politics of location. we can use the decentered postmodernist subject as a strateguc agency building device for femınism.

Approaching the nexus of feminism and postmodernism from a contemporary ('anadian literary context, I explore the sites of history and female subjectivity through engaged readings of three texts in particular: Daphne Marlatt's Ana Hontork. Aritha van Herk's Ilacess far from l:llesmere, and Krostjana Gunnars' The l'rowler As no corpus is entirely random, I would like to acknowledge from the outset that these texts have been chosen for a number of reasons, first of which is their inclusion within the aforementioned fiction-theory paradigm. which is to say. texts produced primarily by feminist academic theoreticians under the dual signs of fiction and theory, feminism and postmodernism. As fiction-theory, these texts exhibit "a postmodern, self-reflexive, and personal form of writing which is informed by a feminist understanding of political and linguistic theory, and is characterized by wordplay, the deconstruction of genres. and the positing of a tenable female subject" (Kelly, 1995: 69). Second, Marlatt's, van Herk's, and Gunnars' texts are marked by a practice of poststructuralist poetics: a poetics which privileges a variety of resistant textual strategies including intertextuality. metafictionality, mise en ahyme, fragmentation. hybridization. indeterminacy, poststructuralist semiotics and language play, discontinuity, alinearity, and multiple perspectivism. Third, 
there is the obvious fact that all three authors are women. two of whom - Narlatt and van Herk - are recognized feminist theorists in the ( anadian milıeu Fourth. these texts are contemporary. each having been published in the past decade.

Finally, and perhaps most importantly for the purposes of this paper, the'xe three texts have been grouped together because of their similar metafictional

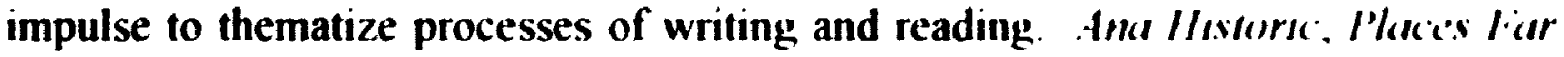
Irom Lllesmere', and The l'rowler juxtapose, in a highly self-reflexive and theoretical manner, the writing of (personal and official) history with the writing of fiction, and in so doing fall under the rubric of that meta-genre historiographic metafiction. I have chosen the field of historiographic metafiction mainly becausc it is writing which sits steadfastly, and yet precariously, at the border between the genres and disciplines of fiction, history, and autobiography, thus providing an overt problematization of the fiction/history, personal/political binaries and the so called "crisis" in history and epistemology ushered in by postmodernism.

As instances of both historiographic metafiction and fiction-theory, Arus Hestoric, Places liar lirom I:llesmere, and the l'rowler offer interdiscursive sites between postmodernism and feminism from which to transform the representation of female identity in such authoritative discourses as history and literature. My

2 By "official" history I mean the discourse of capital "H" History, as recorded archivally and accepted as the authoritative recording of the past; "personal" history signifies autobiographical or life writing at once personal political, and historical. Both discourses, I argue throughout the course of this thesis, are equally personal and political. 
readings will focus on how each text incites a re-evaluation of the rhetoric of "ctisis" linked to postmodernism - crises in the authoritative discourses of history, female subjectivity, literature, and epistemology - and the transformative implications of such "crises" for a feminist-postmodernist relationship heyond the polemics of opposition and alliance.

Structurally the thesis is comprised of five chapters: the first chapter establishes the feminist-postmodemist framework from which the subsequent three chapters, divided by author and comprised of readings of the primary texts, are contemplated. A concluding chapter then draws together the previous textual readings in a comparative manner.

Chapter 1. "Negotiating Between Feminism and Postmodernism," entails a re-evaluation of the relationship between feminism and postmodemism, beginning with a consideration of feminist critiques of postmodernism as ahistorical, apolitical, relativistic, nihilistic, immoral, and unethical. From an examination of the discursive nature of history through a reading of White and LaCapra's historiographic theory, I then take up a comparative analysis of feminist and postmodernist agendas regarding history and historiography, locating history as a viable crossover site between feminism and postmodemism. Subsequently, I move from the previous discussion of history and historiography to that of historir raphic metafiction. I briefly detail historiographic metafiction as a provisional term for that writing which overtly theorizes history as discourse, and 


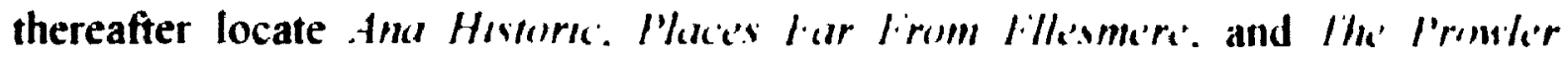
within the field of historiographic metafiction. My intention un this first chapter is to negotiate interdiscursive openings between feminism and postmodermism from the contexts of history and female subjectivity, the objective of which being to argue that a viable femimist-postmodermst agenda is historically, politically, and ethically possible. This chapter provides the theoretical framework from which to engage the texts in the subsequent three chapters.

Chapters 2 through 4 involve close theoretical readings of the primary texts from combined feminist and postmodernist theoretical and aesthetic frameworks. In Chapter 2, "Writing Off Historical Representations of Female Identıty in Daphne Marlatt's Ana Hestorrc," I consider how Marlatt's interdiscursive praxes of revisionist historicism and feminist critique work to rearticulate the representation of women in history. Chapter 3, "Getting Out of Line in Aritha van Herk's I'lace's Far lirom l:llesmere: Viscera. Vantage, and the Politics of Geografictione," shifts the focus from Marlatt's metahistoriographic project to a revisionist literary one. I focus on van Herk's movement within a particular "feminıst critique" paradigm, in addition to explaining how the popular postmodern metaphor for space, that of nomadology, figures as a trope for riconceptualizing female subjectivity. ('hapter 4, "The Poetics of Prowling and Cold War Writing in Kristjana (junnars' The Prowler," involves a contemplation of the prowling leitmotif as a complex trope for subverting literary, historical, subjective, and linguistic discourses. Since there 
is a curıous lack of feminist exploration of The lrowler. it having been contextualized primarily in terms of its poststructuralist poetics. I engage a femınist reading of the prowler figure as an openıng up of the sign of female subjectivity. While my primary readings are structured by the guiding metaphors informing each of the texts, they nonetheless converge through a common consideration of how each text thematizes interdiscursive spaces between femmism and postmodernism. The continuum along which each of my readings proceeds connects the ways in which the projects of Marlatt. van Herk, and Gunnars combine postmodernist metahistorical, metalingual, and metafictional strategies with feminist theory to disrupt historical, literary. and epistemological discourses, in order to make room for new articulations of female subjectivity. Finally, each chapter will consider the epistemological implications of the texts' feminist-postmodernist treatment of history and subjectivity, implications which invariably constitute, as we will see, a move towards perspectivism, or what Borsa terms a "politics of location" (1990).

The concluding Chapter 5 will provide a comparative consideration of the three texts, and offer some thoughts on the historical, political, literary, and academic implications of a feminist-postmodemist framework. as evinced in the projects of Marlatt, van Herk, and Gunnars. 


\section{Chapter 1: Negotiating Between Feminism and Postmodernism}

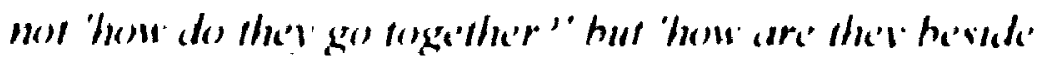

cacts osher"

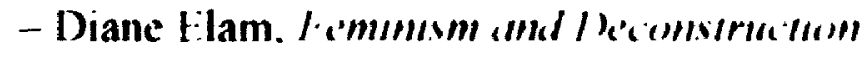

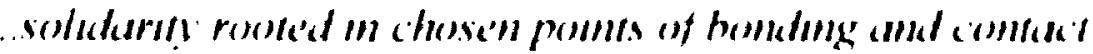

- bell hooks. "Representation and Resistance"

Any proposed relationship between feminism and postmodermsm. whether that of alliance, opposition. or a composite thereof, is necessanly compler The aim of this chapter is not to solve the tension, but to locate the multuple intersections between feminism and postmodemism. I begin with a consideration of both the points of contradiction and overlap. subsequently proposing that there is indeed room for negotiation between postmodemism and fe:ninısm. vis-a-vis the subject and history. As background to my own argument, I outhne frnedman's politics of negotiation and recuperation (1991). Haraway's theory of "situated knowledges" (1991), and Borsa's "politics of location" (1990) as three significant foundations for the negotiations I propose here. Before exploring the nexus of feminism and postmodernism, however, I will briefly contextualize my usage of those multifarious terms, postmodernism and feminism.

Postmodernism proves an elusive 'ism' which continues to evade any definitive chronological, linear or theoretical mapping. As the numerous volumes of essays devoted to finalizing just what postmodemism $a$ indicate, a neatly inked map with grid and timeline intact cannot be drawn. Instead, we can only construct 
for argument's sake a version of postmodernısm that suits the purposes at hand Postmodernısm is an umbrella term used to mark various discursive transformations that we are currently undergoing As an interdisciplinary cluster of discourses, postmodernism crosses historical. philosophical. theoretical, and cultural paradigms, ultimately existing "discursively, in the discourses we produce ahoum it and using it" (McHale, 1992: 1). The particular discourse I am concerned with here is neither postmodernısm as historical, social. or economic condition, nor as a paradigmatic. cultural or philosophical shift, the likes of which have been previously detailed by Lyotard. Jameson. Hutcheon, and Huyssen. amongst others. Rather. I engage postmodernism primarily as an aesthetics; an aesthetics of decentering. doubt, and deconstruction, the agenda of which is epistemological perspectivism." By epistemological perspectivism I mean that postmodernism works to uncover the constructedness implicit in any given discourse, effecting a move towards contingency, contextualization, and a politics of location, the latter of which involves contextual responsibility to "those places and spaces we inherit and occupy, which frame our lives in very specific and concrete ways" (Borsa, 1990: 36). Postmodernism in the context of cultural or aesthetic production signifies an iconoclastic discourse informed by poststructuralist poetics.

- I use 'deconstruction', 'doubt', and 'decentering' as synonyms to mean "any exposure of a concept as ideological or culturally constructed rather than natural or a simple reflection of reality" (Alcoff, 1989: 305).

1 Postmodernism and poststructuralism emerge from very specific and radically different historical contexts. Poststructuralism refers to the deconstructionis!, linguistic. and metatheoretical practices of a specific group of 
According to this definition of postmoderntsm as an acsthetes, postmodern writing is that which exhibits an! number of the following tevtual stlategues acite self-consciousness and self-reflexivity thematization of reading. writung and hermeneutical processes (metafictionality), an overt implication of the reader in the text. ontological and epistemological doubt. technical expermmentation. language play, a rejection of genre specific systems

The postmodern writing in which I am more specifically interested here is that marked by a radical problematization and thematization of the relationship between history and fiction. This area of literature, variously temed historiographic metafiction, metahistory, or revisionist fiction, marks the controversial site where the discourses of history and fiction meet and collide most overtly. It is here that most of the charges against postmodernism - charges of apoliticism, ahistoricism, and relativism - are levied, charges whose reverberations continue to affect other discourses, one of which is feminism.

Feminism is as heterogeneous and interdisciplinary as is postmodernism. and it has proliferated into an ever-growing network of discourses - crilual.

French intellectuals, and is not so much a 'position' as "a critical interrogation of the exclusionary operations by which 'positions' are established" (Butler and Scott, 1992: xiv); postmodernism is a diverse se $^{+}$of theoretical, philosophical, social, and cultural beliefs and practices of our period (for a thorough history and genealogy of postmodernism, see Huyssen's "Mapping the Postmodern" \{1993\}). Nevertheless, according to my contemporary mapping, poststructuralism is the critical counterpart to that more pervasive phenomenon, postmodernism. When I speak of postmodemism as an aesthetıcs, I refer specifically to poststructuralist poetics which underscore that aesthetics, or cultural practice, and use the two terms interchangeably in this sense. 
theoretıcal, phılosophical. psỵchological. lingustic, sociological. political. conomic. histoncist, and often a combination thereof Keepıng in mind that these femınısms vary widely according to their ideologies. goals. and strategies. I nonetheless offer Felman's definition as a direction from which to begin: "femınism as an enabling inspiration. not as a theoretical orthodoxy or as an authorızing new institutionalızation" (1994: 8). More specifically, the particular area from and with which I propose the following negotiations is one which ifor lack of a better word) I tentatively call meta-femmısm. A meta-feminist position is marked by a cross-fertilization of feminist political and ethical agendas (which 1

' I use 'meta' in conjunction with feminism to signify a feminism marked by inter- and intra-theoretical concerns. Meta-feminism is not to be confused with post-feminisin. though the terms are sometimes used interchangeably to signify a move hevond essentializing feminist discourses. which continue to invoke categories of sex and gender identities, and in so doing to replicate the very totalizing discourses meta-feminism seeks to subvert. Post-feminism is used to denote that period in feminism marked by a crisis in identity (Butler, 1990: 5), the 'post' invoked to emphasize its movement beyond essentialist feminist positions. The danger in using 'post', however, lies in its implication that feminism no longer exists (which would mean oppression and uneven power relations no longer exist), 'post' primarily signifying 'after'. The prefix 'meta', however, works in many of the same ways as 'post', but without the exclusionary implications: unlike post-feminism. 'meta-feminism' implies movement "between or among" in addition to "beyond or after" ((jage ( ancadian llictumary. 1983: 719). Saint-Martin outlines a meta-feminist position (in specific reference to recent Québec feminist writing such as that by Brossard) and differentiates between meta- and post-feminism as follows: "Pas plus que le métalangage ne tue le langage, le métaféminisme n'annonce le déclin du féminisme; plutôt. il l'accompagne et l'enveloppe. Le prefixe signifie aussi 'transformation', 'participation', comme dans 'métamorphose': sens heureux pour le féminisme, qui a toujours revendiqué l'ouverture au changement, aux voix nouvelles. Ainsi, les écrits métaféministes affinment autant leur enracinement que leur différence, suggèrent à la fois qu'ils vont plus loin et quils accompagnent. écoutent, tendent la main" (1994: 165). 


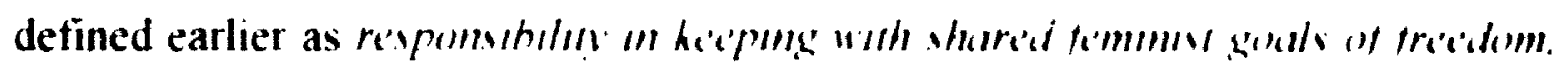
agencl: and integrin of the imdirdush) and postmodern poststructuralist textualities."

\section{A Strategl of Negotiation}

Having brefly outlined femmnsm and postmodernsm as they are used in the context of this thesis. I will now move on to a consideration of the two discourses concurrently While my intention is to negothate imterdiscursive openings between feminism and postmodermssm, my objective is not to collapse these diverse discourses into one another. in some valn attempt to narrate vet another homogenous super-discourse. Rather. I seek to locate what bell hooks calls "chosen points of bonding and contact" (1995 121) The strategy of my negotrations includes a consideration of both the points of cverlap as well as those places of resistance. and this is precisely where a position of negottation differs from that of alliance The 'and' serves an unportant marker, what Simger calls a "place holder". between postmodernism and femınım: it "keeps open a stle for strategic engagement" (Singer, 1992: 475). While I use 'femmnıst-postmodermust' to denote the product of my negotiation between feminism and postmodermism. I use

"A number of feminist discourses 1 am not including here under my 'meta-feminism' - essentialist. radical or various minority femınıst positions, for example - are far more dissonant with postmodernism than the academic meta-feminism I engage here, and in all likelihood far less negottable with postmodernism. 
a hyphen in place of the 'and' to serve as a hinge both connectung. as well as holdıng apart. femınısm and postmodernism

Analogues for describing the relationship between feminism and postmodernısm abound, and include marrage, conjunction. intersection, symbiosıs. reconciliatıon, compromıse, and "poolıng resources" (Singer, 1992 4681 " lach of these metaphors works to positıon feminism and postmodernism in a slighily defferent relationship I propose a strategy of megottanum, which works like Suleman's "mutual opportunism" (1992-322). Negotiation entails locating the intersections between femmısm and postmodernısm. and incorporating those points of contact (which function to form an enabling feminism) into a feminist-postmodemist framework. Negotiation is a crossover strategy that moves beyond binarial positions of opposition and alliance:

negotiation does more...than move back and forth between poststructuralist and nonpoststructuralist poles. more than weave the discursive threads together. more even than hold the contradictions in dialogic suspension -

Other critics would further tighten the relationship between feminism and postmodernism. however. Flax, for example, situates feminism as a type of postmodern philosophy: "feminist theory ...belongs in the terrain of postmodem philosophy. Feminist notions of the self, knowledge, and truth are too contradictory to those of the Enlightenment to be contained within its categories. The way(s) to feminist future(s) cannot lie in reviving or appropriating Enlightenment concepts of the person or knowlege" (1989: 54-55). While I agree that the proliferation of feminist discourses marked by a distrust of Western philosophy to explain human experience is indicative of postmodem plurality and doubt. I find Flax's move problematic mainly because it foregrounds feminist-postmodernist alliances and fails to attend to the equally important divergences between the two discourses.

" Mutual opportunism works through an integration of feminism's and postmodernısm's respective strengths and an elimination of their weaknesses in order to arrive at a postmodernist feminism (Fraser and Nicholson. 1990: 20). 
though it certainly does all these Vegotiation at this post poststructuralsst point in tume involses a commitment to self-consciously histoncizmg theor and theorizing histon (Friedman. 1991 481-2)"

What is more, negotiation works aganst "strategies of contanment" (llenderson. 1994 17) by acknowledging that one cannot rels upon or privlege an! one discourse to be accountable on every level - histonical, political. social, ethical. aesthetic. philosophical. or pragmatic - or to every community. nor to be enduringly 'true' For as Straub warns, while femminsm needs to open itself to other critical contexts to remain politically effective, femmism must also resist any imposed lımits that new analytic methods might bring (194) 28.3)" Interdiscursive Openings

Feminist critics, among others, question the general engagedness of postmodernism. particularly with respect to politics. history, and agency Postmodernism is charged with being apolitical, ahıstorical, and relativisitic for a number of reasons, some of which are convincing and others which are not I will next consider the complex interplay of uneasy points of divergence and cnabling

Negotiation, however, is not to be confused with the more popular 'recuperation', which Friedman differentiates as follows: "Ne'gencolum carries the double connotation of 'mutual discussion and arrangement' (as in negotiating a treaty) and manoeuvrıng to clear or pass an obstacle (as in negotiating a inountain pass). It also holds out in the way recuperation does not at least the possibility of mutual respect between equals" (1991: 481).

11 While Straub herself works in the juncture between feminism and deconstructionist theory, she reminds us to remain critical of the interdiscursive site: "Have we bought into a style that might limit us as much as, though in different ways than, the essentialist methodology we traded in? What can we do to resist those limits while still making use of the evidently valuable strategies of deconstruction?" (1991: 283). 
points of resonance between feminism and postmodernısm. The areas of impact between feminism and postmodernism which require immediate foregrounding and nuancing, are those of the subject and history

A central distınction between femınısm and postmodernısm, now somewhat dated, has been tha of practice versus theory feminism as activist and political versus postmodernism as academıc. However. while postmodernism was initially considered an intellectual, avant-garde aesthetics. postmodernist practices have now seeped into popular culture, most notably into the film and music industries." Conversely, femınısm, once an unınstitutionalized grassroots socio-political movement, has become institutionalized in academia. as the proliferation of Women's Studies programs and the study of feminist theory within Comparative Literature departments indicates. I therefore suggest there has been a gradual shifting of roles, effectively destabılizing any such academic activist dichotomy there may have once been between postmodernism and feminism."

"The enormous popularity this decade of such postmodemist films as Tarantino's I'ulp Fic/lon and Stone's Valurul Born Killers, for example, or of such musical genres as Hip-Hop or Rot (irrrls - all of which practice many previously avant-garde poetics such as hybridization, collage, pastiche, dialogism, heteroglossia. and parody - attests to postmodernism's movement from high to popular culture. Hip-Hop practices the heteroglossic art of sampling, an intertextual practice whereby excerpts of songs from different musical genres and periods and mediums. are layered one upon the other. Ruot ( irrrls could best be described as a meta-ftminist genre of music which inhabits a predominantly male-dominated genre - punk - in order to subvert constructions of women, female musicians in particular. from within the music industry.

1: Singer concurs by resisting what she terms the "facile distinction between feminism's political engagement and postmodernism's aestheticized selfabsorption" (1992: 470). 


\section{Repositioning the Giendered Subject}

The positioning of the subject and the ensung consequences for questions of agency has been a particularly uneasy point oi conflict between femmism and postmodernism. Feminism necessarily clashes with postmodernism over the latter's failure to take gender into account in its deconstructumst work on the subject. " Postmodernism's dismantling of the subject without attending to gender is certainly problematic for any feminsm. since gender is a major category of social organization. Gender "profoundly shapes and determmes subjectıvity |and| is an effect of complex, historically variable sets of social relations in and through which heterogeneous persons are socially organized as members of one and only one of an exclusionary and (so far) unequal pair - man and woman " (Flax, 199.3 97). Yet postmodernism's lack of gender analysis constuutes neıther an impasse nor grounds for dismissal, as some feminist critics would have it Rather, femmst gender analyses offer many insightful implications for postmodem concepts of subjectivity.

A feminist-postmodernist positıon is mutually opportunistic just as postmodernism provides feminism with political and critical possibilities for escaping essentialist subjectivities, so does feminism radicalize and politicize the

$17 \quad$ While I am limiting my consideration primarily to that of gender, there are a number of equally important specificities that postmodernism fails to consider in its deconstruction of the subject: race, ethnicity, class, color, and sexual orientation to name a few. Some of these identity markers do come into play in chapter three and four, however, with Marlatt's and Gunnars' texts. 
postmodem subject with gender considerations (Waugh, 1996: 362). As Hutcheon points out, feminism in fact changes the very direction postmodernism was going (Hutcheon, 1986b: 219). Similarly, Suleiman posits that a feminist-postmodemist position provides postmodernism with "a concrete political edge, or wedge, that could be used to counter the accusatory pessimism of a Baudrillard or Jameson" (1992: 321). Feminist intervention into the postmodern subject position would entail a move within and beyond postmodernism's discursive boundaries (and beyond an 'accept/reject' position), allowing the subject to remain an open site for negotiation. By supplementing postmodernism's deconstruction of subjectivity with particular attention to constructions and deconstructions of gender, a diffusion thereof - what I term a feminist-postmodernist position - emerges that moves beyond binaries of alliance/opposition, essentialism or nominalism, to a third position of negotiation.

Agency

The long-standing debate over the complex relationship between social identity and political agency further continues to set feminism and postmodernism in opposition, and requires some negotiation. The postmodern subject needs contextualization within its own discourse before it can function as an interdiscursive opening with feminism. Theorizing the subject from a postmodemist poststructuralist framework substantiates a shift from the hegemonic discourse of the unified "I" to a dispersion of the subject into multiple 
subjectivities. ${ }^{14}$ The decentered subject of postmodernism is itself "dependent for its inception on a rather elitist set of conditions and applicable, as a theoretical tool, in some, not all. class-, race-, and gender-determined circumstances" (Straub. 1991: 278). This means that politicizing the subject through a strategy of decentering is not a productive strategy for all feminist projects at all times. In "'Circling the Downspout,"' for example, Hutcheon articulates how challenges to the coherent, autonomous subject have to be put on hold in [some] feminist and post-colonial discourses, for both must work first to assert and affirm a denied or alienated subjectivity; those radical postmodern challenges are in many ways the luxury of the dominant order which can afford to challenge that which it securely possesses (151).

Granted feminism needs to continue affirming various subject positions in order to realize specific political goals in the name of women, it is nevertheless necessary "to be constantly aware of the dangers of fixing subject positions and meanings beyond the moment when they are politically productive" (Weedon, 1987: 172).

Flax makes an important contribution to the debate which further troubles the tensions between feminism and postmodernism, that being that white Western feminists have also colluded with Enlightenment philosophies, and are in as much need of divestment as other privileged (read white, male) Westerners:

I do not read postmodernism as a narrative about the identity crises of a few, relatively privileged contemporary Western white men. Despite our marginalization by them, white Western feminists are not situated completely outside the belief systems postmodernists question. How would we be, since it is a dominant strand in contemporary Western cultures? However marginalized we may be by and within these cultures, white

14 For a discussion of Enlightenment conceptions of the subject and other metanarratives of truth, reason, and knowledge, see Flax's INesputed Subjects (1993). 
women are also beneficiaries and products of them. There are many ways in which white feminist discourses are dependent upon and participate in maintaining Enlightenment hopes (1993: 30).

Mainstream white academic feminism in particular cannot afford to reject postmodemism's important political move of recognizing the cultural construction of the subject; to deny this, as essentialist feminist positions do, is to rearticulate a homogenizing and oppressive subject position in the name of 'woman'. 's

Identity politics are by nature prescriptive, oppressive, factionalizing and exclusionary, and need be reconciled $\mathrm{i}, \mathrm{h}$ an equally important goal of feminism: "to emancipate [the subject] from the maternal or racialist ontologies to which it has been restricted, and to give it play as a site where unanticipated meanings might come to bear" (Butler, 1992: 16, my italics). To deconstruct the subject is to open it up, rather than close it, to multiple contingencies and potentials for agency.

If feminists fail to learn postmodernism's lesson of the deconstructed subject, feminism may relapse into the very totalizing discourses it seeks to displace. Butler asks us to consider the consequences of an essentialist position:

If there is a fear that, by no longer being able to take for granted the subject, its gender, its sex. or its materiality, feminism will founder, it might be wise to consider the political consequences of keeping in their place the very premises that have tried to secure our subordination from the start (1992: 19).

1" The "disabling vestiges of essentialism" in feminist theory to which I refer are theories of biological determinism: the supposition that there exists a biologically-based female essence that serves as the primary marker of difference between men and women, one which manifests itself in language and writing (Fraser and Nicholson, 1990: 20). 
I therefore maintain that a feminist-postmodernist destabilization of the subject is highly political and "establishes as political the very terms through which identity is articulated" (Butler. 1990: 148).

Much has been made of the untimely deconstruction of the subject as a neo-colonial and neo-patriarchal conspiracy by Western mainstream academics to undermine white women, women of colour, and other oppressed groups' emergence into arademic and artistic milieus. As hooks, Gates. Hutcheon. and Culler amongst others note. the destabilization of identity constructions is a precarious political move that "may be strategically empowering...oppressive' as well as energizing" (Culler, 1992: 220-21, my italics). While numcrous critics have rightly questioned the "coincidental" deconstruction of the subject with the growing agency and profile of oppressed groups, we must also consider how postmodernism, a condition of doubt and suspicion, has helped generate the very climate out of which various counterdiscourses have arisen. Therefore, we can transform this "coincidence" into an agency building strategy which effectively politicizes the very (racist, sexist, hierarchical) epistemologies on which identities are formulated: "the critique of identity may be less a ploy of domination than a contribution to the politicization of identity and a contribution also to possibilities of resistance to the identities leaders construct for those they would lcad" (c 'uller, 1992: 220). ${ }^{16}$ The radical critical and political possibilities of moving beyond 16 For arguments along these lines, see hooks' "Postmodern Blackness" (1990), Gates' "The Master's Pieces" (1991), Hutcheon's "'Circling the Downspout 
essentialism for all women and all oppressed groups entail escape from "static over-determined identity within mass culture and mass consciousness." a move which offers "new possibilities for the construction of self and the assertion of agency" (hooks, 1990: 28). Butler stresses the agentic qualities of the multiplicitous subject: "rifts among women over the content of the term [women] ought to be safeguarded and prized...this constant rifting ought to be affirmed as the ungrounded ground of feminist theory" (1992: 16, my italics).

Postmodernism verges on the apolitical predominantly because of its duplicitous nature; it functions paradoxically as both a metatheoretical and an historically and politically engaged paradigm, implicating itself in the very discourses it seeks to subvert. The postmodernist aesthetics of doubt offers no stable alternative paradigm in place of the ones it seeks to undermine; instead. postmodernism remains a deconstructionist discourse whose very existence depends on the persistence of other authoritative, truth-making paradigms. Postmodernism is thus a "strange kind of critique" whose duplicity and complicity hold the potential for "a new engagement with the social and the historical world...done in such a way as to challenge (though not destroy) our traditional humanist beliefs" (Hutcheon, 1988a: 1-2; 1989a: 4). That postmodemism threatens to diffuse, if not preclude, the political agendas of marginalized groups is a very real concern. The feminist apolitical and relativistic arguments against the Empire": Post-Colonialism and Postmodernism" (1986), and Culler's "Literary Theory" (1992). 
postmodern displacement of the subject maintain that without a strong foundation on which to advocate agency, there can be only relativism:

the postmodernist project, if seriously adopted by feminists, would make any semblance of a feminist politics impossible. To the extent that feminist politics is bound up with a specific constituency or subject. namely. women, the postmodernist prohibition against subject-centered inquiry and theory undermines the legitimacy of a broad-based movement dedicated to articulating and implementing the goals of such a constituency (Di Stefano: 1990: 76).

However, there is room for negotiation between feminism and postmodernism at this precarious political juncture if one concedes, as I do, that this position's foundational premise - the equation of the loss of a stable subject position with the loss of agency - is weak. To acknowledge the constructedness of identity is not to preclude agency for women; the fundamental problem with this reasoning is the equation of constructedness with ineffectivity: that "constructedness" has come to mean "unstable" is a mon sequitur (Gates, 1991:

113). Indeed. construction and agency can be easily misconstrued:

Construction is not opposed to agency; it is the necessary scene of agency, the very terms in which agency is articulated...the critical task for feminism is not to establish a point of view outside of constructed identities; that conceit is the construction of an epistemological model that would disavow its own cultural location and. hence, promote itself as a global subject, a position that deploys precisely the imperialist strategies that feminism ought to criticize (Butler, 1990: 147).

In terms of female subjectivity, a feminist-postmodernist position offers a contingent and contextualized subjectivity that emerges "paradoxically within the very decentring of the subject" (Godard, 1989/90: 140). The apolitical critique of postmodernism is further troubled when one puts pressure on the notion of the 
political itself. Elam proposes an "abyssal politics," a "politics of undecidability" wherein political action based on a stable subject and universal laws is replaced with a politics based on "ethical activism" and "groundless solidarity":

the politics of the undecidable is an insistence that we have to make a decision, each time, in each case...we have to learn to negotiate outside the horizon of authority. No more authoritative deconstructions of literary texts, no more authoritative statements on the essence of woman. To speak without recourse to the m.eta-language of authority is to speak as singularities, to attempt to do justice in singular cases, rather than just once and for all...the politics of undecidability must...engage with ethics and consider ohligatoons and responsihalities (1994: 87,120).

While postmodernism offers no activist political agenda outside of a deconstructionist aesthetics of ideological doubt, the political and historical responsibility postmodernism does offer feminism is a problematization of historical, literary, subjective, and political discourses themselves. discourses which continue to marginalize women. A feminist-postmodemist position allows a move away from essentialism as a source of agency to that of provistonalism, or a politics of location, while still retaining agency for feminist subjects. Hooks refers to this as a posimodernism of ressstance, wherein "culturally and historically specific contexts are not lost in the face of an abandoned essentialism" (1990: 30-31). Politics and agency are possible without identity politics and an essentialized subject. The contention between feminism and postmodernism regarding the subject and agency transforms into a site of negotiation through an infusion of feminist and postmodernist positions into that of "antifoundationalist coalition politics" (Butler, 1990: 16) and "groundless solidarity" (Elam, 1994: 
120), both of which stress "a deferral of consensus but $m$ ot at the cost of polittial solidarity or ethical judgement" (Elam. 1994: 25). The result is a poluties and agency based not on identity but on solidarity: a "coalitıon bult around a suspicion of identity as the essential grounding for meani:ggful political actoon" (Elam, 1994: 69).

\section{Feminist and Postmodernist Agendus}

Consideration of the gendered, deconstructed subject and its agency-building potentialities leads to a third area of umpact between femmmsm and postmodernism: their respective agendas. Postmodernısm is primarily deconstructionist by agenda, and works to expose the ideological nature of any given discourse. Feminist agendas vary widely, but meta-feminısm's agenda is both deconstructionist and reconstructionist, and works in a postmodernist way to undermine the represe ation of women in dominant discourses, as well as to open up, or reconstruct, new and multiple possibilities of female subjectivity. The agendas of poststructuralist feminism and postmodernism thus overlap in their deconstructionist impulse "to distance us from and make us skeptical about beliefs concerning truth, knowledge, power, the self, and language that are often taken for granted within and serve as legitimation for contemporary Western culture" (Flax, 1989: 54). While both meta-feminism and postmodernism aim to expose the ideological nature implicit in all philosophical, historical, politucal, and social 
constructions of knowledge and power, feminism's agenda is primarily reconstructionist:

feminist theory is not only a movement of critical opposition of the false universality of the subject, it is also a positive affirmation of women's desire to affirm and enact different forms of subjectivity. This project involves both the critique of existing definitions and representations of women and also the creation of new images of female subjectivity (Braidotti, 1996: 411). ${ }^{17}$

Feminism has distinct social and political goals that surpass "postmodern limits of deconstructing existing orthodoxies" (Hutcheon, 1989b: 150). While postmodernism criticizes systems of power and knowledge, it refrains from refilling (even temporarily) the emptied cultural suitcase. ${ }^{18}$ Keeping open this fundamental difference between feminism's and postmodernism's respective agendas, I nevertheless suggest a feminist-postmodernist agenda which works in a continuum between de- and reconstruction and, as such, is neither relativistic, apolitical, or essentialist.

Haraway and Friedman offer feminist-postmodernist positions that incorporate both the postmodern agenda of problematization and the feminist

"A reconstructive agenda vis-à-vis the subject is not to be confused with a position of essentialism: "the concept of posıtımalsty allows for a determinate though fluid identity of woman that does not fall into essentialism: woman is a position from which a feminist politics can emerge rather than a set of attributes that are 'objectively identifiable'. Seen in this way, being a 'woman' is to take up a position within a moving historical context and to be able to choose what we make of this position and how we alter this context" (Alcoff, 1989: 325, my italics).

18 The metaphor of the cultural suitcase nuances between meta-feminist and postmodemist de- and reconstructionist agendas: if postmodernism entails a continual unpocking of the cultural, social. political, and historical suitcase, feminisms entail both an unpacking and various re-packıngs, however provisional. 
reconstructionist and recuperative agendas of agency They open up a politically and historically engaged dialogue between postmodemism and femm!nsm through a politics of location, contextualization and accountability

Positioning implies responsibılity $I$ am arguing for politics and epistemologies of location. posttioning, and situating. where partiality and not universality is the condition of being heard to make rational hnowledge claims (Haraway 1991: 193-5)

Friedman proposes a renegotiation of those constructions postmodermisin undermines - namely. identity and agency - through a poetlos she terms "post/poststructuralism," whereby identity is maintained but in a consciously tluid. constructed, and ever contradictory state (1991: 472)." Post/poststructuralism's agenda is political engagement. "The question of 'femunist engagement' at this post/poststructuralist moment forces us to ask anew where and how we can be politically engaged as academic feminists" (Friedman, 1991: 468-70). Frnedman's post/poststructuralism is a theory of responsible feminist poststructuralism: "feminist criticism as the avant-garde of a shift toward a 'responsible' poststructuralism" (Friedman, 1991: 477).

Similarly, Haraway asks us to envision a politics which can encompass the dispersed subject: "What kind of politics could embrace partial, contradictory, permanently unclosed constructions of personal and collective selves and still be faithful, effective - and, ironically, socially feminist?" (1990: 199). She

11 Friedman's use of the double "post" in order to signal a responsible feminist poststructuralism is unnecessary; I prefer to simply use "feminist-postmodernist" to describe the product of a negotiation between feminism and postmodemism. 
reformulates key terms problematızed by postmodernism - the subject. knowledge, objectivity - through what she calls "situated knowledges":

feminist objectıvity means quite simply situated knowledges. [and] is about limited location and situated knowledge, not about transcend ise and splitting of subject and object. In this way we might becone uswerable for what we learn how to see (Haraway, 1991: 188, 190).

Haraway's proposed objectivism is a negotiation between feminism and postmodernism: "a doctrine and practice of objectivity that privileges contestation. deconstruction, passionate construction, webbed connections, and hope for transformation of systems of knowledge and ways of seeing" (1991: 191-2). Moreover, Haraway repositions the singular subject with that of the multi-perspectival one: "the opening of non-isomorphic subjects, agents, and territories of stories unimaginable from the vantage point of the cyclopean, self-satiated eye of the master subject" (1991: 192). As both Haraway and Friedman suggest, a feminist-postmodernist position underscores contextual responsibility - responsibility for one's social, political, and historical location the result of which is a politics of location.

\section{From Problematization to Democratization}

Postmodernism is critiqued as relativistic and politically ambivalent because of its singularly deconstructionist agenda and its attendant aesthetics of doubt. As a discourse which problematizes, but allows for the discovery of new, situated truths (negotiated spaces from which to speak), postmodernism's indeterninacy is not about relativism or nominalism. but about "refusing to ground 
decisions in universal laws" (Elam, 1994: 87)." While postmodemism is an anti-foundational discourse. advocating perspectivist ideologies and situated knowledges, it "does not entail the position that there are no solutions to epistemic dilemma, merely that there are no final ones" (Nicholson, 1994: 84-5).

Flax effectively diffuses the relativistic argument against postmodemism with her observation that "relativism only takes on meanıng as the partner of its binary opposite - universalism... If the hankering for an absolute universal standard were absent, 'relativism' would lose its meaning and force" (flax, 1992: 452-3). The long-standing question remains whether problematization is politically inert. and whether problematization impacts political and social realities. Yet it seems obvious that problematization is a political strategy in and of itself: it works to question existing systems of power and knowledge and uncover their attendant ideologies - "The very orientation of postmodernism to the agentic quality and features of our sociocultural worlds underlines the significance of this political-ethical project" (Yeatman, 1990: 291) - without the epistemic arrogance of presuming to know any truths to put in its place. It is in this sense that postmodernism has been considered "democratic egalitarianısm" (Mc(iowan, 1991: 29).

21) I use 'deconstruction' according to tlam's definition: "a questioning of the terms in which we understand the political, rather than as a simple negation of the political" (1994: 67). 
Subject positıonality and ensuing questions of agency and agenda are some of the ambiguously conflictual and conciliatory areas where feminism and postmodernism impact, and in so doing need remain open as contestatory and enabling sites of contact:

leminist theories, like other forms of postmodernism, should encourage us to tolerate and interpret ambivalence. ambiguity. and multiplicity as well as to expose the roots of our needs for imposing order and structure no matter how arhitrary and oppressive these needs may be. If we do our work well, 'reality' will appear even more unstable, complex, and disorderly than it does now (Flax, 1989: 73).

A project of interdiscursive negotiation, or what can be variously termed "strategic perspectivism" (Alcoff, 1989), "nomadism" (Bratdotti. 1996). "perspectivist ideologies" (Nicholson, 1994), "situated knowledge" (Haraway, 1991). "political heterogeneity" (McGiowan, 1991), "permanent partiality" (Hardıng, 1986) or a "politics of location" (Borsa. 1990; Braidotti. 1996; Haraway. 1991), entails the development of countergenealogies: alternative localized and contextualized theories of the subject. history, and epistemology. If postmodernism is "potentially enabling yet resisting" by nature (West, 1989: 96), at times illumınating for femınism while at others removed from feminism's ethical activist goals, a negotiative strategy entails incorporating those aspects of postmodemism that are accountable to feminist goals into a hybridized feminist-postmodernist framework Yet without a strategic intervention into and negotiation with postmodernism. at the sites of both divergence and convergence, academic feminism will lose much ground and relapse into a rearticulation of the very 
totaliong. essentiali/my discoures 11 sceks to werluth if we accept the postmodern progect's agenda to be one of perpetmally andonng. Wall an altendallt

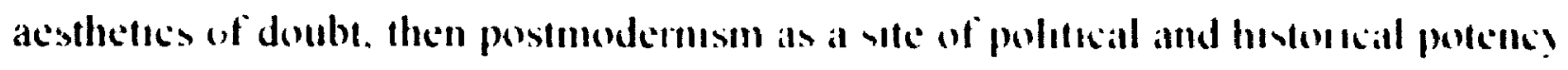
becomes highly relevant when combuned with femmon

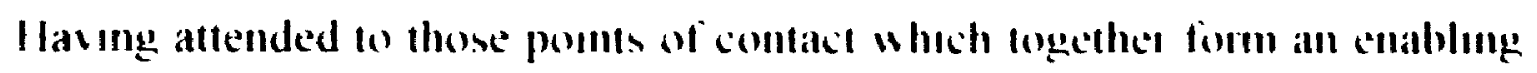
femmist-postmodemist positnon. we in keepme with political ethical goals of contextual respensibility and a polatic of location. I now mone on to a consideration of history as another highly enabling pount of bondeng

\section{Contemporary Hisforiography.}

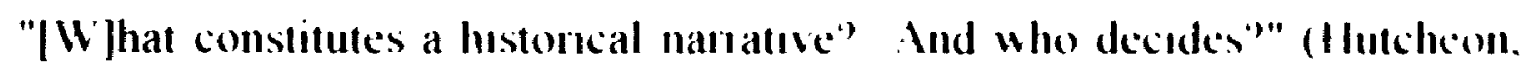
1989a: 16()). The postmodern "crisis" in history. Lhe that of the subject. has been one of the foremost grounds for femment dismessils of posmondemism Ihis wo called crisis in historicity that postmodem hostoricism has come lo stgmal incorporates a move fom history to metahıstory. metahistory heomp "a process of double reflection. twice-removed from the ostensble object of the histonan's quest" (LaC apra, 1985 45-6).

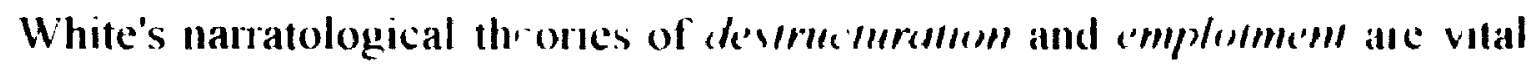
to contemporary historiographic theory. which relativises history as a disculsive and an ideological construct. 'Destructuration' describes the process of de- and re-codation of events or happenings from one nartative mode to another (1078 96). 'Emplotment' entails a similar process whereby 
events are made into a story by the suppression or subordination of certain of them and the highlighting of others, by characterization, motific repetition, variation of tone and point of view, alternative descriptive strategies, and the like - in short, all of the techniques that we would normally expect to find in the emplotment of a novel or play (White, 1978: 84).

White's theories of destructuration and emplotment illustrate the rhetoricity of history. LaC'apra, moreover, proposes a perspectivist historicism which negotiates between over- and under- contextualization, between objectivism and subjectivism, and between subjectivism and total narcissism:

a more interactive model of discourse that allows for the mutual - at times mutually challenging - interchange of 'documentary' and 'rhetorical' dimensions of language may further a broader conception of historical knowledge itself - one that gives a new twist to the venerable idea that history is both 'science' and 'art' (1985: 21).

The contemporary postmodern historiography of White and LaCapra illustrates how history, like fiction, is a system of meaning production; one which constitutes rather than reflects or explains, its subjects The narrative deconstruction of history as a recording of the "actual" or "real" by contemporary historiographers LaCapra and White becomes highly significant for feminists, who can utilize this new concept of historical perspectivism to critique and politicize the historical production of women.

Contemporary historiography is marked by a postmodern "crisis" in Westem epistemology, the implications of which are a provisionalization, and thereby democratization, of history as discourse. Postmodernism is often critiqued as ahistorical, yet the contemporary historiography it espouses does not entail a 
move away from history. but a move towards me'lahistory. In metahistory there is a general understanding "that historians constitute their subjects...by the very language they use to describe them" (White. 1978: 95). Iike the feminist-postmodernist subject and its radical implications and potentials for agency and politics, this postmodernist "New History" (Lindenberger. 1990) becomes a question of perspectivist ideologies and standpoint epistemologies (a move from history to histories), and as such, remains politically and historically charged. ${ }^{21}$ Contrary to feminist charges of ahistoricism. postmodern historicism marks a politicization of the historical: "The historian's traditional search for 'the' story is often replaced by an acknowledgement of multiple stories, each one of which reflects the hermeneutics of the critic-as-narrator" (Friedman. 1991: 48.3). The contextualization of history as discourse does not result in historical relativism (in the sense of nominalism or nihilism), for much the same reason that the deconstrucied subject does not preclude agency and politics: objectivism and relativism are false alternatives. Rather, history is recognized as dialogical and contingent, a discourse in which the historian "enters into a 'conversational' exchange with the past" (LaCapra, 1985: 36). Postmodern historiography politicizes and democrallzes history by foregrounding history's discursive structure:

21 This is not to generalize that all postmodernisms are politically and historically engaged, however: Baudrillard's theories of hyperreality and the simulacrum, for example, deny any tangible reality outside of its representations and as such, are highly apolitical and ahistorical (1993). 
postmodern writing brings a sort of equalization of knowledge, where no longer are we able to believe in, or even accept that there are 'superior' types of knowledge, since once we begin to deconstruct each discursive practice, we finally discover that at the beginning and at the very base of each discipline and branch of knowledge there is a fundamental assumption, unprovable, unverifiable ("the proof of the proof") on which the whole system has been erected (de Toro, 1994: 437).

How feminism and postmodernism engage history, often argued to be an area of divergence between the two, ${ }^{22}$ is thus a productive site of convergence from which we can theorize a viable feminist-postmodernist position. It is precisely postmodern historiography's movement along a continuum of objectivity and subjectivity, rhetoricity and referentiality, that marks its critical and political possibilities for feminism. Postmodern historicism's negotiation between objectivity and subjectivity concurs with Haraway's "situated knowledges" (1991) and Friedman's "subjective objectivity" and "post/poststructuralism" (1991), all of which stress historical perspectivism and a politics of location. Feminism can incorporate the postmodem historiographic crisis in history into an agency building strategy for historicizing and rehistoricizing the subject of its own discourse - woman. Postmodern historicism incites necessary "attention to historical specificity in the production, for women, of subject positions" (Weedon, 1987: 135). In addition. postmodem historicism's radical contingency enables feminism to escape from epistemological hierarchies through contestation of : Feminist critics have argued that history is the grounds on which a political activist feminism need rest, yet every discursive site, history included, need remain open to investigation if we are to truly escape foundationalism: to refuse rigorous contestation is, as Butler has noted, "to sacrifice the radical democratic impetus of feminist politics" (1992: 16). 
"official" interpretations of history. Contemporany historiography's antifoundationalism, futhermore. enables feminism to avoid essentialist traps and thereby remain vigorous in its attention to ideological underpinnings within and without its own discourse:

If feminism cannot be political without assuming history as its foundation. then the very notion of history that is the foundation cannot be subjected to historical inquiry. The 'history' that functions as a foundationalist premise is thus radically dehistoricized, and the postmodernist who puts this foundation into question turns out to be more radically historicist than the foundationalist historian (Butler, 1994: 234-5).

\section{Historiographic Metafiction}

Historiographic metafiction is a provisional term for that writing which overtly theorizes historiographic and literary theory. ${ }^{27}$ It is a hybrid genre which incorporates the contemporary historiography I have just outlined, with that of postmodern metafictionality. Metafiction refers to self-reflexive writing which theorizes its own processes and its own discursivity, working "simultaneously to create a fiction and to make a statement about the creation of that fiction" (Waugh. 1984: 6). ${ }^{24}$ As such, metafiction is a productive site from which to mark the impact of feminism and postmodernism:

${ }^{23} \quad$ Historiographic metafiction can been alternately termed 'revisionist history.' 'fictionalized history.' or "istorical fiction'. I use historiographic metafiction throughout for the sake of slarity and consistency.

24 Note, however, that there are varying degrees of metafictionality as there are of postmodernism, ranging from those which problemaise and politicize to those which function as nihilistic ventures into hyperreality: "there are two poles of metafiction: one that finally accepts a substantial real world whose significance is not entirely composed of relationships within language; and one that suggests there can never be an escape from the prison house of language and either delights or despairs in this" (Waugh, 1984: 53). The metafiction I am interested in here is 
it is situated at the borderline that separates art from life, signifiers from signified, possible worlds from the actual world. Metafictional texts underline the self's possibility of transgressing those borderlines in an analytical, playful way that involves its authors and readers (Gheorge. 1991. 46).

To combine a consideration of history with metafiction, as historiographic metafiction does, is to reflect upon the processes of history-making alongside those of fiction-making. This hybrid genre of history and fiction writing balances precariously between historical and fictive discourses, genres, and disciplines. Historiographic metafiction is a postmodernist writing which conflates the writing of history with that of fiction, whereby history is shown to be a construct, but a necessary construct, for which the historian must take contextual responsibility. The rhythm of historiographic metafiction is paradoxically de- and reconstructionist: it stresses the importance of history at the same time that it problematizes historical knowledge in gereral, and as such is "made the means to a m'll' engagement with the social and historical world" (Hutcheon, 1988a: 1-2, my italics).

Positioned at the crossroads of historical and fictive discourses, historiographic metafiction undermines ahistorical and solipsistic critiques of postmodernism. Historiographic metafiction pre' '? matizes history, but not at the cost of denying the "real". It does not claim that the past did not occur, or even that it is inaccessible for that matter; rather, historingraphic metafiction implies that epistemological perspectivism is the groundless ground of all histories. Once that grounded in the empirical world. 
again. we must differentiate between problematization and denial if we are to consider historiographic metafiction as an interdiscursive opening between fetninism and postmodernism As Hutcheon points out.

The act of problematizing is, in a way. an act of restoring relevance to something ignored or taken for granted. The 'real' thing has... had a problematic relation to art ever since Plato. What postmodernism does is not only to remind us of this, but also to investigate our amnesia (1988b: 229).

As a site of impact between history and fiction, historiographic metafiction is a highly theoretical writing whose implications reverberate to various other discourses, one of which is feminism. By signaling history, like fiction, to be an ideological construction, historiographic metafiction provides feminism with the grounds from which to contest constructions of "official" histories, like women's for example. That historiographic metafiction politicizes history by effectively underscoring the provisional nature of any historical story, is highly productive for feminist goals of reconsidering various histories from locations other than the center. What is more, historiographic metafiction contests what is for feminism an uneasy division between the personal and political; just as boundaries between history and fiction are transgressed, so dn personal and official h, dorles collapse, one into the other:

In granting new and emphatic valus in the notion of 'experience', femınisms have also raised an issue of great importance to postmodern representation:

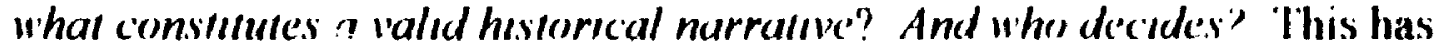
led to the reevaluation of personal or life narratives - journals, letters, confessions, biographies, autobiographies, self-portraits... If the persona is political, then the traditional separation between private and public history must be rethought...life writing and its politicization of the personal is the 
kind of work that sits on the borderline between fiction and personal history (Hutcheon, 1989a: 160-61, my italics).

Therefore, I maintain that historiographic metafiction's epistemological and historical perspectivism intersects with feminist ethical activist goals, one of which is to affirm very real histories such as those of women's oppression.

The projects of Marlatt, van Herk, and Gunnars are situated at the interstices of postmodernism and feminism. In reading Places frar from lillesmere, Ana Hostoric; and The Prowler from the intersecting frames of postmodernism. feminism, and contemporary historiography, we see the emergence of counter-histories and counter-subjectivities. Through postmodernist techniques of metafictionality. metahistoricism, and other poststructuralist strategies for dismantling traditional narratives and epistemologies, theirs are texts which insist on questions of history, and which effectively reconceptualize the female subject, in keeping with feminist ethical activist goals.

While this first chapter has proven a lengthy discussion of historical, subjective, political, and agentic negotiable possibilities between feminism and postmodernism, it provides a feminist-postmodernist framework from which to engage Marlatt, van Herk. and Gunnars. In the cilapters to follow, I use the intersecting frameworks of feminism, postmodernism, and contemporary historiography to examine how each text's feminist-postmodernist engagement with history and female subjectivity incites a reevaluation of the very discursive categories of personal and political, fictive and historical, feminist and 
postmodernist. leaving us to remember how all stortes, including this one, are at once personal, historical, political, and fictional; stortes whose truths are provisional at best. 


\section{Chapter 2: Writing Off Historical Representations of Female Identity in Daphne Marlatt's Ana Historic}

come hack, hesterre calls, to the solsd

groumed of face voul don't wamt io fall

off the' celge' of the world

- Daphne Marlatt, Alfo Hishork

Daphne Marlatt's finu Histuric recounts the life stories of three women through the central narrative frame of the narrator. Annie Torrent. a woman who decides to quit her job as her historian husband's researcher to instead pursue her own personal, political, and academic projects - the writing of a historical novel about a woman. Mrs. Richards, whose name and brief story she comes across in an archive recounting the settlement history of Vancouver, and a coming to terms with her own women-orented sexuality. The narrator expands the meagre historical account of Mrs. Richard's life through an imaginative feminist exploratory reading. one refracted through the context of the narrator's own life story, marked at the tıme of writing by gender and sexuality in particular. In the narrator's novel about Mrs. Richards, whom she renames Ana, she writes Mrs. Richards daring new options which remain cutside the traditional identities allowed a woman in the nineteenth century. At the same time. Annie explores the story of her mother Ina, also an early Vancouver immigrant, whose life comes to a tragic end because of historically and socially repressive Victorian norns. 


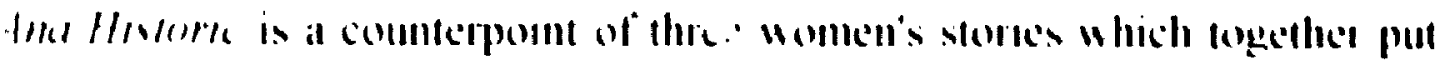
pressure on the cultural constructoms of female subjectivets one the last ano centuries There is the ston of the nameless Mrs. Richands who warrants only a brief mention in the Vancouver archises of 1873, lherebs anciting the narrator to write an inventive fictionalized hustorneal novel about her life, there is the tagke story of the narrator's mother lna, an unhappy and sererely oppressied and repressed woman; and finally, there is the story closest to Marlatt's own. hall of the narrator Annie Torrent's growing up in Vancouver in the 1950, and how she severs the legacy of women as absence through self-naming. flut /mankm worhs to contest historical, literary, linguistic, scientific, and socictal representattons of female identity, discourses which consistently "write-ofl" women Marlatt waltes In alternative representations and subject posituons for women through a postmodemist writung practice of historiographic metafiction and a femmist reading and writing practice of resistance. Through a cross-fertilizatton of such postmodernist strategies as gente deconstruction, intertextuality, self-teflexivity. poststructuralist semiotics, and mese' e'n chlyme', with a feminst revisuonary readung and writing practice which has a reconstructiomst agenda, Marlatl rewrites historical representations of the female subject and politices "the very ferms through which identity is articulated" (Butler, 1990: 148)

Postmodernist aesthetics work to overturn authoritative discousces III Alic! Hostoric: The novelistic genre is one such system of meanng productuon which 
ploss women in limited roles, and is therefore a site of intervention for Marlatt. Anc /lenere is a whiling against the novel. a freeing of the novel's "Lost Girl" (Marlatt, 1988: 12$)^{34}$ from the restrictive plots of death or marriage: historically... the only two alternatives for women protagonists of novels" (Marlatt. 1989: 105). While subversively naming itself a novel on the front cover, Ana H/wfurk quickly undermines any such codification through poststructuralist textual strategies. Marlatt subverts novelistic conventions of plot, linearity, chronology, closure, and narrative continuity through poststructuralist poetics.

Intertextuality works as a disruption device to preclude chronology. linearity, authorial authority, and the centrality of any one narrative in Ancr Histork, where the natrator acknowledges that "a book of interruptions is not a novel...this is not a roman / ce, it doesn't deal with heroes" $(37.67)$. The intertext and the palimpsest are two structures of intertextuality used by Marlatt to disrupt any central narrative or authorial voice. ${ }^{-2}$. Ano Hisforic contains a network of authoritative intertexts, where fragments from historical, scientific, and journalistic reference texts, listed at text's end under "Acknowledgements" - sources such as Gilene lans of legggeng, Woodsmen of the Wess, Larly lancouver, and the

" All subsequent references to Ana Hsstoric will appear in parentheses by page number only.

An Ink'rtext is "an insertion that exposes its text and that leaves no doubt of its origin and its source": a palımpsest is an intertextuality which leaves only a trace of its origin behind through a revision of the source text in the host text; a rhzome', conversely, which we will see in Chapter 5 with Gunnars' The Prowler. is an intertextuality which "exposes the absence of any source" (de Toro, 1994: 421). 


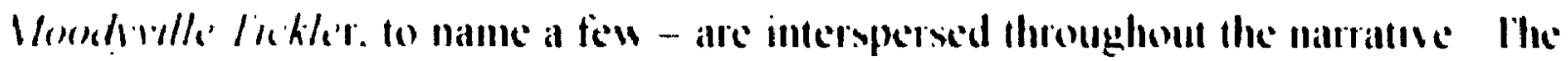
authoritative and official natue of these mtertents work to interrupt and conttast the narrator's ahistoric. pessonal, and imaginatese whting with their definteve lone Marlatt's narrative is primarily marked by a palimpsestec intertevfuality. however, whereby one history is overwritten with another in a doubly coded collage. and where the past is recontextualized in a new context (de Foro, 1994. 427) Innie's version of Mrs Richards' life story is mounted over official history's version and. as the narrative proceeds. effects a literal seemrang of history as the personal narative displaces the official historical one.

Furthermore, the mirroring structure of mese e'l chlme'. which translates literally to mean "putting into the abyss," is a postmodern tevtual strategy for incurring metafictionality by enabling a narrative to take itself as its theme (Dällenbach, 1989: 35). ${ }^{77}$ Marlatt's use of musc 'n ahıme' establishes a confusion of narrative levels, where there is a novel withm a novel. Anmie, the narrator of Marlatt's "novel" Ana Hostoric, is writing a novel about Mrs. Rachards. There is a dizzying layer of intersecting narratorial voices and names - Ammic, Ana, and Ina and a layering of other writings: Ana's journal, Annie's unofficial writings of her own, Ina's "scribblings," imagined conversatior, between Annie and lna, and various historical, scientific, and journalistic material which appears in italics and quotations. Half way through the novel, Annic asks: "Ana/lna whose story is $\because \quad$ Dällenbach defines mise en ahyme as "any aspect enclosed within a work that shows a similarity with the work that crntains it" (1989:8). 
Ilus")" (6,7) What is mole. the narrative pont of vew refuses an! norelistic stability and shifts between 'i' and 'you' "you who is you or me she a part struck off fiom me apart separated" (11). The 'you' altermates to signal Ina. Ana. Anme, in addition to "anywoman's you" (Marlatt. 1989a: 100$)^{. *}$ Marlatt's use of a lower case ' $i$ ' for Amnie Torrent's writing is significant. finally. for it de-authorizes the authority of the authonal voice:

when we write I we discover that the singular column with its pedestal and cap. this authorized capital letter, far from being monolithically singular is fill of holes a wind blows through. whispernng contradictory umages. echoing others' words (Marlatt, 196)(192)

The novelistic genre is further undermined in fra Hworrc through the text's inconclusive conclusion The narrative "ends" with a poem that invokes the reader to figure herself not only in its reading, but in writung the rest of the story: "your desire, reading us into the pages ahead" (postscript). Through this metaphor of the perpetually turning page. Marlatt denies the novelistic convention of narratuve closure, and rearranges traditional author and reader roles by subvertmg authorial authority and intensifying reader participation.

In addition to undermining literaty constructions of female subjectivity through such poststructuralist textual strategies as mos' c'n uhimme' intertextuality. and shuftung namation. flus Hostoric combines metafictionality and metahistoricity in a postmodern writing code of historiographic metafiction, to undermine " Mar'att describes the narrative 'you' as the "you $i$ also am": "(not a third person, as in totally other, and not quite the same as me). 'You' is a conduit, a light beam to larger possibility, so large it fringes on the other without setting her apart from me" (1990: 188) 
historical as well as ficthonal representatens of women. and to trouble the

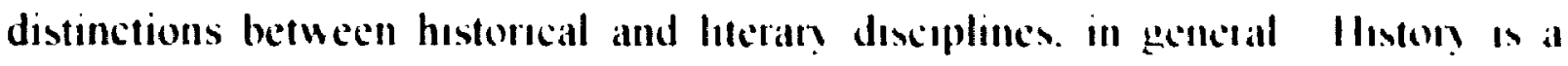
second authontatise discouse, then. Whech delimms women's identit! and experiences, and therefore figutes predommantly in tho //saors.

Historiographe metaficton works to illustrate the producteon of meammg in both history and fiction writmg. It is a popular postmodern wittmg stlallegy that recalls the historical while complicating the relationshep between history and fiction, and thereby the relationship between truth, lie, memon, and invention B, paralleling the epistemologkally and ontologically provisional nature of listory and its arsenal of "facts" with that of ficton ("that's the Houble wilh histon it

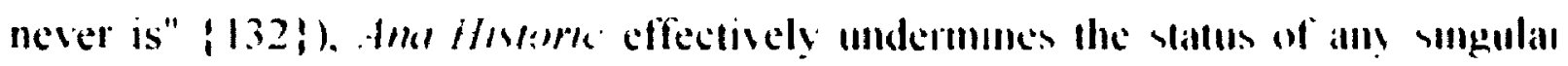
histosical representaton of women, from the numelecull century Viclorian (sub)version of Mrs. Richards to the 1950s version of lna Whell the narrator Anme deliberates over the fallacious balance of powe betucen historical ard fictive discourses an imbalance which sets them in opposition "but once history's on stage, histrionic as usual (all those was, all those historic fudgements). the a-histonc hasn't a speaking pant what's Imagmation nest to the werght of the (f)actual?" - 7oe replies by tipping the scales in the decclion of unagination "you've imagened your way into what she really wants" (139-40, my ltalics) Annie finds that the oppositon between hostoy and magnation regunes reconceptualization bevond binarial oppositson "but what if they balance cach 
other and we live in history and imagination. out and in. out and in" (139.125). Marlatt proposes a countergenealogy for the lost women of history, one which incorporates history and fiction, imagination and invention, as strategies of re-embodiment: "[Mrs. Richards'] real story begins where nothing is conveyed. where she cannot explain, describe -" (83).

Ana Hestoric situates itself between history and fiction, and in so doing effects a blurring of the distinctions between the two discourses. Through an engagement of postmodern historiography and its literary counterpart, historiographic metafiction, Ano Hostorrc takes up the rhetoricity of history and effects a feminist-postmodernist critique of both history and epistemology. History. like the language in which it is recorded, is shown to be a highly contextual version of the past; a version that is in need of some revising from the direction of those who have been powerless to tell thrir stories, among those of which are women. The arbitrariness of just what makes history is evoked by Marlatts juxtaposition of the superfluously detailed historical record of a boat race with the unrecorded but momentous birthing experience of Jeannie Alexander (113-27). The minute details of the boat race emphasize how history is obsessed with the imbalance of power; that is, with the fastest, the best, the winner:

'Sime sall the' 'Anme liraser' is the heller hoat. Others, again, will kell yem that the 'Pearl' is the hest heat. But that the 'Anmie liraser' had the herter crell: Siome go further and sav that the 'l'earl' is the boat and had the hest crew: hul that luck or the curre'n' was agannst them...' (122). 
In contrast to this historical "rattling of paper news" where worth is detcrmined by competition, is Jeannic's birthing experience

Head back on the pillow, knees up. she was breathing hard. concentrating all of her being on the upheaval within ...an elemental creature. sweal beading her face. hair pushed back by Susan's patient hand. moth open and panting with pain... woman a rhythm in touch with her body its tides coming in mol first mor las nor lost she circles back on herself repeats her breathing out and in two heartbeats here mol w/mmmg or lessmg labouring into the manifest (122,124-5, my italics).

Marlatt's juxtaposition of the "historical" boat race alongside the "unhistorical" birth immediately de-authorizes history, and makes room for the personal

And Hosfork continually crosses, and thematizes its crossings, between history and fiction: "the trouble with you. Annie," notes the narrator's mother, "is that you want to tell a story, no matter how much history you keep throwing at me" (27). The result is a democratization of historical and literary discourses. where the narrator is both novelist and historian, searching the Vancouver anchives for information regarding a nineteenth century woman named Mrs Richards Thus the word play in the text's title on "ahistoric" (In/(a //s/orre), signilies lhat which is outside of the boundaries of history, like the real and imagined stories of Mrs. Richards and other women.

Where "remembering is a fiction" and the differences between fictional and factual acts are collapsed and signified as "(f)acts," the boundaries between history, fiction, and life writing are blurred in Ano Hestork (Marlatt, 1989 $9(1)$ Situated at the interstices of history, fiction, and autobrography (or life writing), 
Marlatt's project works in the junctures of memory, imagination, invention, official recorded history, and lived experience. Marlatt demonstrates the collusion between the real and imaginary with Ana's journal:

that journal of hers that later, years later would be stored in the dustfree atmosphere of city archives. she was writing what would become a record, but then, then her hand hovered, her mind jumped. she could have imagined anything and written it down as real forever (29-30).

History is an act of memory and the imagination in Ana Hiski, Ic, where what makes history is highly subjective and selective. "what is a 'world event"? getting a piano was a world event in that 'obscure settlement' because years later somebody still remembered it...these are not facts but skeletal bones of a suppressed body the story is" (29). Marlatt's revisionist historical project entails a reading between the lines of official history, where much is revealed in the gaps and silences: "holes, there were holes in the story you had inherited. holes in the image" (26). Annie's historian husband serves as the authoritative voice of tradition in his claim that "history is built on a groundwork of fact" (134). Annie abandons her husband's search for the missing facts of history to instead search for the missing persons of history (134). Annie notes the discrepancy between fact and event. how facts ate already interpreted, discursive events: "what is fact? act the $f$ stop of act. a still photo in the ongoing cinerama" (31) ${ }^{20}$ On a

2" Hutcheon makes a useful distinction between event and fact: event is the raw uncontaminated material, which exists but in already mediated ways, while fact is that which we construct from an event, the event given meaning (1989a: 57). 
metaphorical level. Annie's rejection of her job as assistant histoman significs a rejection of history itself.

The epistemological perspectivism which results from historiographic metafiction is not nihilistic or solipsistic. however. fHa H/v/(orn deconstructs mol the material reality of events that may or may not have occurred, but that authoritative and sweeping discourse which pretends to historiciac women even as it ahistoricizes them. It is "the historic voice (voice-over), elegiac. epithetic. a diminishing glance as the lid is closed firmly and finally shut. that was her. summed up. Ana historic" that Marlatt undermines through an engagement with postmodern historiography (48). In keeping with a postmodern historiographic aesthetics of epistemological, ontological, and historical doubt, Marlatt underscores the rhetoricity of history, the arbitrariness of any historical account the rattling of paper news his mental ticker-tape of what is worthy of attention (or divisionary, small artificial columns of another world). .all these diversionary, turn the traffic of the mind around a gaping hole, this entry into or exit from - (blank, blank) - (122-3).

Ane Hesterce is about moving beyond history to include the ahistorical, the personal, since "[h]istory becomes an irrelevant concept to someone who has no history, who is outside of it" (Marlatt, 1989: 102). Among lhose rendered ahistoric are women: "there are histories of properties changing hands and names, of civic developments named for those who pushed them through. amidst all this there are brief references to women" (47). I,ike van Herk, who outlines the male 
settlement history of the west, Marlatt illustrates how history is a record of the powerful by the powerful:

the ships men ride into the pages of history. the winning names. the nameless women wino are vessels of their destiny. the ship R.H., H.O. ride into history as stars on board the mute matter of being wife and mother ahistoric, muddled in the mundane (121).

Annie's "scribblings" are a literal underwriting of history: "but now half-hidden under pages of notes, urder quotations from archival material, under sheets of xeroxed photographs (the facts), there is a scribbler on her table" (78). Marlatt's project in Ana Historic is a feminist-postmodemist revisionist historical one, in which she works to problematize historical knowledge while at the same time stressing the importance of an alternative feminist history which "step[s] inside the picture and open[s] it up":

framed by a phrase that judges (virgin / tramp), sized-up in a glance, objectified. that's what history offers, that's its allure, its pretence. 'history says of her ...' but when you're so framed. caught in the act, the (f) stop of act, fact - what recourse? step inside the picture and open it up" (56).

Language, the very material out of which authoritative historical and literary discourses are made, is a third area for intervention in Ana Historic. I.anguage is a discourse in which women have to struggle to account for themselves: "words, that shifting territory. never one's own. full of deadfalls and hidden claims to a reality others have made" (32). The problem Marlatt is faced with in Ana Historic is how to escape linguistic colonization: "and what if our heads are full of other people's words?" (81); "if they could speak an 
unconditioned language what would they say?" (75). Marlatt illustrates how women are as absent from language as they are from history, where "Ana. struggling to account for herself...'conveys nothing. nothing of these sawdust byways..." (83), and Ina scribbles "in a language which was not |hers]" (1.3.3). The problem with Ina's writing - "family stories for The Re'uder's l lege'st" - is that she does not write for herself; hers are "stories that lost their humour in description, faded away in proper sentences" (20). Marlatt finds language to be the fundamental level from which to begin deconstructing female subjectivity: "When we change language, we change the building blocks by which we construct our reality or even our past 'reality.' history" (1993: 188).

Language is a significant place for transformation in Ama Hosturk, where Marlatt practices linguistic and semiotic deconstruction through etymological work on a variety of words in order to illustrate how "words, that shifting territory (are) never one's own" and "full of deadfalls and hidden claims to reality others have made" (32). The following four examples illustrate Marlati's metalingual work in the text: Iruc - "exactly conforming to a rule, standard, or pattern; trying to sing true. by whose standard or rule? and what do you do when the true you feel inside sounds different from the standard? (18); wmhoy - "tom, the malc of the species plus boy. double masculine, as if girl were completely erased. a girl, especially a young girl, who behaves like a spirited boy - as if only boys could be spirited" (13); lady - "a word that has claimed so much from women trying to 
maintain it...kneader of bread, mistress of a household, lady of the manor, woman of good family, woman of refinement and gentle manners, a woman whose conduct conforms to a certain standard of propriety" (32); and vagına - "a word for sheath, the cover of a sword" (62-3). As Goldman points out, Ana Historic is about denaturalizing standard English "to illustrate the way in which the language reflects the concerns of imperialism and inscribes 'reality' as constructed by the British Empire" (1993: 18). The narrator Annie does just this as she recounts her mother Ina's preference for the more dignified "proper English" of Britain: "Canadians dun't know how to speak proper English" (17). Annie tries to sever the linguistic legacy of her mother, which continues to frame her world in a Victorian "English gentility" context:

impasse: 'my very words' were yours. woolies and sweeties, hotties and hermits...two languages. two allegiances. impasse: impossible to exit. dead end. when the walls close down. the public/private wall. defined the world you lived inside, the world you brought with you, transposed, onto a Salish mountainside. and never questioned its terms. 'lady.' never questioned its values. English gentility in a rain forest? (23-4).

Marlatt describes this etymological work as a moving "out through the words" as "a way out of the blank that faced her" (45).

Ana Historic engages language metalinguistically as both a poststructuralist and feminist deconstructionist strategy. Marlatt dissects the language "of definition and documentation on which the groundwork of history is built," proposing in its place the "scribbling" by Annie, a writing in "the language of an 
interior history" (Tostevin. 1989: 37). Combined with this etymological work is Marlatt's radical punctuation, grammar and syntas, and a use of blank space and parentheses, all of which function "to get out from under the sentence" (Cooley. 1989: 70).

Like van Herk in Places fiar lirom l:llesmere, Marlatt is particularly concerned with history as a process of naming, a linguistic process from which women have been excluded:

history is the real story the city fathers tell of the only important events in the world. a tale of their exploits hacked out against a silent backdrop of trees... so many claims to fame. so many ordinary men turned into heroes (where are the city mothers?) the city fathers busy building a town out of so many shacks labelled the Western Terminus of the Transcontinental, Gateway to the East - all these capital letters to convince themselves of its, of their, significance (28).

Marlatt shows official history to be an act of colonization through naming: "history the story ... of dominance. mastery, the bold line of it" (25). As in I'laces Far from Ellesmere, there is a connection between the colonization of western Canada with the naming of women in Ana Historic: Marlatt "makes connections between the phallocentric excising of women's history and the colonization of British Columbia" (Grisé, 1993: 93). Women like Ana are overwritten with the names of men - "entered as Mrs., she enters his house as his wife. she has no first name, she has no place, no place on the street, not if she's a 'good woman.' her writing stops" - just as the land bares the name of men who have conquered it: "'Douglas fir...named afier I avid Denglas, a well-known holamust"' $(134,13)$. 
Science, like linguistic. historical, and literary productions, is another discourse which seeks to diagnose/remove women, and therefore a fourth site for intervention in Ana //ss/oric. Science is likened to history in particular, as the narrator draws a comparison between "hystery" and "hysterectomy": "hystery. the excision of women (who do not act but are acted upon). hysterectomy, the excısion of wombs and ovaries by repression, by mechanical compression, by ice, by the knife" (88) The narrator's mother Ina is diagnosed with hysteria and given electric shock treatment until she is literally effaced:

mum. wandering around in some lost place, incapable of saying what it was they'd done to you. under the role or robe was no one. certainly mother was gone...they erased whole parts of you, shocked them out, overloaded circuits so you couldn't bear to remember. re-member (148-9).

While Marlatt uses the structure of historiographic metafiction to deconstruct the authority of historical constructions of female subjectivity, it is primarily through the use of postmodern irony that Marlatt disempowers the authority of scientific discourses in their construction of women. Irony is "a powerful subversive tool in the re-thinking and re-addressing of history.... a rhetorical strategy for working within existing discourses and contesting them at the same time" (Hutcheon, 1989b: 154). Irony works well in Ana Historic, where we find extracts from such authoritative historical texts as The Hestory of Shock Treatment and The Myth of Analysis on the nature of women's bodies, electric shock treatment, and hysteria (89.144-5). Take the following passage, for example, a brief explanation of the procedures of shock therapy: 


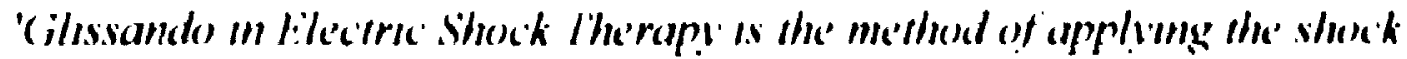

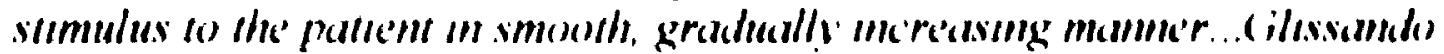
rate of rise, variahle from t secomds to 2.0 secomds in steps of 10.2 secomds

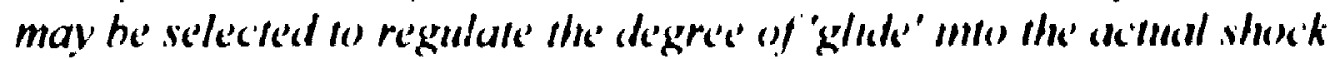
treatment... In the ammesta coused hy all slectrac shocks, the livel of the whole intellect is lowered ...' (144-5).

The objective. rational tone of the historical and scientific documentary voice works in contrast with the shocking and brutal significance of the words, to deconstruct any authority these scientific and psychological discourses on women might have once had.

In addition to a rejection of historical, literary, scientific, and linguistic discursive constructions of women is Ana Historic's deconstruction of two centuries of social scripts for female identity. The central plot for women in both Ana and Ina's generations is that of wife: "trained to exhibit a 'good mind,' but only 'within reason' - reason being utilitarian, education as part of 'attracliveness' leading to marriage" (17). Like Mrs. Richards before her, Annie is written off by that "world of middle-class romance" plot for women she inherited from her mother: a "path that led to marriage or death, no other fork in the trail" (99).

Marlatt's task in Ana Historic is to escape the prescriptive choices for women passed on through a legacy of patriarchal repression: "o the cultural labyrinth of our inheritance, mother to daughter to mother..." (24). One of the histories that Ana Historic revises is that of repressed female sexuality, a matriarchal legacy. the mothers, the inheritance of the mothers. you taught me a lot. you taught me the uneasy hole in myself and how to cover it up -- cover girl, the 
great cover-story women inherit in fashion and makeup. you taught me how I was supposed to look, the feminine act (60-61).

Marlatt's narrator Annie breaks the social and historical legacy of mothers by affirming her own desire for another woman, and in so doing. offers Ana the same lesbian alternative that has been consistently written off. Marlatt has Annie further effect an erasure of the female plot through the agentic power of naming: Annie renames Mrs. Richards Ana, just as the narrator renames both herself and Ana Annic Torr'nt - "Annie Richards. the sound of a door closing...Annie isn't Richard's or even Springer's...Annie Torrent, i said" (152) - in order to disrupt the plot of marriage and sexual repression she inherited from her mother, 'torrent' being a sign for the coming forth of voice and desire: "what does a woman do with her unexpressed preferences, her own desires? (damned up, a torrent, to let loose" (35).

Ama Hsioric contests historical, scientific, literary, and linguistic representations of female subjectivity through a politics of location (Borsa, 1990) and "situated knowledge" (Haraway, 1991). The problem with history is it is writing ahom "you who literally cannot speak. though they speak about you" (105). Contextual responsibility, whereby the narrator, historian, author, and theorist takes her own location into account, is demonstrated when the meagrely documented history of Mrs. Richards becomes entwined with that of the narrator's (Anme Torrent), the narrator's mother (Ina), and with that of Marlatt herself: 
"Ana Ina whose story is tinis"" (67). It is Loe who reminds. Annic, in quest of what to do next with her characters, that her characters are an extension of herself: "'characters.' you talk as if they were strangers. who are the'y uf the'l aren't lour?" (140, my italics). Almo Hostork enacts the confluential relationshop of subject and object, author and subject. vision and version, with Annie's mirroring of her own desire for Zoe in that of Ana's for Birdie: "Annie's decision to write Ana Richards into the provisional role of Birdie/Bridie Stewarts lover acts as a rehearsal on paper for her own decision to 'take the leap' into a women-identified relationship with Zoe" (Kelly, 1995: 85). As well, Marlatt's revision of the female subject in Ana Historic effects a politics of location through an autobiogtaphical writing practice." The autobiographical element in Aha Hosforrc is fundamental in reinforcing the interaction between vision and version. Just as Marlatt writes her own (historical, geographical, sexual, professional, and perhaps other) idemlities into her narrator Anne, so does Annie write herself into Ana. Ano //n/mric moves between a postmodern philosophy of doubt and a feminist agenda of politicl/ation of the subject through epistemological perspectivism.

i1) That Ana Historic is autobiographical is clea in Annic's resemblance to Marlatt, who also grew up on the North Shore of Vancouver, and who is also a lesbian. In an interview with George Bowering. Marlatt comments on the interaction between history, fiction, and autobiography in Anc I/s/oric "funny thing when we say remembering is real, and inventing is not - inventing is purely imaginary or fictional. What interests me is where those two cross. I think one can still be autobiographical and in fact be quite imaginative. In some cases I don't even know where the seam between those two worlds is" (1989: 96). 
That Marlatt's project is both feminist and postmodernist is evident in its dual agenda. Ana Hisforic moves in a continuum between a postmodernist deconstructionist agenda, where as we have seen. Marlatt works to undermine linguistic, historical, literary, scientific, and social discourses about women, and a reconstructionist agenda, in keeping with material feminist goals to re-embody the female subject in new versions of history: "it's up to me to pull you through. this crumbling apart of words" (11). And Marlatt engages in just such a "pulling through": Ana Historic figures women engaging in history-making through alternative reading, writing. and naming practices. Since Annie's characters "wanted something to do not something that might be done to them." we find a number of ahistorical writings in Amo Historic which challenge and decenter the official histories: Marlatt's revisionist historical account of a nineteenth century woman: Mrs. Richards version of history written in her journal; Annie's revisionist historical novel about Mrs. Richards; and even Ina's scribblings which she hides under the bed (12-13). But perhaps the most overt acts of naming are Annie's renaming of herself and Mrs. Richards.

fluc Historic is about getting out of official history - "the 'right track'...full of holes, pot-holes of absence" - and about imagining new options for women, altemative histories and plots: " $i$ wasn't dreaming of history, the already-made, but of making fresh tracks my own way" (98). In light of the possible "fact" that "history martied her to Ben Springer and wrote her off," Annie rewrites Mrs. 
Ricl. rds' histong in order to give her some new optons, begmmng with a fiust name "what is her first name" she must have one -.. so far she has only the name of a dead man. someone somewhere else" (1:3, 37) Anne's chonce of Ina is significant in that it is a name which deties any smgular, lmear reading. as a prefix "ana" carries the multiple senses of "back. again, thoroughly. up." (licgge, 1983. 40). Annie revises the history of ivlrs. Richards by magining "all the other selves she might be" outside the narrow confines of wife widow or school teacher, options like writer, pianist, explorer, pioneer, companion to Birdie Steward (140) Annie writes Mrs. Richards cte particularly daring ident1ly - that of lesblian - by reading imaginatively and inventiveiy between the evasive lines of history you turned intrigued, and your body turnmg in its long skint, its filted waist that hugs your hips, is caught in the act, you have caught yourself turning in Birdie's eyes. turning because of a cpark, a gleam, your eyes are green (you had forgotten that) and you know them lit with th. look of something you almost meet in Birdie's brown. you had not imagined - this as history. unwritten (109).

Feminist revisionist criticism is equally present in Marlatt's project, then, and works as an agency bui ${ }^{2}$ din $_{b}$ strategy for countering traditional inscriptions of female subjectivity, and describes in part the project undertaken by Marlatt in Almet Histeric, a project mirrored in her narrator's historical novel about Mrs. Richards Marlatt's is an emancipatory reading and writing strategy in which the narrator writes new options for Ana and herself:

She wanted to be free oi at least freer than she was, than she had managed to be. She wanted to know what it would be like to rent rooms in the Granville Hotel or the Deighton, buy a piano (passing ships had them 
sometimes), give music lessons and forget about answering to school trustees (104)

Women writing in Amo Hiscuric write thimselves into being. Marlatt's revisionist projest is a question of re-embodying the female subject. "remembering. not disbut re-meml.erıng. putting things back together again. the things that have been split off, set aside" (51) Writing is thus an embodiment of the self in language: "the unspoken urge of a body insisting itself in the words" (46). Take Ana's writing.

she is writing her desire to be, in the present tense, retrieved from silence. each moming she begins with all their names. she has taught them to say. 'Present, Mrs. Richards.' and so, each morning st.e begins with her name. a name that is not really hers. each evening she enters her being, nameless. in the book she is 1 .riting against her absence (47).

Ana Historkc advances a "writung against her absence" that is both feminist and postmodernist in its subversion of prescriptive social, historical. literan, and scientific discourses (47). Marlatt's project in Ana Historic is on one hand to clear space in language for women's presence. Marlatt's text is about finding another kind of writing: "not a tool, not a pure instrument for getting a grip on the world.' 'it contdins menaces.' traps. pitfalls" (133). Marlatt combines the postmodctn strategy of deconstruction and doubt with a distinctly feminist revisionisi reading and writing strategy of collaboration and solidarity: "she was looking for the company of another who was also reading" (45). The narrative voice 'you' rather than 'we' is significant. for it recognizes difference and 
incorporates reader and writer into a collaborative literan pratıce (Marlatt. 1990) 193). Imagination and invention are integral for a femmist reading process, if Annie were to simply fill in Mirs. Richard's probable ston. It would foreclose the

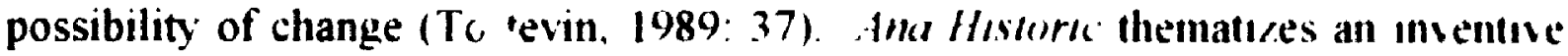
reading process at once historical and imagnary: "if im telling a story im untelling it. untelling the real tying to get back to the child who went too far, got lost in the woods. walked into the arms of Frankenstem" $(1+1)^{\text {" Marlatt's }}$ proposed feminist literary practice entails an cmbode'd reading of "she my I ost Girl. my Heroine" (12); a hıstoricizıng of women despite history's continual passing-by of women by "with a nod between the lines" (1.32) The birth episode in Ana Histork works as a metaphor for a new relationshup of women to language and history: the newborn "a massive syllable of slippery flesh" (126) Marlatt's is a writing. finally. "cut loose from history and its relentless progress lowards some end. this is undefined territory, unaccountable. and so on edge" (81)

i) The monster metaphor figures extensively in Amo Howrorc and carrics several significances. On one hand. the monster represents fear of difference "a man's name for man's fear of the wild, the uncontrolled that's where she lives (142). The monster also signifies the misrepresentation of women and the legacy of oppression :-omen inherit: "there is a monster, there is something monstrous here...how reaceful $i$ thought. how $i$ longed for it. a woman's place. safe suspended cut of the swift race of the world. the monstrous lie of it the lure of absence. self-effacing" (24). As Goldman points out, the monster serves also as a trope "for the feared and desired lesbian possibility" (1993. 19) Finally, 'monstrous' signals the multiple possibilities for female subjectivity which res:ilt from altemative, imaginary/historical revisions, as in a "monstlous leap of imagination" (135). 
Marlatt proposes a revisionist history by, for. and about women; a writing practice that re-embodies the female subject in a revised language and history through imaginative rememberings. Mrs. Richards' "personal" writing is excluded from history: "they think her journal suspect at the archives. 'inauthentic,' fictional possibly, contrived later by a daughter who imagined (how ahistoric) her way into the unspoken world of her mother's girlhood" (30-31). Yet by setting the authoritative historical quotations against personal narratives Marlatt underscores "the disjunction between History and personal history" (Waring. 1992: 252). Marlatt uses such female bodily experiences as birth, menstruation, and lesbian desire as tropes for this alternative project of writing women's presence against the absence of history: "the real history of women, Zoe says, is unwritten because it runs through our bodies: we give birth to each other...it's women imagining all that wc..en could be that brings us into the world" (131). The torrential and cyclical nature of menstruation. "the period that arrives at no full stop." is the "interior" or personal history that Marlatt seeks:

not the language of definition, of epoch and document, language explaining and justifying, but the words that flow out from within, running too quick to catch sometimes, at other times just an agonizing slow trickle, the words of an interior history doesn't include ... (90).

Ammie's writing is set in contrast to the traditional historical and fictional writing of Annie's husband and mother. Ina's and Richard's imagined responses to Annie's writing. moreover. serve as the voices of the androcentric tradition, judging 
Annie's writing from the perspective of authority and rejecting her untraditional writing practices:

- now Annie. now youre indulging in outright speculation. this isn't hostory. it's pure invention.

- but what about the personal history of Mrs. Richards? (so personal it is hidden.) with what irony can we imagine her writing Mrs.?

- you're simply making things up. out of a perverse desire lo obscure the truth.

- whose truth, Ina? (55-6)

Richard's response is much the same: "but what are you donng? i can imagine Richard sayiag...this doesn't go anywhere, you're just circling around the same idea - and all these bits and pieces thrown in - that's not how to use cuotations" (81).

Ana Hestork is a writing of the "subject in process," a writung against absence and "positivistic assumptions of a universal male subject" (Kelly, 1995. 76). Just as Places lar lirom l:llesmere frees Anna from Tolstoy's entextment, so does Ana Historic work to free Mrs. Richards from her meagre archival existence: "break the parentheses and let it all surface! falling apart. we are, i am. we have fallen apart. the parts don't fit. not well. never whole never did" (150). That Mrs. Richards is mentioned only in passing in the Vancouver archives incules the narrator Annie to engage in a feminist revisionist project which involves searchıng out the missing women of Vancouver's settlement history and their personal (as opposed to official) histories Mrs. Richards' brief appearance in the Vancouver archives is exemplary of women's absence in history: 
No one knows when she came or how long she had been there when she was appointed schoo! teacher. Or even whose widow she was. She arrives in the records in the fall of $1873 \ldots$ and fades into the northern shoreline of Burrard Inlet as Mrs. Springer of Moodyville, of whom we hear nuthing more (Marlatt, 1988: 39).

Mr:i. Richards' life is further obscured "in the gap between two versions": contradictory historical accounts figure her as either a Hastings Mill school teacher who lived in a cottage behind the schoolhouse, later marrying Ben Springer (48), or as a school teachel who rented rooms in Gastown and gave piano lessons (48,106). As Waring notes. "[t the choice... is between two different narratives. The first is the story of marriage...[t]he second is the story of an independent woman" (1992: 254). Marlatt's and the narrator's dissatisfaction with the lack of information with which official history attempts to explain Mrs. Richards' life, the "facts" as it were, leads them to seek another version of history: "in that brief statement there is nothing of the friendship that existed between these women a generation older...nothing of the unspoken sharing of their lives. something is lacking" (48).

Marlatt's project clearly combines a postmodernist deconstruction of the stable and unified subject with an affirmation of alternative forms of subjectivity for the female subject, thereby moving in a continuum between de- and re-construction. Whether Marlatt's project is essentialist in its replacement of a paternal genealogy of women with a gender-based lesbian one, remains a point of contention among critics." However, it seems to me that Ana Historic is : Tostevin argues that "[w]hile lesbian-matemal texts are crucial in 
precisely about mot inscribing a singular female subject, as suggested by the text's very tripartite narrative structure, metafictionality. and perspectivtst philosophy." As metafiction. Marlatt's text is highly aware of its textuality, its constructedness. this works to espouse an epistemological perspectlvism whereby any "truth." including Marlatt's story in Ana Historic, is temporary and contexfual. Moreover. the multiple narratives occurring simultaneously, those of Annie. Ana, and Ina, resonate back to Haraway's image of the multi-perspectival subject (190)| 192). and work to subvert the centrality of any one story for women or the centrality of any singular novelistic hero. Marlatt does not fix the subject position for women as lesbian. Rather, she posits lesbian identity as on' possibility of female exploring the unrepresented, the unthought, it is important that they not be prescriptive in their attempt to describe women's writing and lives"; thus "the female subject writing herself on to 'the blank' page of history" need encompass "a multiplicity of differences that cut across sexuality, gender, form. class, race" (1989: 38).

; $\quad$ Brand, Grisé and Goldman concur that Marlatt's feminist revisionist project is neither essentialist nor prescriptive in its treatment of female identity. Brand argues that "Marlatt's self-consciousness and acute awareness of contradiction and ambivalence in the writing act, implies a complex notion of community and difference which stands as a model in re-visionary imagining, in the feminine" (1989: 40). Grise's anti-essentialist reading of Marlatt is founded on Marlatt's narrator's treatment of the native Siwash women in her novel. "Harrict and the Siwash woman who appears earlier in the text act to 'step inside the picture and open it up,' forming an internal critique of Annie's project" (1993. 95). (jrisé thus concludes that "[t]he revisionist project in Ana H/storrc involves not only deconstructing the official version of history, but also critiquing the potential for monologism in this feminist revision of history... The colonizer's projection of the Other cannot be sustained within a feminist critique of history; this projection is thus revisioned in Ana Historic through the present absences of these indigenous women (1993: 95). Similarly, Goldman reads Ana Hes/oric as a project which details a lost genealogy for women, thereby based on a "nominal essence" only (1993: 119). 
subjectivity, a particularly effective one in the narrator's case for countering the V.ctorian legacy of sexual repression that Annie seeks to escape in her own and Mrs. Richards' lives, and in the author's case, since it is one of the contexts out of which Marlatt herself writes.

While Marlatt does offer a women-identified position for both her narrator and Ana Richards, she deliberately leaves the sign of female identity open. Marlatt escapes essentialism in Ana Hıs/orrc by not prescribing any one definitive story for Ana: "she is free to look out at the world with her own eyes, free to create her vision of it. this is not history" (30). Again Marlatt's choice of 'Ana' is significant: "that's her name: back, backward, reversed again, anew" (43). Furthermore. Ana Hestorkc resists any definitive ending; in a section entitled "Not a Bad End," we are left with Ana reading another woman's story/desire: "Lifting here eyes in a sudden rush of desire she reads likewise in Birdie's face, a sudden rush of relief - 'You see it is written across my face,' she admits" (139). This is the last we know of Ana, the rest of her story left open: "Ana, what are you doing? under the guise of such formality, you've moved beyond what $i$ can tell of you. you've taken the leap into this new possibility and i can't imagine what you would say" (139). Thus even the lesbian identity which Annie affirms at text's end remains one option among others, and is contrasted by the identity of Jeannie's maid, the Siwash woman Harriet, for example, who is multiply marked/erased by colonization, race, class, and gender. The final episode, which figures Annie and 
Zoe consummating their mutual desire, is not the end either in a postscript that follows, there is a poem that invokes the reader to continue the story through the metaphor "of the continual turning of the page" (Marlatt, 1993 188). Marlatt subverts closure, and thereby the very structures of history and the novel, by refusing to "end" Ana's or her own story. The narrator realizes that stories, like that of her mother's, continue to unfold in new retellings: "i'm left here telling. untelling, unravelling all the stories, faltering to a stop ... how should this one end"! and is there one? $(137-8)$.

Ana Historic is, then. a politically and ethically engaged feminist project which "suggests... a way out of the old colonial story" (Brand, 1989) 40). Marlatt's project in Ana Hastoric combines postmodern aesthetics of doubt to "untell" literary, historical, linguistic, scientific, and social stories about women with feminist criticism, to open up the possibilities for alternative, inventive, and imaginative histories and subjectivities. Situated at the interstices of fiction. theory, history, and autobiography, Ano Histuric deconstructs the false alternatıves of history and fiction, truth and imagination, personal and official history, through a combination of historiographic metafiction and feminist criticism. Marlatt's strategy of resistance in Ana Hirtoric is a praxis which combines feminist theory with postmodern metalingual, metahistorical, and metafictional textual strategies, in order to engage revisionary rereadings and rewritings of the marginalized female subject in and out of "official" history. 
Through a feminist-postmodernist strategy of intervention into historical, psychological, scientific, linguistic, and literary productions of women, Ana Hesforic radically questions the authority of male texts, and offers new genealogies through a philosophy of epistemological perspectivism and a politics of location. Anc //ss/urk writes off the historical, fictional, scientific, and social plots of Victorian sensibility, death, marriage, and madness, which consistently seek to diagnose women as wife, mother, widow, prostitute, handmaiden or, if all else fails, mad, and writes in new possibiluties for women like writer, feminist revisionary historian, autobiographer, and lesbian; options that: "fly in the face of common sense, social convention, ethics - the weight of history. to fly ..." (146). 


\section{Chapter 3: Getting Out of Line in Aritha van Herk's Places Far From Ellesmere: Viscera, Vantage, and the Politics of Geografictione}

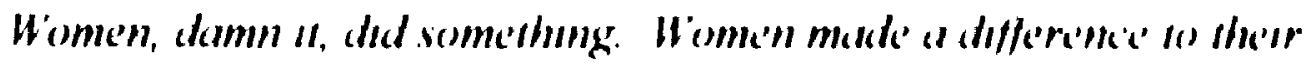

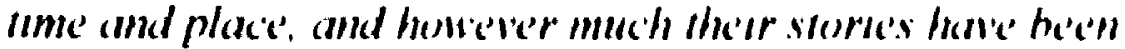
fragmented or censored. the't demand a rededeng... c'very womem's

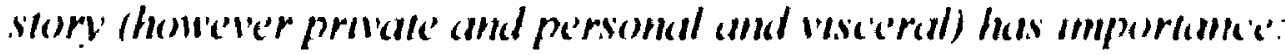
fior ats anger, for as fierce' and unrele'nteng rebelleon, for an umu'dlinghess to cat shit, to he mam-hamdled, pushed around. - Aritha van Herk, "In Visible Ink"

Aritha van Herk's Places liar lirum l:llesmere is an experiment in trans-genre writing; combination literary essay, travel journal, and autobography, the narrative moves from three autobiographical chapters recounting the narrator's life in the prairies, to a final chapter which marks a trip she takes up north to Ellesmere Island. On this trip, the narrator takes along Tolstoy's .Immo Kor'mm, and combines the exploration of the island geography with her femmist exploratory reading of Tolstoy's text.

Just as Ana Historic is about writing off historical representations of female subjectivity, so is Places lar lrom l.llesmere about "getting out of line" getting out of the "great black steel lines of fiction" (Wiebe in van Her, 1984a: 17) that signify the obdurate trajectory of the male narrative, and getting out of male historiography "[s]coured deep...into prairie soul" by explorers, missionaries, settlers, mounties, and the CPR (van Herk 1984a: 16). Like Ana /lstoric, I'laces lar from lillesmere generates alternative literary and historical genealogies for 
lost women Moreover, van Herk engages in similar revisionary work on language, genre, the historical process of naming, and historical settlement narratives as does Marlatt. However, Haces liar firom lillesmere marks a paradıgmatıc shift from a historical to a geographical context; whereas Marlatt deals with women's alienation primarily from a historical context, van Herk focuses on women's marginalization in literature as well as history, through the geographic tropes of vantage, viscera, and nomadology .

The highly experimental Haces liar from l:llesmere marks the life and geography of its author/narrator, ${ }^{i 4}$ who moves historically and autobiographically through the Canadian prairies to the northern reaches of Ellesmere Island, where she engages in a feminist reading of a Russian realist novel. The narrator, at once literary critic, autobiographer, archiver, explorer, and present-day nomad, plucks a character - Anna Karenina - out of Tolstoy's nineteentl. century novel by the same name, in order to revise Anna's story, and in so doing. the real and fictive inscriptions of women in general. Central to my consideration of Places fiar from Flle'smere is how van Herk theorizes a politically and ethically responsible feminist-postmodernist reading and writing practice - what she terms a "geografictione" - through which to engage and revise traditional inscriptions of female identity.

i. I use 'author'narrator' to denote the simultaneously autobiographical and fictional nature of the second person singular narration of Places far from Flle'sm're', subsequent references will appear as 'author' or 'narrator' interchangeably, wiih this inherent connection understood. 
Phese forr from lillesmere is a text about the interrelatomship of subject and place. and about escaping the male-dominated literary landscape by learning how to read and write differently: "where, in this indifferent landscape, are the women...; where, in this landscape constrained by male vantage, does the woman writer of the prairies enter?" (van Herk. 1984a: 18). Just as Marlatt practices a resistant reading-as-rescue strategy of "she my l.ost (iitl, my Herome" in thm Hestoric (12), so does Places far l rom l:llesmerre rescue another "lost herome" (van Herk. 1990: 77)." Van Herk frames her text with the narrator's revision of the literary respresentation of female subjectuity in the nineteenth century realist novel. As such a literary revisionist project, Places liar firom lillesmere adhenes to a primarily "feminist critique" paradigm; that is, criticism which focuses on women reading." Feminist critique entails a "hermeneutics of suspicion.' whoch assumes that the text is not. or not only, what it pretends to be, and therefore searches for underlying contradictions and conflicts as well as absences and silences in the text" (Moi, 1985: 75-6)

A feminist reading praxis like that of feminist criticue is an mportant site of political struggle, which in the case of van Herk's project "begins with the realization that the literary canon is androcentric. and that this has a profoundly

" All further references to l'laces fiar lirum l:llesmere will appeal in parentheses by page number only

Showalter outlines a feminist critique poetics as the study of "stereotypes of women, the sexism of male critics, and the limited roles women play in literary history" from the perspective of female readers (1994: 255). 
damaging effect on women readers" (Schweikart, 1989: 25). Places far from l:llesmere is a metatheoretical account of literary reading, writing, and hermeneutic processes. Divided geographically into four "exploration sites," van Herk's project is about locating "a site through which to read" (141). Maces liar lirom lillesmere's chapters are structured around the narrater's search for a future "grave" "i" site in which to bury traditional plots and engravings of women, and in which to make room for co: extualized readings contingent on vantage and viscera. Van Herk's feminist-postmodernist reading practice entails a clearing of space for new subject positions for women through contextual responsibility, that is, responsibility for one's geographical, historical, political, gendered locations.

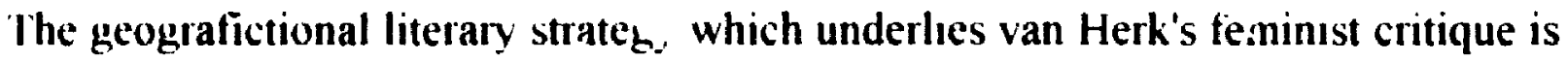
Olie of pragmatics:

The enormous weight of !nale story, male measurement, male domination. It's our turn to create some male Madame Bovarys and Anna Kareninas and Molly Blooms. Not appropriation but quite a different matter, a righting of balance, an equalizing of the scales [...] To revise the overall story, from our point of view: The visceral story (van Herk, 1991: 134).

Van Herk's primary concern, then, is to articulate "un/readings" of traditional inscriptions of women in such authoritatıve discourses as the literary tradition and history through the shifting junctures of self and place.

The novelistic genre and its constraints upon reading and representations of female subjectivity is a primary site of literary intervention in Places far from

"Grave' in van Herk's lexicon works on three levels, signifying: serious, the process of writing (as in engrave), and a burial site; 'plot' carries lue latter meaning, whi'e also signifying map-making and the action in a novel. 
l:lle'smere. The narrator is forthright about her distaste for the novel "You are developing a dazzling dislike for the good intentions of the movel, the 1 yy they insinuate themsclves into a perfectly miserable life and ty to cure it. the way they manoeuvre your reading" (104). I an Heri illustrates how the novel's depiction of female subjectivity is a culturali; and historically civ:tungent inventon

Anna's sexuahity ...eroticism, the power she exerts. culturally mis timed She has not appropriate colouration to suit the trappings of bourgeons respectability that...Karenin, then Vronsky, and above all Folstoy, wish to impose on her (107).

Yet precisely whose contrivance the nineteenth century heroine is temans unknown: "But whose invention is she? Tolstoy's" The numeteenth century ss? Russia's? The novel's?' Yours?" (113).

Through an "un reading" of the "corpulent Russian novel that pretended for so long to read the essential psyche of the passionate woman," van Herk daconstructs the prescriptive novelistic system (91). The novelestle gente is depicted as a prison in its representation of women, the only excape from which is Ellesmere Island, a place without trains

You must free [Anna] from the constraints of the novel she has been unprisoned in, shake her loose trom the pages of her owil story so she can float over the landscape here in this landscape of woman, this northern body (131).

The train is a metaphor in Ilaces liar l-rom l:llesmere for the uncominomising male trajectory of the novel, which results in displacement/death for female characters: "[Anna] ...is placed on that tran by Tolstoy, and you know that he uses 
trains to displace her" (133) The narrator refuses any sucl permanent plot, however. "You search out possible sites for your future grave.. But you suppose it will never happen, the notion of a family plot" (140). Van Herk undermines tne novelistic plot's "under/riting" (141). "Iron writing" (142) and "rape": of female characters inscii d by men by freeing Anna through an "un/reading" on Ellesmere Island

The real novel (about Anna reading) begins, it is about you reading Anna, it is about all Annas and their readings of themselves. Here, on Ellesmere, you see now how reading is an alien act, such a strange activity beside the daily motions of sleeping and eating... Only the north can teach what reading means, and you are a woman in the north, reading a woman written by a man to whom women were a mystery, a man who did not know what Anna was reading, who pushed her frein one side of the book to the other, interfering, manipulative A northern: umread Anna (132-3)."

Ilaces fiar lirom lillesmere subverts the literary gente of traditional autobiography in addition to that of the novel. through second instead of first person narration, and through a multi-narrative structure Van Herk undermines the traditionally singular autobiographical narrative rrajectory by interrupting the central narrative of the author's life history with a critical reading of Tolstoy's Immo Kart'mun. The multiple narratives of Anna Karenina, the narrator, and van

. In a fascinating reading of Anna Karcmun van Herk reads Tolstoy's metaphoric rape of Anna through the action of hte peasant, whom she reads as Tolstoy's foil: "Al donin a horrtile nehtmare, which /Anna/ had had several umes... A litlle old mon with unke'mpt heard was leaming over a har of iron, doung soimelhung and multermg meamingless words in lirench, and - thes was what alwats made the mghtsmare so horrshle - she felt that theugh thes peasam se'emed wo ha paing mo altertion to her he was doeng something dreadful to her with the Irem" (Tolstoy 15: van Herk: 119).

"That Ilaces lar lirom l:lle'smere' is a "notthern" is clearly a pun on that populaı :enre known as the 'western'. 
Herk intertwine, as was similarly the case in . Am, Hoform with the narratives of Mrs. Richards. Ina. Annie. and Marlatt. The resule is a confusion of narratorial levels. where van Herk's reflection on her own position as a female author in the "kingdom of the male virgin"30" merges with a reading of Anma's precarious position in Tolstoy's novel. By subverting the traditional ' $I$ ' of autobiographical writing. moreover. van Herk practices an alternative life writing which displaces the centrality of any one story. Narrated in the second person singular. I/ckes /iar Irom l:llesmere makes an intervention at the site of the centerr!! 'l', the 'you' functioning to interrupt the discourse of self-representation by refusing any central autobiographical subject position (Gilmore, 1994. 45) The missing 'I' works in a postmodernist way to "deface the idea of referential existence of the sell" (Buss, 1993. 197). The story of 'you', who we can read as van Herk, the narrator, ourselves as readers, or women in general, is further decentered with another voman's story - that of Tolstoy's Anna. Van Herk's refusal of the centrality of any essentialist ' $\mathrm{I}$ ' in her narrative is a refusal to insert women into the traditional autobiographical plot or "well traıned" narrative, both of which consistenlly end for women in inscription into the ; ther/samt/whore, muses al!" configuration (van Herk, 1984a: 18). Moreover, the self-effacing 'you' for writing which is (pulte

4" In her essay " $\Lambda$ Gentle Circumcision," van Herk names the malc-dommated west "the kingdom of the male virgin," with 'virgin' being a pun on 'version', "The pun on virgin is deliberate landl stems from my position as a woman writıng in the west, the need for alternate readings of our texts Beforc I can write. I have to re-write the male virgins" (1986c: 268 ). 
clearly autobiographical, resists the barriers between personal and political, since 'you' points simultaneously inwards and outwards.

Van Ilerk illustrates the possibilities for inscribing personal and political countergenealogies of female subjectivity without falling into authoritative discourses of the subject, like that of traditional literary autobiography. Autobiography is a genre founded on the "master narratives of conflict and resolution and development. whose hero - the overrepresented white male identifies his perspective with a God's-eye view and, from that divine height, sums up his life" (Gilmore, 1994: 17). I'laces far lirom I:llesmere illustrates the impossibility of autobiography for a feminist-postmodernist position intent on deconstructing any singular subject positio: and reconstructing multi-perspectivist subjectivities. Van Herk's refusal of the autobiographical 'I' in Places Far From fllk'smere is a literary political move in keeping with an anti-essentialist feminist-postmodernist agenda."

In place of the authoritative literary discourse of the novel, which aims to delimit female identity and experience, and autobingraphy, which attempts to neatly "sum up" a life, are van Herk's feminist reading and writing practices

"That Place's liar lirom lillesmere' effectively escapes novelistic and autobiographic generic boundaries is evident in how llaces far from lillesmere contınues to confound reviewers: one critic describes the text as a "geographically located. feminist-literary fantasy" (Kirkwood, 1991: 29), while another expresses bewildernent at its experimental nature: "What is this work? Certainly not a novel, not exactly an autobiography, although the speaker's name is van Herk and its history apparently that of its author" (Beer, 1991: 36). 
through which to inscribe alternative genealogies for women. Reading is an act of resistance in I'laces liar lirom l:Ilesmere. a shaking and punching against "rampaging male egos" who create self-indulgent characters, and then beat them into submission $(80,117)$. Van Herk practices a compassionate, "friendly" feminist revisionary reading strategy sumilar to that by Marlatt in .Ins I/ssfortc, a reading-as-rescue: "This Anna needs a friend, a woman friend, a reader...tker paginated presence makes you want to rescue her, offer her alternatives. Read her again. give her a second chance, another life, a different fiction" $(112.77)$ Van Herk's proposes a visceral reading practice; that is, a reading engaged from the expansive regtom of woman (as represented by lillesmere). A vicceral reading entails contextual responsibility for one's vantage, not to be confused with etther "inflated male visceras" or any essentialized female vantage (80).".

In contrast to the "terrible violation of an iron writung." like that of Anna by Tolstoy, van Herk proposes a political, ethical. compassionate reading practice in which the reader takes contextual responsibility for her readings "reading is a new act...not introverted and possessive but exploratory, the text a new body of self, the self a new reading of place" $(142,113)$ In opposition to the "barc-faced superficiality" of uncontextualized teadings, I'lece's l'ar firom I:Ile'smere's narrator practices a "whole" reading: "re/reading her, in lillesmere a/new, reading her

*2 That van Herk's region of woman is not essentialıst, however, is clarified in her essay "In Visible Ink": "To invent a women's world. Of course, no woman's world is clear and one-dimensional. The multifarious experiences of worren diverge, expand. suggest, differentiate, refuse to be lımıted" (1901: 132-3). 
whole, you can re/write her too" $(93,83)$ Such a whole or embodied reading is more than academic, it is also passionately engaged in a desire for justice: "She will not be read except she be un/read, and only love or the passionate reader can do that for her, not moralistic and sharp-nosed critics who evaluate/weigh/judge her, find her so much wanting" (131).

Van Herk's revisionary reading project in I'laces fiar from L:llesmere is "to solve a problem in the (grave) differences between men's and women's writing. [t]o investigate viscera and mirrors: passions and polemics" (82). The narrator finds that the significant difference between male and female writing and reading practices is one of vantage: women tend to write out of their own visceras, whereas men's visceras are "larger and more dangerous, hidden... in an inflated selose of themselves cente.ing the subject of greatness" $(80-81)^{4:}$ Van Herk finds that it is the "visceral obesession of men," in both history and literature, that needs revising:

the entire history of literature, the narrow, 'objective' reportages of men, concerned with their private victories and fears, their megalomanias and neuroses, their lies and their pride. Literature as a game of power and domination, as a gamble for 'greatness' (van Herk, 1991: 131).

Consequently, van Herk works to both redress the fact that women have been "always and forever culpable. exiled for their visceras" (82-3), and to expand the possibilities of female subjectivity beyond the narrow visceras of home,

"Van Herk recounts how Rudy Wiebe "once insisted that the reason women will never be GREAT writers is because they do not set themselves great subjects. 'women write only out of their viscera'" (80-81). 
domesticity, and the overdetermined identutess of mother, salut. and whote "By streiching the borders of the region we inhahit as women. we ane inducing hair-line cracks, fissures, in all the things that men have defined as the ter certory, or the larger world" (van Herk. 1987b: 3: 1986b 71 )

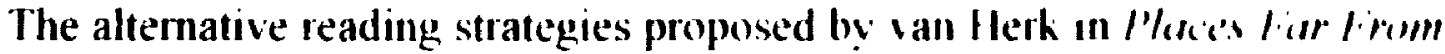
Lillesmere are founded in landscape at $t$ are ultumately a question of vantage and viscera:

The impact of landscape on artist or artist on landscape is unavoidable. In landscape, however, the cruclal point is the vantage from which the viewer sees the world. One must look at landscape from within landscape What one sees is determined by position; the scente varies accordingly (van Herk, 1984a: 15 ).

Reading is a political, ethical, and compassionate at in I'laces liar lirem I:llesmere that requires one assume contextual responsibility for ones vantages "One must look at landscape from withen landscape What one sees is determened by position; the scene varies accordingly" (van Herk, 198.4a 15) lillesmerc, a metaphor for female vantage, offers precisely such a scape for escape from male vantage

Lake Hazen in the northern part of Ellesmere taught me 1o unreadng, the act of dismantling a text past all its previous readings and writmgs the landscape there, its delicious remoteness, calm unmeasurability, calalyaed my reading act into something beyond reading, enabling me to untic all the neatly laced up expectations of words and theor pronting, theor arrangement on the page, the pages bound together into a directioe narrative, that then refused to be static, but turned and began to read back, to read me, to unread my very reading and my personal geography (van llerk, IW) 4) 
The readıng process's contingency upon vantage is imaged as varying gradations of light: "White nights, their bending of the day into a different figuratıon, a time without dark, beyond dark" (96). Van Herk illustrates how reading is a question of context by contrasting the manufactured light, darkness, and shadows of the cities with the twenty-four hour light of the north: "Reading in this clear green light an act different from reading south under the sanctimonious permission of fluorescent and incandescent fixtures. Reading changed by the quality of light it partakes of" (123). The twenty-four hour light of Ellesmere serves as a metaphor for enlighlened readings of and by women: "Within this endless light, she resists all earlier readings...In this light, every letter, every word. is sharper than it reads down south" $(121,111)$. Darkness, in contrast, is a metaphor for preconditioned, murderous, overshadowed read' ..gs, like Tolstoy's of Anna: "He shadows her unto her death" (107)

Van Herk's proposed reading strategy entails not only a rereading of the authoritative literary discourses of autobiography and the novel through Showalter's femmist cutique poetics, but an intervention into the very linguistic and semiotic discourses from which the genres themselves are constructed. Whereas Marlatt's linguistic deconstruction is etymologically based, van Herk practices a dissecting technique, whereby words are broken down into units of meaning in order to "un/read the language" (91). For example, 'woman' is transformed into "[ ]man" to underscore women's representation as absence in 
language (105). In another example, 'informed' appears as "in, formed." in the context of "archaelogies are (II))formed by those who (iil)vent them." in order to stress the insertion of the writer into his or her narrative $(58)^{\text {th }}$ Through a poststructuralist practice of word dissection, van Herk illustrates how words, the very material out of which our histories and fictions and ourselves, as women, are constructed, are themselves fraught with male vantage, which van llerk reformulates in language as: "I Jman". P'luces far from lille'smere' sustains an intense level of interrogation of language in order to uncover the polyvalence, what Beer refers to as the "double mapping" of words (1991 36). "l Inder/riled," a pun on 'underwrite,' is just such a doubly-mapped word. signifying the literal writung of Anna under the train (141). 'Train,' 'plot,' and 'yrave' are thee of the most pervasive multivalent words in van Herk's lexicon, the lattet two of which signify as both literary terms - the action in a novel; engrave the process of writing - as well as burial sites.

Fllesmere is similarly polyvalent; not only the actual name of an Arctic island, it translates into the English to mean 'their mother," or whis ran Herk refers to as "woman as island" (77) Ellesmere is a significant landscape linguistically. so distant it is "beyond language" and "speaks Its own firmmar of stone and tree, water and sky" (84).

HWhile the linguistic transformations van Herk performs throughout flede's liar lirom lillesemere are too numerous to cite, here are just a few other examples "a/void" (103), "des/scribement" (113), "un/read" (121), "re/read" (83), "dis/criminate" (54), and "dis/surface" (101) 
extreme Arctic, beyond all writing and its romance, beyond the intellectual comprehension or the geographical experience of most of those people calling themselves ('anadians. I am simply here, reduced to being, breathing the ice-crystal air through my nose and into my lungs, stamping my feet against the granular snow to revive my circulation. I am at last beyond language, at last literally invisible (van Herk, 1991: 3).

l:llesmere is a site "virtually untouched by language" (van Herk, 1987b: 14), and thereby a site from which to "un/read" the male-vantaged language which continues to "under/rite" women (91).

Combined with a revisionist reading and writing practice that is situated at the junctures of feminist critique and postmodernist aesthetics, is van Herk's equally feminist-postmodernist engagement with postmodern historiography in order to challenge the authoritative discourse of history. Ilaces liar lirom I:llesmer' is a historiographic metafiction which conflates the plotting of history with that of fiction, and in so doing dismantles traditional historical and fictive narratives in order to underscore the nexus of self and geography as a necessary vantage in any reading or writmg. As an instance of historiographic metafiction. Places liur lirom l:He'smere inhabits that space between personal and political, real and maginary. Van Herk sets historicity against fictiveness in the writing of her personal history as well as in her feminist criticism of Tolstoy's novel, in order to stress the importance of contextual, historical responsibility. At the same time however, van Herk de-authorizes official, permanent history in order to illustrate the arbitrariness and ultimate rhetoricity of all representational discourses: "memory insists on metal tags and wooden cubbyholes (20). Van Herk dismantles 
the traditional separation betueen the personal and the political by the very arrangement of the text: three chapters detailing the author's narrator's personal life history precede her subsequent reading and criticism of tmma Niur'mm

The process of history-making. like its literary comnternart, is revised firom

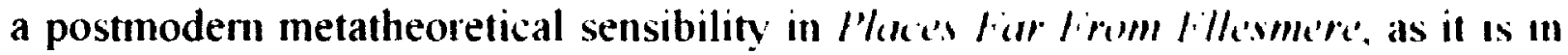
Marlatt's Ano Historic. Van Herh engages postmodern histornography in a metahistorical treatment of her own life history as well as that of the citles in

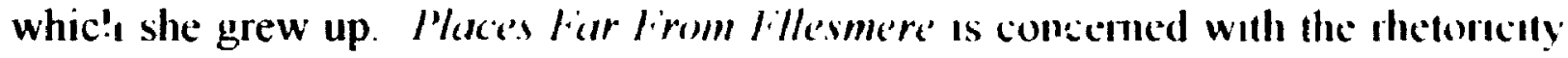
of history, and how history proves to be founded on those vantages and visceras which have to date been predominantly male. In van Herk's text, history is in longer an authoritative ontological discourses nor a reflection of reality, but like fiction, a system of meaning production through story listory II I'/acen liar Lrom l:llesmere transforms into metahistory, a highly contingent discourse whoch positions itself at the junction of geography and self "all places with acts of reacing as their histories" (36). The epistemological perspectivism central (o) postmodern historiography concurs with feminist revisionaly sllategles, by offering feminsm the opportunity to contextualise, politicize, and historicise the historical production of women.

The authority of history and its power to definitively name, orgamze, and explain reality is a site for intervention in I'laces far firum t:ll'smere, as it was in Ana Hestorks. The history into which the narator intervenes is the settlement 
hıstory of the prairies, a history of namıng. "Recorded history...the promise of names held and used and recorded" (60). Naming is Illustrated as having been a predominately male prerogative in the ('anadian west, a powerful history-making process in which women have been suspiciously absent:

These names, every mapped configuration male/lineated... Name, name. leave names on everything. on every physical abutment, leave behind one's father's name, the names of other men, the names of absent and abstracted/ideal women. Anna, has she an island or bay, an inlet? Is there an Anna Karenina cape in Russia? Don't ask how many Tolstoy inlets there must be (88).

Van Herk recounts the names of those people, all of whom are men, whose vantage defines the west: missionaries, explorers, early settlers, mounties, surveyors - all "li|nevitable writers. After realism, history, revolution, rebellion; eulogrzing saloons and cemeteries, churches and police barracks. Men. Male vantage, advantage. Rearranging prairie to suit their particular vantage" (van Herk, 1984a 16). Henday, Henry, Macoun, Deville, Tytrell, Chief Factor, Rowand. Thompson, Fidler. Boucher de Niverville. Brisebors. Macleod, and Ilardisty are among the men who have named. archived. and historicized the cities of the narrator's life. Having partitioned off the west, "everywhere picket fences fencing out the prairie...the neat divisions of denizens," these men have attempted to permanently engrave themselves in and upon the land, their names on cuerything from rivers and budges to streets and towns (67). Yet even this setllement history of the west. engraved as it is in the land, is nevertheless as mutable and impermanent as dust "All the names have changed now." just as the 
cety of Edberg slowly erodes - "The stationmasters house abandoned the creamery: crumbled. The teacherages hauled andy...The bus garage needs growing beside" ( $84.3(1)-32)$.

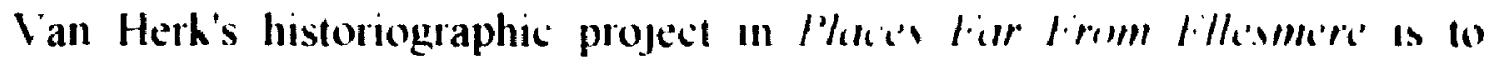
discover "[h]ow to read through, past this male histonographical fiction". how to read from a vantage "|f]ree of the graspings of most of | |man's umpositons, his history or fiction or implacable dess scribement. [wo|men esther real or invented" $(83-4,113)$. The answer lies in countermemory, in locating altemantuc histories "There must be another name, somewhere, if one only had the eyes to lead it" (97). Through the same postmodernist structure of palimpsestic mertevtualu! employed by Marlatt in fha Historic, van Herh "re-contextualizes the past in a new context" in order to raise the pertinent question of whose history, from whose perspective, is being told (de Toro, $1994+27$ ) Is an mstancie of palmpsestic intertextuality, Places lar l'rom l:llesmere mounts van llerk's Iwentieth century feminist version of fuma Karemm, rewritten from the vantage of Amm, ove Tolstoy's original from the nuneteenth century Numetous excerpts fiom the original are included, only to then be subsumed by van Herk's new version

Settlement history, moreover, is itself a palimpsestle "writmg over" of the land Before the official recorded history of Ellesmere Island by the likes of liclden and Nares, for example, van Herk insists on the possibility of another name "Forty-two hundred years ago humting bands roamed beside the inlets and fjords of 
Hazen Plateau. They had a name for Ellesmere, you are sure of that" (98). Places liur firum lillesmere undermines the authority of history by illustrating how history is a question of advantage, nothing more than a reading of place inscribed by those who have had the power to name: "in 1852 the island was named...for the Larl of Ellesmere. Why? Had he given them money?" (97).

Similarly, the writing of the narrator's own life history is shown to be a series of constructions contingent upon the vantage frum which she remembers and reconstructs them: "In such uneasy souviences, do you remember or forget? Or is it all an elaborate fabrication. the village of Edberg and the farm two miles south and two miles east part of a puppeteer's gesture pulling the strings of source?

(15). Van Herk illustrates how even her own revisionist histories are, like fiction. a (juestion of construction through remembering and forgetting:

Ldberg: this place, this village and its environs. A fiction of geography/geography of fiction: coming together in people and landscape and the harboured designations of fickle memory. Invented: textual: un/read: the hieroglyphic secrets of the past (40).

The authority of history, then, is as temporary and impermanent as "cupped hands lewhing water or sand":

You try to hold it in your hands, Edberg. cup your hands to enclose this soft jumble of houses and streets... How to kindle between two palms the train's arrival and departure... You cup your hands to hold it in... You look away: it moves, un'reads itself again, a sl; alteration leaving you puzzled and groping for reassurement... You check with other originals, ry to compare your grainy photographs to theirs...Impossitle: their versions negate yours $(34-7)$. 
The settlement history of the west. like that of van Herh's life. is wont to different versions, as street names are renam.d and old buldings give way to nen ones (70.30-32) History "re news its presences" accordang fo whom 11 is naming.

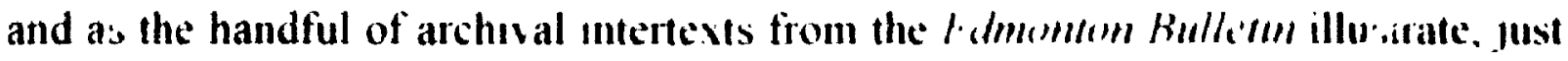
what makes history is highly arbitran " In effect, an Herk illustrates that the traditioral separation between history and fiction. private and public. needs to be rethought Whale the narrator destres to archuc her history "l dberg goes on with its falling, one molecule at a tme and you too in you ache to alchere it there to read remember blame To unhinge and to carve with words" .. she nevertheless accepts the provisionalit! of any stor ( "the wind makes this a duviv city your archaeological longings tlung into your eyes ;o!!), aliu that all histories. including her own, are determmed by landscape, lantagc, and vecera "It's been said before archaeologes are (in)fomed by those who (in)en them" (58).

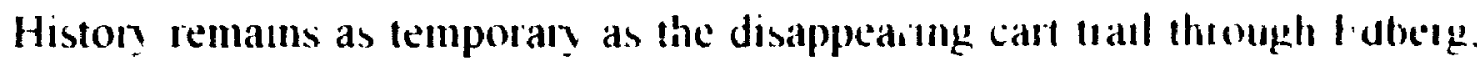
now "a scant etching through the bush, vanishmg" ( 30$)$ I an H.,l. formulates the constructedness of history and reading through a pohtics of vantage and wecta The subjective nature of history is imaged as thawing loe in summertme on Ellesmere island: "htindreds of tiny pleces orbitting in endless lloat" 1111 ) The

1" In one particularly banal extract from the archives of the $1:$ dmomlim Bulle'un, for example. we find a record of the number of lades aftending a dance and what they were wearng ( 51 ) 

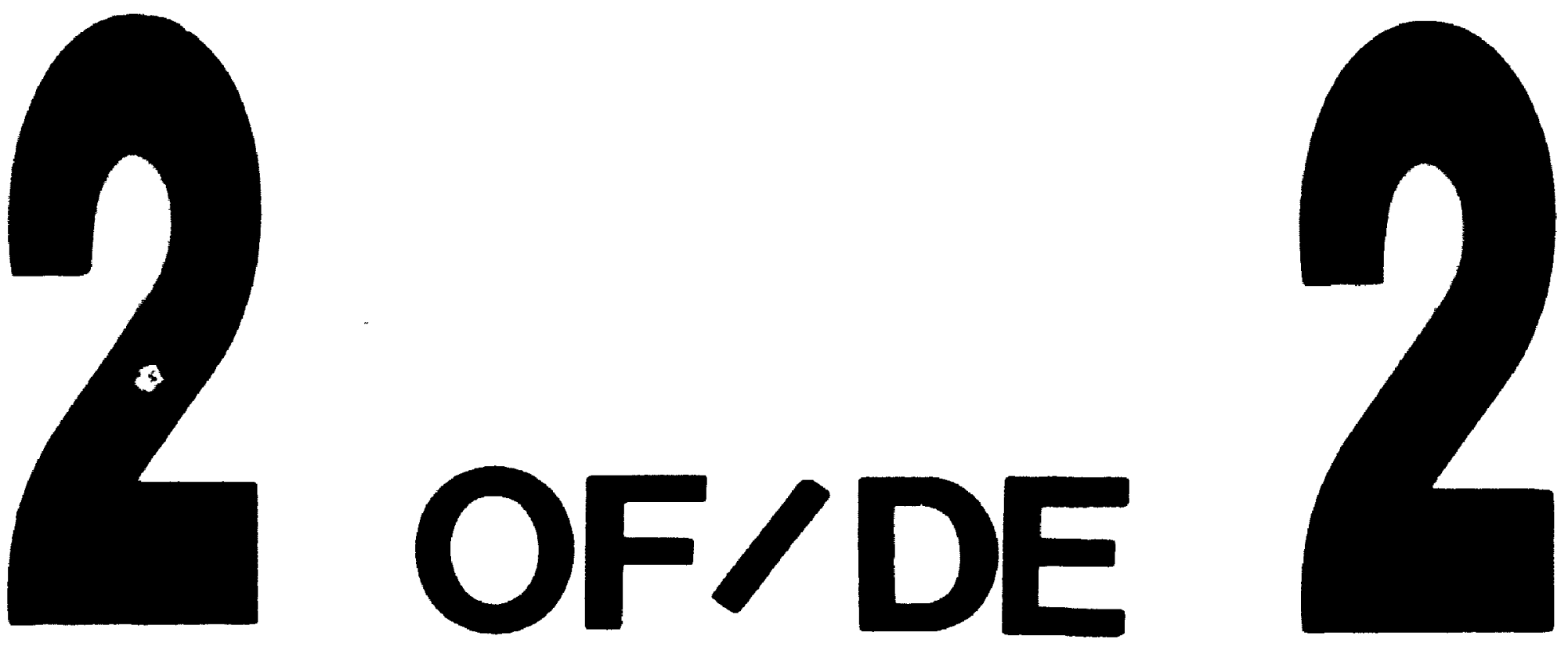

PM.1 3' 2 ' 4 PIOTOGRAPHIC MICROCOPY TARGET NBS $1010 a$ ANSI/ISO \#2 EOUIVALENT

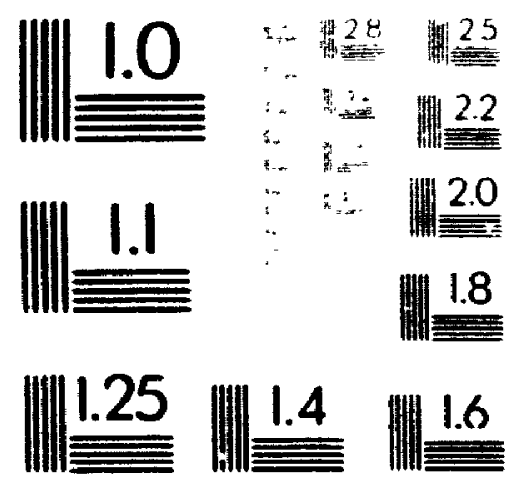

PRECISIONSM RESOLUTION TARGETS 
configuration of any one version of history is lihened. moreonet. to a jgsan puzzle: "The words are stirred. mined. like pieces of a ligsan. broken up into then separate shapes and the whole picture lost. liff to be reconstructed by another. a different hand" (113)

In addition to utilizing postmodern historiograph! and ats literan component. historiographic metafiction. to trouble the separation letween historical. fictional, and autobiographical discourses. Ian llerk uses the postmodern conceit of nomadology to permanently open the sign of female subjectivity. Labelled a "geografictione" to underscore its theme of the reciprocity

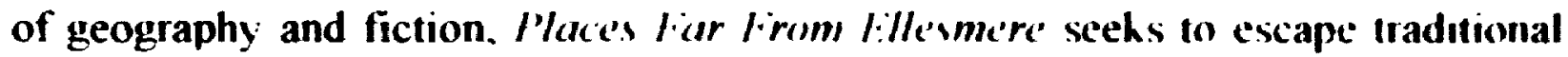
inscriptions of women in order to allow others to emerge through a politscs of geografictione, viscera and vantage. Ellesmere Island. "that inost northerly of extreme Arctic islands... remote of all Canada's island nock $A$ s far as it is possible to get away." promises precisely such a deterritorialized vantage for such escape (van Herk, 1990: 77,89)." Positioned "beyond the reach of all interference, all authors and bookings," Ellesmere is a landscape which offers unconditioned readings: "These un/read islands, these Annas all. Inexplicable, these northerns belong to no nation, to no configuration of [wo]man They are Annas, impossible to possess, determined to enact their own vitality" $(139,125)$. The cties which th That Ellesmere is comprised of the double feminine 'they' (women) and 'mother' is significant, and resonates with both the title of van Herk's chapter -"Ellesmere, woman as island" - and the cover material, where a map of I:llesmere is figured in the shape of a woman. 
have figured largely in the narrator's life - Idberg Edmonton. and (algan - are landscapes marhed by dowrs. walls. borders. fences. and stone Fdberg "six square blocks fof $\rceil$ fence post boundartes marking their rusty decades". (algan "a labyrunth of stone a cat's cradle of encapturement picket fences fencing out the praure. fencing houses from themselves and each other": and Edmonton a "fort(ress)" (13.19.74.73.67.43) In contrast to this labynuthine geography of encapturement characteristic of the pratric cities stands the "unread tundra" of Fllesmere "Her island. tabula rasa. away ness so thoroughly truant you have cut all connexion to all places far from Ellesmere" $(77$,

Landscape and its impact on the artist and reader are central to van Herk's project in I'ince's liar lirom IIll'vme're. Which is to dismantle traditional narratives of female subjectitity. and replace them with those of the multi-perspectival nomad ${ }^{4}$ A feminist-postmodernist theory of the subject entails a transition from the hegemonic discourse of the unified self to "a discursive network of representational practices" (Gilmore. 1994: 19). Van Herk envisions a multiplicitous female subject through an appropriation of the nomadic legacy of ranchers in western Canada for both herself, the narrator, and Anna: "Where is home? But from the outside, as early [wo]man a nomad wandering the prairie? Nighingale east, moving west toward only a cleft in the hills, no evidence of city"

* Coldman reads Maces far lirom l:llesmerce through Deleuze's and Ciuattari's theory of nomadology in "Earth-Quaking the Kingdom of the Male Virgin: A Deleuzian Analysis of Aritha van Herk's No Fixed Address and P'aces far lirum lillesmerce." (1993a). 


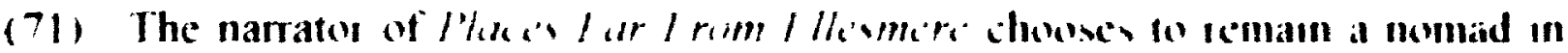

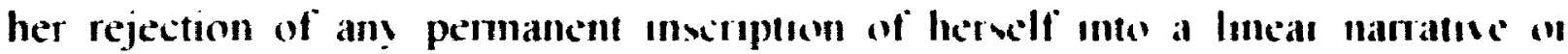
novelistic plot "Fransient the nomadic legact of the ranchers llome is a movement, a quich tuy at itself and it packs up ( all yourself a lav and consulf a map" 169$)$

Braidottis theory of femmins nomadism proves an interdiscursice openumg between feminist and postmodemist agendas regarding subjectivity. and concurs

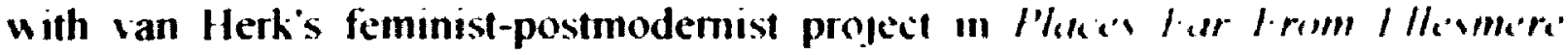
Simultaneously locating and dislocating female subjects as nomadic puoves the necessary negotiation between feminist and posimodermst de- and reconstructionist agendas for the subject. one which leaves the sign of limale subjectivity permanently open. but nonetheless gender-marked

The central issue at stake here is how to aroid the repetitıon of exclusions in the process of legitimating an alternative femintst subject" How to avoud hegemonic recodification of the female subject. how to keep an open-ended view of subjectivity, while asserting the political and theoretical presence of another view of subjectivity" (Braidotti, 1996: 418)

Female identity as nomadic opens up the possibility for alternatıve female subject positions. nomadicity entailing a flexible and pluralıstic posituoning for the female subject; one which escapes essentialism but stıll leaves room for alternative subjectivities. A "feminist nomadic position." notes Braidott, "can allou for... different representations and modes of understanding of female subjectıvity (") coexist" (1996: 417). 
Ian Heik i nomadx: subject. Without a set plot or narratise in which to be permancontly "en grased". is maged geographically as the thifung ice on I ahe

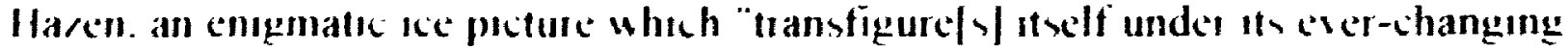
cloak of ice Ihe clothed lahe. watershin. sometimes a solid coat of white. sometumes in rages and talters. sometumes only wisps. faint promises of lice ceturnmg (112) The transformation of ce from winter to summer to winter is a metaphos for the animmed possbulities for a wandering female sabject "This ice pucture enigmatic, fascunatung. a portratt of Inna herself $1111-12$, Illesmere's chameleon nature. Its "slon wash and float. its conundrum meltung and reappearance." signifies the muluplicitous but localized female subject positions "this landscape of woman. this northern body a tloatıng polar desert for all characters to emulate." 188.78 .1 .111

The thawme ice on Illesmere. likened to a jlgsaw puzzle. is the pervasive trope used to signify new strategues of exploratory readings in addition to that of female subjectivity "Marmıng. the puzzle-1ce in the lake begins to melt itself into open patches. push itself around ..Summer on Ellesmere Thaw. a purc' reading" (93. my italics). The ice metaphor further sigmifies the provisıonal nature of any.

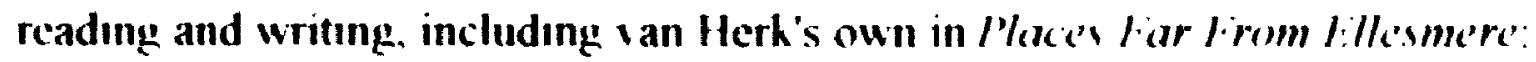

Knowing that this story. all that is written. can be un read. uninscribed. The words are stirred. mixed. like pieces of a jigsaw. broken up into their separate shapes and the whole picture linst. left to be reconstructed by another. a different hand (113). 


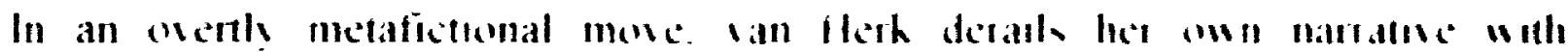
postmodermost perspectust doubt

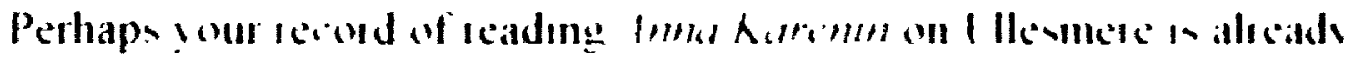
whtten. alreads un read But you have never been we close to failume under a versoon of train. that grubby das line: from t dherg indents

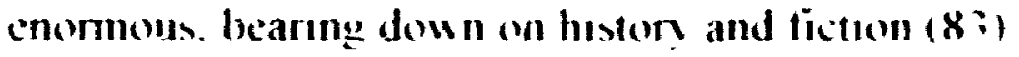

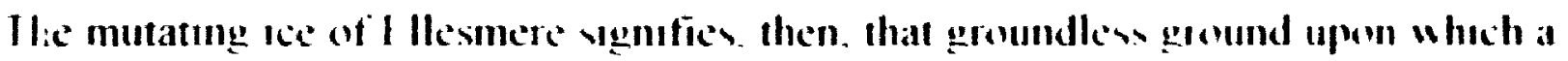
polntical. ethical femmost-postmodemest postem iclices

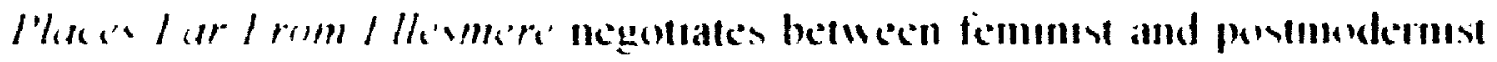
subjectivities in its smultancously de- and reconstructumst agenda reganding female subjectuity (nitiqung hiteray representatums of women. like that of Inna in the noneteenth century realist novel - "a self-mdulgent chatacter created by a man who couldn't imagne women enactung anythung mone interestug! than adultery or motherhood Prescripted chonces mothers. samts ar whomes" (81) wan Herk reads altemative possibılities for Inna. like that of a self-educaled. Well read woman whose "sevuality eroticusm. the power she everts. | was| cultually mis timed (107)

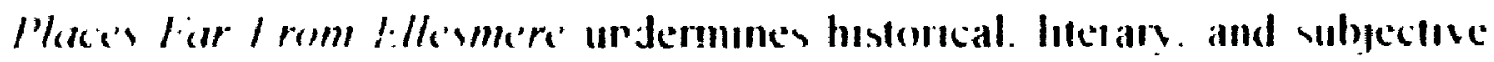
discourses and replaces them with alternatice untung and reading practices. reconceptualized from the "untrained" Iantage of I:llesmere Island, a scape which promises escape "Fllesmere is a happy island. happy in ifs strange remoleness. ils inaccessibility Lnaltered much by I I man" (122.105) A politics of Iocation is 
being auare of and responsble for the places from which one w reading. writung

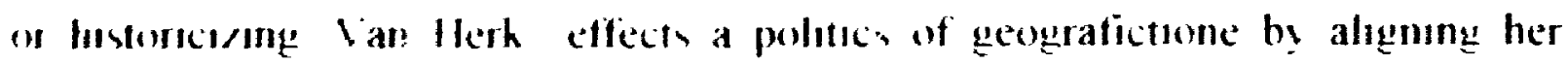
reading of Iolstor with that of her inn history and geography "You want to read sourself an a mirrori." and bs contevtualizing her criticusm of Iolstog from the santage of Illesmere Island 182) Van llerks shonce of "geogratictione" to

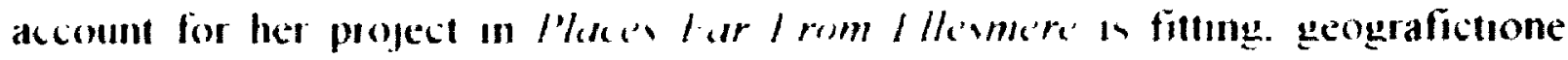
being a cartographe term for a writung practice stuated at the jurictures of history. geography. and the imagnation 11 hat is more, a politics of geografictione marhs the assumption of contextual responsibility for one's life and fictions "You must lise up to your fichoms. all there w to it. you must help ?ourself acheve gecografictuones of the soul" $(87)$

The comples trope of breaking ice on Fllesmere Island stgmfies the rupture

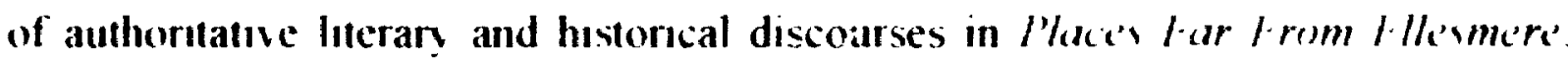
Traditional literan and historical representations of female subjectivity are resisted from the deterritonalized space of Ellesmere Island (Goldman. 1993 207). Van Herh combines postmodernist aesthetics $u$ th a politics of geografictione and a femimist pravis of compassionate and contextually responsible reading. in order 10 sustam an active interiention into authoritative discourses which claim ontological and epıstemological superionty. Haces lar firom lille'imere is about getting "out of line". Ian Herk reconceptualizes historical and subjective discourses from the interstices of meta-feminist theory and postmodemist cultural 


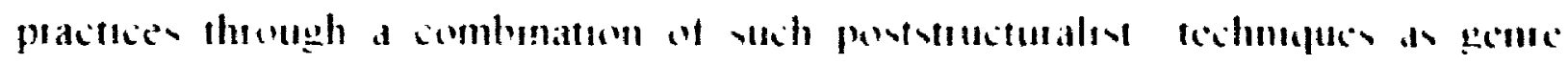

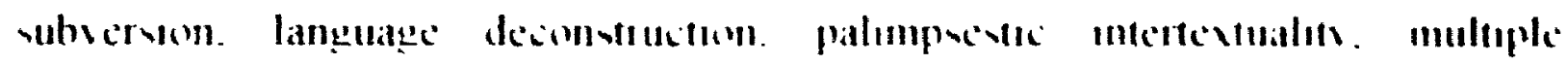

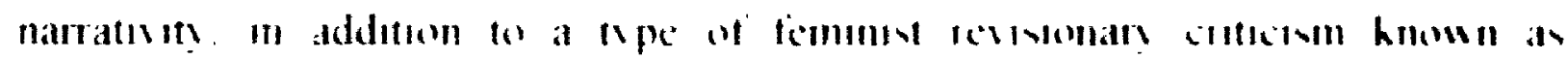

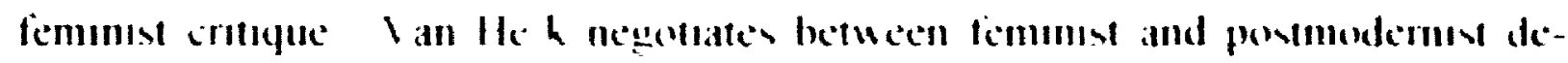

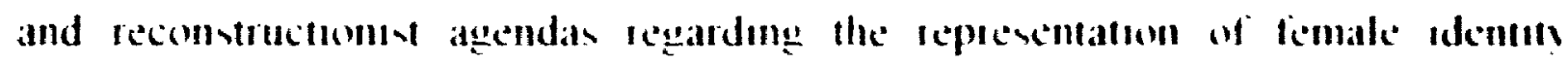
through a geographical trope of nomadicts. moncoser. by wohtmg in a contmumu

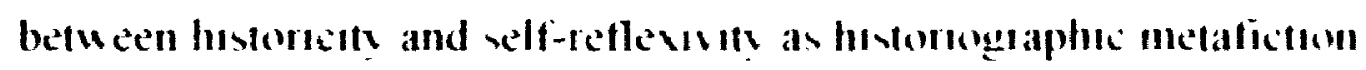

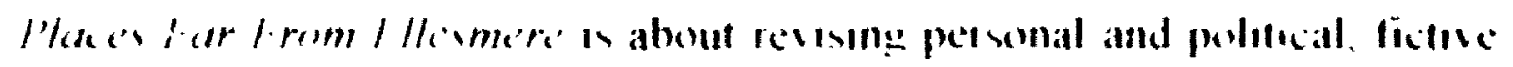
and histoncal decursivites though a polhtic of location - what van Herh names the geografictume of antage and weera Thus when the narraten ashs "Whese portrant is this"." 1221- we can answer that it is a geoup portrant of the multuple possibilutes for inscriptions by. for. and about women 


\section{( hapter 4: The Poetics of Prow ling and $C$ old $W$ ar $W$ riting in Kristjana (iunnars' The Prowler}

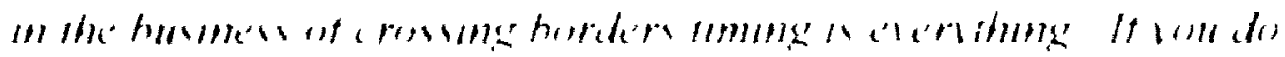

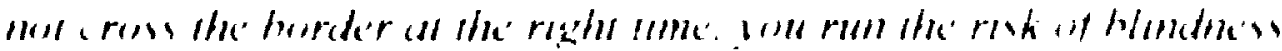

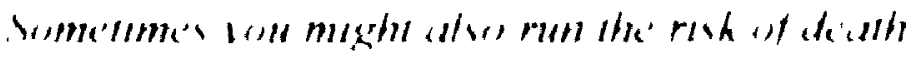

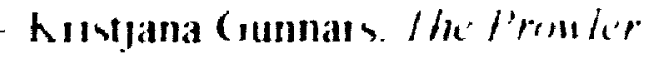

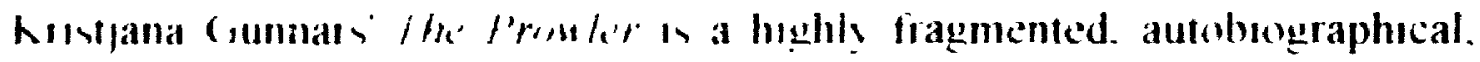
and selt-reflerme melange of stores about identsts. naton. politus, and war The fiammg narratue 1 that of the narrator (iunnars recollectung expertences of

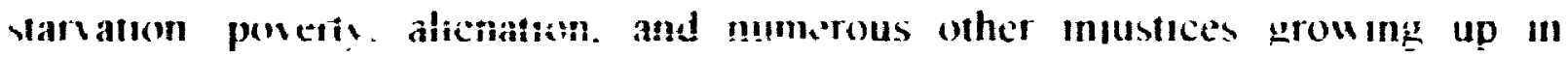
lecland durng the cold war. and her subsequent experiences of non-identity as a cross-heritaged woman both home and abroad in Vonth tmerica The political history of lceland. international cold war pohtics. fary tales. historograph. and liferary theon are a few of many narrative threads in /he Pronlis. where all Hones are onershadowed with another frammy ston the umpossibility of stones III general

Ihe liowler resonates with. but also differs diamatically from. the specifically women-centered femmst criticism of Marlatt and san Herh Whereas

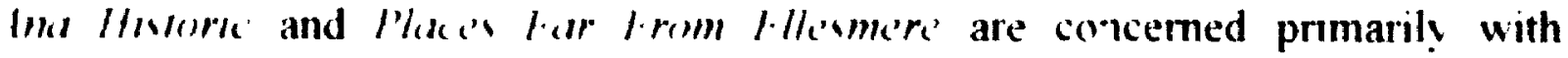
openung up the possibilities for fimall' subjectuity through alternative positionings of gender. (homolsevualıt. and geography. establishing space for altemative "rituig and representational practices and with a feminist critique that works to 


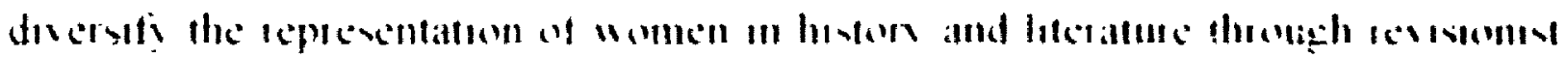

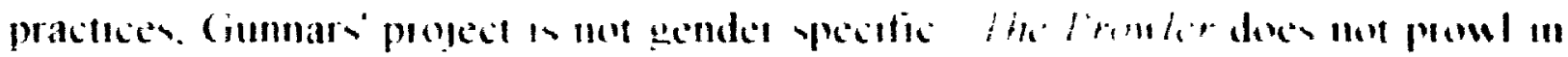

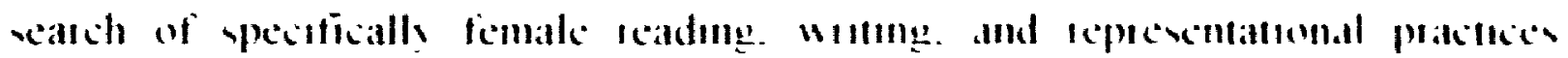

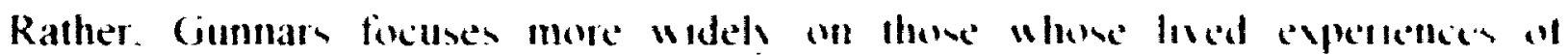

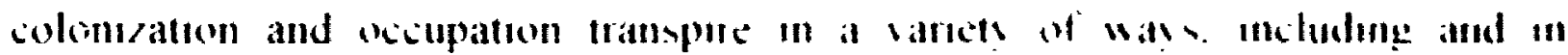

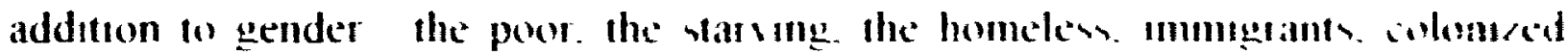

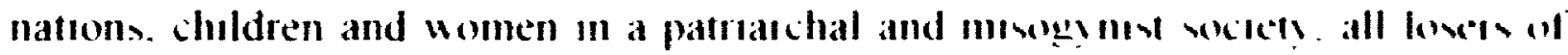
some wat ot wher

However. there is indeed a pronouncedly femmint poltheal ancenda to

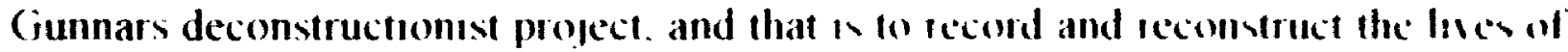
the history less aganst the threat of erasure. fo kell amotiner stor?

The ston is always somewhere else i unagme a book that pretend to teli n official story In the marguns there is another story li in incidental, it has little bearing on the official ston. but that is where lle real bous is (17)

the l'rowler works withon a femens framework to reconceptualse the place of absent subjects - the "losers" in wars of class. ethmonts, gender. and natron in history and language, through an assemon that the personal is indeed polltical. and that the unofficial stories indeed make sense "some stores matter and others do not It is not certain what makes one story more stgnficant than another Perhaps It is a connection. a hint in the story that there is a relation in 11 to a hroader perspective" (129) 
(iunnars' project in /he f'row/er thus resonates with the femmnst agendas of larlatt and van flerk not only on the bass of a hared postmodermist aesthetles of doubt. but also on a femmot front The s particularly the case when considering a reading of (eunnass ientmotif of the proulet and the dislocated expenence of the immigrant as representatue of the lived female experience "Homen are to some deglet immigrants es ery where" (199) 58) In an interview. (iunnars describes the

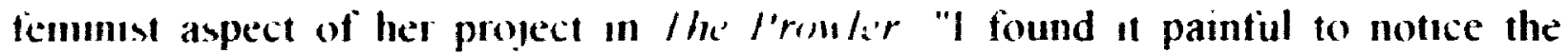
persistent invalidation of women's expenence, and children's expenence for another The voce of powerlessness is what intrigued me" 1199151$)$ However. (iunnars femmost framework is markedly understated in companson to those of Ian Herk and Marlatt Whereas Marlatt and van Herk explore processes of reading and writıng primanly from a position of gender. Gunnars politicizes reading and writıng paradigms from a multiplicity of positıonalities. Including that of gender. all of which share a common state of "occupation" femmism $\mathrm{m} / \mathrm{h}$ ' Iromler opens into identity issues in general. to an exploration of how identity is ascribed from outside. much in the sense of $w$ artime occupation

The complevity of identity is complicated from the start in Ihe Irouler. with a narrator who is multiply oppressed as a woman. an immigrant. and a person of "mived" Icelandic and Danısh heritage Gunnars shows hou difference is dehumanized on multiple fronts. on the bases of such ideological constructions as gender, class. age. ethnicity, nationality. and language. Ihe Irom/er's 


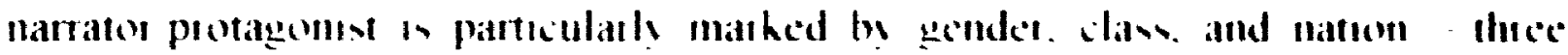

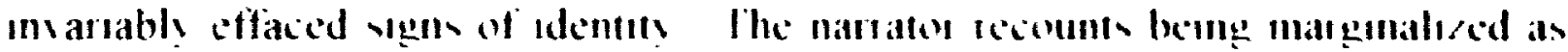
an unmugrant in both of hes "homelands"

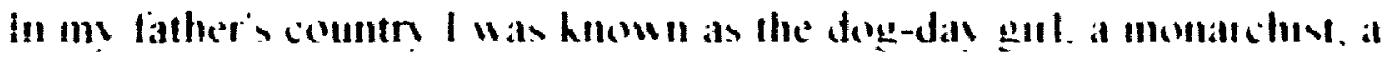
Dane (Mher kids shouted after me hing-rag! Bean' In my mother' evuntry other hids corcled me haughtsh ow theat bescles They whispered among each other on the street comels that I was at white Inuit. a shark-catel the kelander ( Io)

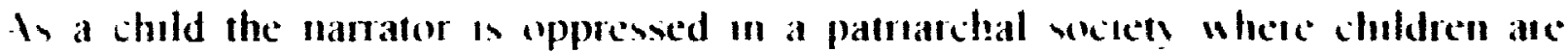
taught silence and submission to adults "It was not a country where chiden w."te ashed what is your name" Instead we wete aske! who owns you" Ihe pouper

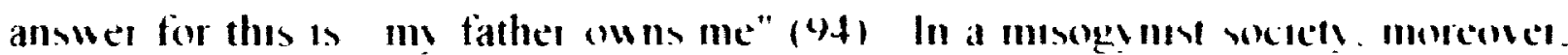
the narrator is oppressed on the basis of her gender "In a country where chalden were not taught to be proud. and where gurls lived under the matomal suspmen of

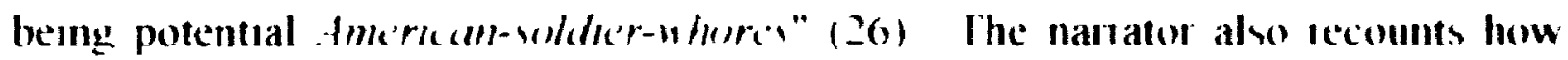
leelandic women's identity in fiction arises out of the national fical and theat of sevual abuse they faced as children "l glv novels appeared, wotten by lcelandic men. about women who were traitors" $(45)$ As a child. moreover, the nariator is aluays identufied as "other" according to even the xchoof children's sicuctal organization. "I was the last to be casted because I fell into no calcgory" (65) Another of the l'remler's stories of occupation is that of the sexuad abuse of gurls by men. a story which is doubly marked by the abuses of wat and colomiation 
The nanator recounts the ston of young fcelandic grils sexually threatened by the occups ing Imerican ann!

Imerican soldiers are interested in children When we were bathing in the fjord. the barrack-gurl and $I$, an American soldier suddenly appeared behind the rocks. He stood looking at us for a while. and I carefully deliberated what to do nevt The young man sard to me in American English: I've lost my watch Would you help me find it? $(13,80)$

Ihe Irow/er trespasses through literary and historical domains. committing

numetous tiansgressions along the $w$ ay as it steals across borders separating femmist and postmodernist. personal and politrcal. historical, autobiographical. and fictue discourses. Spanning two continents, larious wars. and numerous sories of imperalism and oppression. /he Prow/er's central natrative is that of the author narrator protagonist's childhood in occupied Iceland, Denmark, and subsequent immigrant status in tmerica. Ihe 'rowler is a metatheoretical account of the narrator's mecupted condition as immigrant. woman. child, and writer. and about escaping such literary, historical, political, and gender occupations The l'rowle'r is about opening up the possibilities of voice for the voiceless, and writing those who have been written out of language and history back into existence, agannst the immment threat of murder erasure. Tahing place in between places, between geographies, nations, wars, and identıties, and between literary forms, languages, and theoretical positionings, $1 / \mathrm{h}^{\circ} \mathrm{Prom} / \mathrm{c}$ r moves in a decidedly femmıst-postmodernist rhythm of de- and reconstruction. The text oscillates 


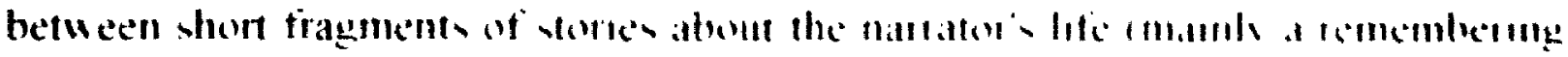

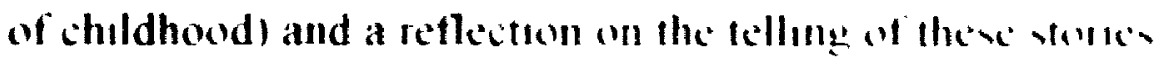

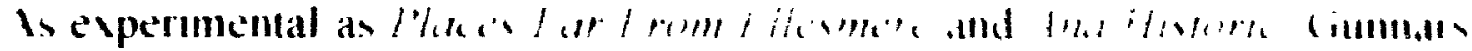

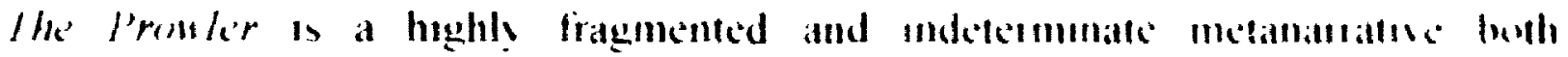

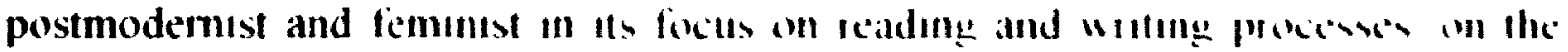

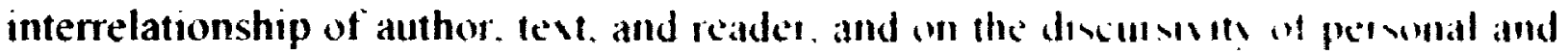

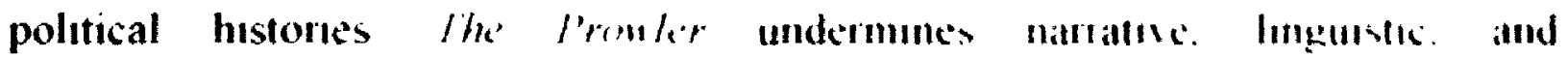
epistemological authority in the novet and works to decometruct the hicrachical textual system of author-text-reader. leaving in its place a radicallh demociatucel writing and reading practice. The reading to follow focuses an how /he lrmither

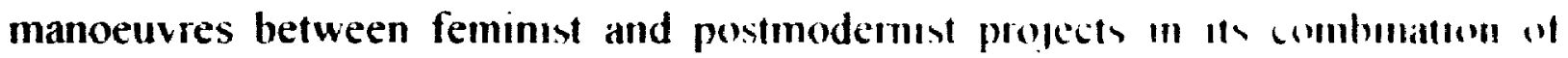
poststructuralist textual strategles with politically and ethicall engagered finmu: practices.

Through a combined practice of postmodern historiogiaph and metafictionality, the rhetoricity and discursivity of persomal and political lastorics is depicted through the narrator's selectne. self-censoring memony iciumals.

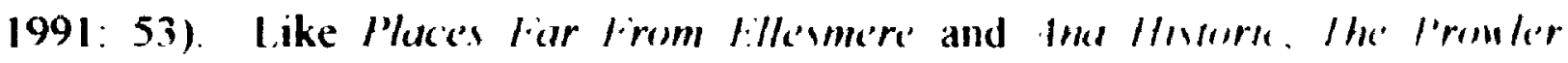
deconstructs authoritative literary, historical. and subjective discouses through a metatheoretical treatment of history and literature via a historiographic metafictional writing practice As such, the narrative depends on history t*vell as 11 doubts the authority of any history. "There is a tacit acknowledgement in writung 
that stories that are true and stories that are false mirror each other" (Gunnars. 1989: 162) ${ }^{48}$ The Prowler underscores the fundamental rhetoricity of history: "There was no order to history. Fate took random turns" (119). Memory becomes a large part of history in The Prowler, where the narrator likens remembering to running ink "Memories of early childhood do not come easy. There is only a sense of warmth, and all recollections run together. They appear on a kind of drying paper, where the ink seeps out of its channels" (131). History is shown to be selective like memory and subject to undererasure:

I did not know I was embarking on a year that I would subsequently try to erase. I gained a vague understanding from my year in America that all stories contain a level of undererasure. A certain urge to blot themselves cut. A fear of imprisonment (135).

The metaphors for the discursivity of history include those of an uncompleted puzzle, a deck of cards, and a tumbled cardhouse. The fragmented structure of The I'rowler - "the writer expects rough seas. The entire work may find itself on the floor in the end, again in shambles" (120) - embodies the dissolution of any master discourse, literary or historical, and advocates in its place an epistemological perspectivism, or situated knowledge. In another trope. history is paralleled to a detective story, whereby one searches for missing clues: "There are stories where everything that is written is a clue...It is a detective story. The reader thinks the enemy must be found. There are clues. They must be

* All subsequent references to The Prow/er will appear parenthetically by section number alone, since there are no page numbers. 
pieced together" (51.47). Elsewhere. history is likened io a game of cards and the random shuffling of the deck: "The text acknowledges that there is a search. The same game is played several times with different results" (146). History and the reconstruction of it through memory are shuffled anew by the author/historian at every reading/remembering/game:

I have sometimes thought: it is possible there is no such thing as chronological time. That the past resembles a deck of cards. Certain scenes are given. They are not scenes the rememberer chooses, but simply a deck that is given. The cards are shuffled whenever a game is played. The same game may be played several times. Each time the game is played the configurations are different, and a new text emerges (81).

The underlying agenda for the implementation of this metafictional code of writing is to effect a politics of location. Historiographic metafiction's simultaneous self-reflexivity and historical groundedness promotes contextual responsibility, whereby the text and author disclose their historical, political, and subjective contexts. For example, the narrator offers various versions of her childhood in Iceland - "In another version of my childhood, I did not grow up in my parents' house at all" (97) - as well as alternative readings of "Hansel and Gretel" and "The Ugly Duckling". The Prowler makes a game of perspectivism. relating real and imagined possibilities of the narrator's childhood. In one account, the narrator imagines for herself an alternative history: "I conceived of a desire to belong to the sea. To have been born on a ship. There were attempts at rewriting history" (106). 
In contrast to these metatheoretical reflections on history and fiction, there is a very material record of history in The Prowler from the perspective of the voiceless: the poor, the starving, the children, the girls and women, the Icelandic people in general. The history of colonization, occupation, and war figure extensively in The l'rowler, where the narrator recounts numerous crimes and wars: the Danish trade monopoly on Iceland ("As a result there was not enough food. The population decreased. Faces, I was made to understand, began to repeat themselves with greater frequency" $\{126\})$. ihe Russian occupation of North Korea, the German occupation of Denmark, the Russian invasion of Hungary, the Cold war, the Cuban missile crisis, the Vietnam war, Danish colonization of Iceland, Danish occupation of Iceland, American occupation of Iceland, British occupation of Iceland. On one narrative level, The l'rowler is very much the story of war and imperialism:

I do not thmk this is the story of a starving nation... My sister was so thin her bones stuck out of her sweater. She had sores on her hands. It was some form of malnutrition...At school we received CARE packages from the United States...there was no fruit, and there were no vegetables...we had very few clothes (9-10, my italics).

The Prowler, like Ana Historic and Places lar lirom Ellesmere, is marked by personal as well as political histories; consequently, it is autobiographical or life writing about the movement of life into story. In this sense we can speak of Gu.inars' text as autobiographical. ${ }^{+9}$ The Prowler admits the collusion between to This is not to concur with Buss, however, that the text is an autobiography. In Mapping Ourselves Buss argues that The Prowler is an autobiography which 
personal and official histories. between vision and version. subject and object Gunnars underscores the inevitability of the autobiographical in all fiction: "It is a relief not to have such rules. To play such games. llide and seck. Nor to have rules perhaps means you are free to steal from lomerself. 1.molly" (59, my italics). In this way Gunnars' project assumes a "politics of location" (Borsa. 1990). and intersects with Haraway's "situated knowledge" (1991) by aligning the historical. political, and autobiographical: "I did not have the proper Tin-drummish distance required for a story" (83). Elsewhere Gunnars notes: "all writing is life writing" (Gunnars, 1991: 51). The Prowler thematizes the subjectivity of reading and the inevitable movement of life into writing through the image of text as mirror: "I conceived of another sort of self-portrait: the painter paints her own image. but paints it directly on the mirror. The viewer sees not the image of the artist, but $\mathrm{ms}$ own face through the lines of oil paint" (111, my italics).

labels itself a 'novel' "to protect it and herself from all the baggage the word 'autobiography' carries in traditional definitions" (1993: 197, my italics). She critiques van Herk's choice of "geografictione" for much the same reason. Buss argues, moreover, that naming generic locations as she does with The Prowler is a "necessary literary/political act" (197). I suggest that Buss misses the "literary/political" nature of Gunnars' project in The Irow/er, however, in such a traditional genre-specific definition of a text which so clearly sets out to undermine systems of genre in general. Conversely, Gheorge refers to The Prowler as "(auto)biographic metafiction" (1991: 44). While I think this term certainly explains in part Gunnars' project in The I'row/er, and is equally applicable to Ana Historic and Places liar lirom l:llesmere, I prefer historiographic metafiction, within which the autobiographical as well as the historical is implied, since it is writing which underscores the relationship between historical contexts and individual circumstances. 
(iunnars writes against historical and literary textual traditions in a text "that refuses to play its own game" $(81)$. The traditional logocentric textual system is based on the construction of author, text. and meaning as sovereign subjects (Greene and Kahn, 1985: 26). Gunnars' project in The l'rowler is to dismantle the textual system and its atterdant conventions (illusions) of objectivity, truth, and authority. The Prowler marks an opening up of the system of signification by reconstructing the atsthor-text-reader relationship into a non-hierarchical one, where all three (rather than the author alone) collude to produce the text and meaning: "The writer cannol escape repression. The text represses the writer. The text is the writer's prison. The words will not take the writer into themselves. The author is therefore locked out of the book" (93). Just as the author's authority is extremely relativized, so is the text autonomized as it speaks its own authority in The Prowler: "The story is likewise arrogant. It talks back, claiming for itself a certain autonomy. The story tells its exponent: you do not know me" (96). What is more, the reader's role shifts from that of a passive receiver of authorial meaning to that of an author in his or her own right: "The reader is new to being a hero. He is not used to this spotlight, to having books named after him" (111). Gunnars begins this undoing of the textual system by "murdering" the authorial voice through acute self-reflexivity. The Prowler thematizes Barthes' and Foucault's metaphorical "death of the author" in order to "do away with the authoritarian voice" that appropriates and colonizes (Gunnars. 
1991: 57). This death. as it were. is the ambiguous "murder" to which (iumnars repeatedly alludes in The Prouls'r. "Has any one been murdered"." "The question of the murder remained. there had been a murder recently. It was not hnown whether the prowler. whose presence had been noted at odd times, was also the murderer, or whether there were actually two crimma!s" (47.116)

The hierarchical textual system of authority is undone in l'h' l'rowler. where intertextuality, metafictionality, and mose e'n ahims are among the postmodernist strategies which function to undermine traditional generic modes ("games") of representation and epistemology. Intertextuality is an opening up of the text to other texts: "a revolutionary gesture...against the closure of the signifier" (Morgan, 1989: 261-2). Whereas Marlatt and van Herh primarily utilize a palimpsestic intertextuality, Gunnars employs a rhizomatic intertextuality, where there is an endless network of allusions to multıple sources, some of which are often undetectable. Beginning with an epigraph from Duras' The Iover, the text prowls through Gunter Grass' Iin Irum, the writing of James Joyce, Golding's Lord of the lihes, the Brother Grimm's "Hansel and Gretel," Hans C'hristian Andersen's "The Ugly Duckling," Saint-Exupery's I.e l'elll I'rince', and numerous Icelandic intertexts (of which the North American reader like myself is unfortunately ignorant), as well as the work of such poststructuralist theorists as Barthes and Derrida. Intertextuality implies a dynamic interrelationship of texts, an indeterminacy of meaning and a lack of authority or ownership over meaning 
by author and reader alike. That The Prowle'r reminds the reader self-consciously of its intertextuality is evident through such recurrent statements as: "The text tells all other texts" (69) Intertextuality works towards a perpectivist epistemology in The l'rowler, where the narrator and author reject the privileged position of authority and ownership over their text and its meaning: "It is a story that is read in time. It is not my story. The author is unknown. I am the reader" (119).

Gunnars deconstructs the legacy of textual ownership and authorial primacy, and radically transforms, in fact democratizes, the hierarchical relationship of author, text and reader through an aesthetics of play: "The writer gets a certain amusement out of rewriting old stories" (151). Author, narrator, reader, and even the text itself become firgurative prowlers "who chase narrative threads through other texts" (Gheorge, 1991: 44). The deconstructed textual system works to collapse any rigid distinctions between political, historical, and life writing:

The quest in literature is a mirror of the quest in life. It is possible to imagine a story where the protagonist is a reader, who is therefore also the author. It is a story where the boundary between that which is written and that which is lived rernains unclear (146).

While The Prowier is a story about other stories, it is also a story about itself. Metafictionality, like intertextuality, works to rupture any authoritative illusions the text might otherwise establish. Gunnars' is a metastory that continually foregrounds its metafictionality: "I think of a book that has left in the 
censor's words. A book that does not pretend it is not talking about itself III books talk about themselves" (6.3) The l'rowler illustrates its tevtuality repeatedly with metatheoretical comments like "The tevt admits this is how I am sewn together" (74). Assuming contextual responsibility for onc's historical. autobiographical. political. and geographical constructions means incorporating the story's untelling alongside its telling. Furthermore, mosi' in ahime. the work-within-the-work conceit, functions alongside metafictionality and intertextuality to exemplify the rhetorical nature of textual constructions The "imagerial equivalents" (Gunnars. 1991: 54) of the text embedded in the tevt, the mises en ahymes, include: the rhizome, the labyrinth. the knot, the game, the deck of cards, the cardhouse, the puzzle, and most typical of all - the mirror. As microcosmic versions of the text itself, each of these structures shares an endless deferral of meaning: "The structure can never close" (96). Take the purzle, for example: there is an unknown figure on board the ship that passes between Denmark and Iceland, named "the prowler" by the narrator, who assembles a puzzle in the dark. The assemblage of this puzzle and its "impossible lack of clarity" resembles the narrator's simultaneous construction and deconstruction of her own life stories textually:

The project was to clarify the picture. To make the patterns emerge out of a random set.

When the puzzle was almost finished, I saw it must have been a Monet. Something French. But we had rough seas. and one moming I found the tediously arranged picture on the floor, again in shambles (108) 
Like the text itself. the puzzle is simultaneously put together and pulled apart. and "there is always a chance that the entıre picture will slide off and shatter before the final pieces are in" (163)

In addition to poststructuralist strategies of intertextuality. metafiction, and mise an ahyme to rearrange the textual system. Gunnars also uses trans-generic strategies of genre subversion. Genre is portrayed as an obligatory set of tedious conventions in The l'rowler: "It is a relief to be under no obligation. Not to have to balance the books. Not to count the cash at the end of the day. Not to count the pages as they accumulate. Not to think about a climax or a denouement or an introduction" (28). In a much more pejorative metaphor, genre is liken 1 to a prison:

It is a relief not to be writıng a story. Not to be imprisoned by character and setting. By plot, development, nineteenth century mannerisms. A relief not to be writing a poem, scanning lines, insisting on imagery. handicapped by tone. A relief just to be writing ( 3 ).

That The Prowler is about trespassing the boundaries of genre is evident from the first page onwards. where Gunnars alerts the reader to the alternative writing practice to follow - "It is not writing. Not poetry, not prose" - and continues in this manner to foreground the text's generic uncertainty: "There is a disagreement about the nature of this story...it is possible that this is a crime story. It is also possible that what we have here is social realism. On the other hand it is much more likely that this is a love story" $(1,71-2)$. 


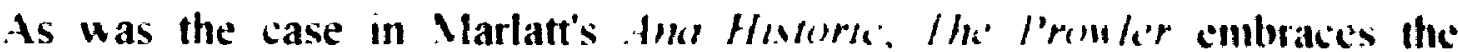
novelistic genre in a parodic way only to then subvert any such genre " Despute the label "a novel" on the front cover. It cuts across gente boundaries self-consciously:

There is an admission that duties have been shurked. That the text has been prowling in the reader's domain. Telling itself and then interpretung itself Incorporating that which does not belong to a story Posing itself as a question: it may not be a story. Perhaps it is an essay. (Or a poem. The text is relieved there are no borders in these matters $(164)$

The narrator admits that "It]he novel I at one tume intended to write rejected itself It began to talk about its own genesis instead The story disappeared In its place there was another story, an unexpected story. A great surprise" (6.3) (iunnars subverts the novelistic genre in numerous ways, the most obvious of which is through a lack of conventional page numbering: The Prowler is arranged in a distinctly aphoristic style in short sections numbered I through 167 Moreover. Gunnars undermines novelistic conventions by getting out from under the confines “) The Prowler plays with a number of other genres in addition to that of the novel, including the romance, the fairy tale, and the detective story. (Of particular significance is Gunnars' use of the detective genre, a popular metafiction code for thematizing the hermeneutic paradigm (Hutcheon, 1980: 71-2). (iunnars - nntinually impedes the text's search to "solve" or put things in their place through a parodic subversion of the detective genre. The detective story is typically a chronological unfolding of events which leads to the solving of some crume. Yet The l'rowler refuses to solve the crime: "If this is a detective story, the sleuth has been kept in the dark. The detective is not showing the cards. Crimes can be hard to solve. Especially when the crime has not been determined in the first place. There is only a suggestion that something is wrong, but the sleuth is unsure which of the stories contains the clue. There must be one card, one piece, that can be used to tip things off" (148). 
of the Iraditional beginning-middle-end linearity imposed by most literary frameworks. which induces the writer to move chronologically through time.

Beginnungs and endings are arbitran constructions in the frem/er "Where did it begun" Hou far bach can you take cause and effect until your ston starts |sfomewhere in all this, the story begms" $(6.11)$. The l'rowler ends with the begunning, in a sense. the final scene figures the narrator's newly married parents sallng from Denmark to lceland. an action that predates all that occurs in the text Ihe Prowler instead moves in a rhythm of de- and reconstruction: "There is a tug and pull between the linguistic and metalmguistic. the fictional and the metafictional elements of the narrative" (Gunnars, 1991 54). Gunnars underscores The Irowler's alinearity through the leitmotifs of a deck of cards. which is a randomly organized set of numbers. and the card game, which is played repeatedly with different outcomes. This randomness is inscribed on a structural level. moreover, where the text's division into numbered fragments could be read in any order. "I imagine a story that has no direction" (24). Moreover, there is a lack of conventional plot development and closure. some stories are never fully developed. the threads never teed up. and it is in this sense that The Prowler is "[a] card ga ne that did not add up" (2). Finally. Gunnars subverts the traditions of the novelistic hero and $h s$ quest for self-knowledge:

In literature, tradition instructs, there is usually a protagonist. The protagonist is always on a journey. If inquiries are made concerning the stories behind the story, the text yields to the pressure and gives up a form 
of an answer The object of the search is. we are told. a hend of hol! grat (146)

In keeping with her deconstructionst project. however. (iummans leaves no illustons intact "There never is a holy glatl." only "a bague that though the noods" (146,153).

Gunnars' postmodernist subversion of forms noths wilhm a femims paradigm of revising traditional plots for women. In an intervew. (iunnars detauls the feminist aspect of her project in /he l'ronler "I found it pamfiul to notse the persistent invalidation of women's experience, and children's expentence for another. The voice of powerlessness is what intrigued me" (with (iheorge, 1001 51) Amongs the novelistic plots the /rowler secks to excape are those of the murder - "I have noticed in a passive way that in literature, as well an in politics. only that which kills is thought significant. Only murder is taken sernously I imagine a te:s that does not kill" - and the romance "No more illussons, no mote emotional clap-trap. No more distressed lovers suffering the ironies of fale" $(129,90,86)$. Like van Herk and Marlatt, Gunnars is concerned with replacing traditional romantic novelistic plots with alternative writing by, for, and about women:

All stories are romances. Detective stories, spy thrillers, homror tales are all romances. They are not real. The romance of the threat The male romance.

I have heard speakers on the female romance. Sentimentality Iimotion Feelings of love. Fears of rejection.

I imagine a story that is not a romance (53). 
Ihe l'ruwler is a postmodern ston not only about the impossibility of telling storses, but like the projects of Ian Herk and Marlatt. Is concerned with finding neu ways to tell storles "There is a certain acknowledgement in this writung that there is an itmerary. A $x^{\prime} t$. A kind of fidelity desired" (95). Like Marlatt and van, Herk. (iunnars works to make room for women in language. to give volce to the wiceless through a poetics of naming "Much later in life 1 contrived a poetics of naming Only that which is named is able to live in language" (52) Gunnars opens up a space for the possibility of alternative stories to be told despite her poststructuralıst sensibility of doubt by playing postmodernism against itself. For example. she undermines her own deconstructionst project by attending to its own inherent ideologies. namely, those of the postmodern academic industry.

At times I think we have outgrown the story. He are no longer entertained by pretense. There is too much knowledge. Too much self-consciousness. There are always other stories, metastories. about which we have made an industry. Degrees offered, awards given, livelihoods supported for the deciphering of metastories (55).

Recogmzang that "[a] ston that does not desire pretense must incorporate its own metastories," The Prowler avoids rearticulating the very epistemological arrogance and authoritative structures it aims to subvert. Gunnars achieves this by assuming an epistemological perspectivism, where the possibility of truth is not abolished but radically relativized through contextual responsibility and permanent partiality (Haraway, 199!). 
Despite the fact that "|t|here are theorists who sal that all stonles anc lies All that is written is a lie There is no such thing as truth." and that "what is written is not excklly true." Giunnats mamtans that "none of the terstons is exactly a lie" (68-69, my ttahes) Thus while the narrator undermunes the official nature of any of her stortes, this does not preclude their being told cinsequently. many lived experiences, particularly those of the politics of oppression. arc impressed upon the reader in such a way that there is no doubt these viones alc "not exactly a lie". Ihe Prowler is in this sense the ston of a staning leclandic nation: "we received CARE packages from the I nited States thete was mo frut. and there was no vegetables" (10), and, the story of internalized hatc and oppression. with the sister's hunger strike against herself - "Mly sister so thin her bones stuck out of her sweater" (9). There are also the namator's stories of numerous childhood oppressions. stories of hunge: and cold ("We had wert lew clothes. I was always cold, and when it rained I was always wet Al mght I fell asleep shivering" (10\}), child labour ("In my father's country It was necessary for all people to work...[c|hildren worked in the school gardens roung boys carried newspapers on the streets...[y]oung girls were put in charge of infants" 1112$\}$ ), enforced silence ("It was not a country where children spoke to the adults (Only the adults spoke to the children. I could not say father, I am cold and need more clothes" $\{10\})$, and the story of sexual abuse of young girls durng the American cold war occupation of Iceland ("American soldiers are interested in children" 
(13\}). Moreover, the narrator recounts the oppressions of other nations as well, like the Hungarian boy who flees the Russian invasion "who was put on a Hungarian children's working crew": "He pulled weeds from railroad tracks all day. His only food was an onion sandwich, which someone else always stole and ate for him. For that reason he was very thin" (62).

Reading and writing are significant sites of feminist resistance in The I'row/er. Gunnars' text invokes a feminist-postmodernist reading practice whereby the reader as prowler must participate in the text's de- and reconstruction; where the reader as detective needs to search for the gaps. the absences, the missing pieces of the puzzle, in order to read the "derisive comments between the lines" (164). Reading in The Prowier "unfolds like a game that invariably goes beyond its own rules and transgresses its limits" (Foucault, 1984: 102). Gunnars incorporates both dialogic and rhizomatic theoretical structures into a feminist model of resistant reading and writing. In contrast to the linear, plot-driven narratives like that of the "male romance" (53), The Prowler proffers an alternative practice where "the female story is an unfolding of layers" (25). Gunnars uses a birth metaphor of a hatching egg, moreover, to describe this gender-marked writing: "Not to think about a climax or a denouement or an introduction. Instead just to watch the egg hatch. It is there and I know it will hatch" (28). In keeping with The Irowler's epistemological perspectivism and equanimitous tone, however, Gunnars invokes this feminist discourse of gender-influenced writing in 
a decidedly detached manner. suggesting gender is "incidental" even as she practices a feminist writing:

I have read treatises on male writing. The male line. The masculine story. That men have to be going somewhere. Men are always shooting something somewhere. And that women do not. That women can grow all things in one place. That the female story is an unfolding of layers.

I do not know if this is true. It is incidental (25).

According to Keefer, this ostensible contradiction, where the narrator oscillates between engagedness and apathy "doesn't erase the former axiom, but turns it s.deways, so that air and light may travel freely through it" (1995: 53), which is to say, The Prowler situates itself playfully between de- and reconstructionist paradigms. $^{52}$ The contradictory accounts regarding the nature of the text. moreover, follow Gunnars' dialogic writing practice: "There are so many people vying for attention in the telling of any given story that they cancel each other out. I imagine a story that allows all speakers to speak at once. claiming that none of the versions is exactly a lie" (68).

A dialogic paradigm of reading and writing intersects with a rhizomatic practice $^{53}$ in The Prowler, where the author is deauthorized as originator of

s The notion of the "male line" resonates back to van Herk, who also writes about "Man and his straight line - steel, yet - horizontal world cannot contain or even predicate the female curve of prairie" (1984a: 17).

$: \quad$ There are numerous examples of the narrator's contradictory descriptions of her text, most often when the text claims it is not what it is, such as: "I do not think this is the story of a starving nation" (9) when it clearly is, or "It is a relief not to be writing a story" and then a few lines later: "the story intrudes" $(3,6)$ "3 Gunnars' comparison of the text to a planted seed, in addition to numerous references to gardening and vegetables to describe Ihe l'row/er, intersects with Deuleuze's and Guattari's theory of the rhizome to explain interdiscursive, interdisciplinary connections in $A$ Thousand I'lateaus: "A rhizome ceaselessly 
meaning, and collaboration is admitted between history and fiction, truth and imagination. The rhizome is a plant structured like a root system which consists of numerous interconnected tendrils both above and beneath the surface, significant in that it offers "another way of travelling and moving: proceeding from the middle, through the middle, coming and going rather than starting and finishing" (Deleuze and Guattari, 1987: 25).$^{54}$ Moreover, the rhizome is

an indeterminate and endless network, where new tissues are inserted, keeping little or no relation .1. all with the original network, characterized by six principles: connection, heterogeneity, multiplicity, asignificant rupture, cartography, and tracing (de Toro, 1994: 420).

Rhizomaticity works as an alinear metaphor for alternative textual strategies of reading and writing in The Prowler: "a story that has no direction. That is like a seed. Once planted, the seed goes nowhere. It stays in one place, yet it grows in itself. It blossoms from inside, imperceptibly. If it is a vegetable, it nourishes" (24, my italics). Gunnars' rhizomatic metaphor intersects with another, Borgesian metaphor for a labyrinthine writing that "would take you into many false corners. It would be a maze, and you would not understand it. Repeatedly you would have to backtrack, retrace your steps, acknowledge defeat. Then in the end there would be an ironic twist" (28). Similarly, the text is affiliated with a knot: "There are

establishes connections between semiotic chains, organizations of power, and circumstances relative to the arts, sciences, and social struggles. A semiotic chain is like a tuber agglomerating very diverse acts, not only linguistic, but also perceptive, mimetic, gestural, and cognitivc" (1987: 7).

4 A rhizome is defined as: "a rootlike stem lying along or under the ground, that usually produces roots below and shoots from the upper surface," (Gage, 1983; 966). 
stories that apperr as dead ends. They go nowhere. They are knots in the fabric" (129). The textual metaphors of the knot. the labyrinth. the hatcling egg. and the rhizome signify a rigorous reading practice that is "discriminating" and "cxacting" (75). The very political nature of Gunnars' reading is manifested through an invocation of a cold war model to explain a confrontational writing that breaks out like war:

It is in the nature of writing to contain a note of defiance. To confront its opposite, to stare it down. To make a certain claim for life.

It is also a confrontation that looks in, for what is being defied is located inside writing. A form of cold war, where the ink that is directed into patterns is carefully watched so it will not spill over and spread out. uncontrolled (105).

The narrator's starving sister, a girl who refuses to eat what little food there is in the midst of a starving nation, is on a hunger strike against injustice, (iod, and herself in general: "She lay bone-thin on the bed, her cheekbones protruding, her eyes large. Why do you not want to eat? I asked her. People who refuse to eat die. She answered me. I just don't want to be who I am, she said" (18). The starving sister is an important character in terms of the relationship between voicelessness and writing in The Prowler: "There is a split in the women characters; the anorexic sister is an emblem of the lived experience of poverty as well as the female body's impoverishment" (Williamson, 1993: 106). The anorexic sister's gradual disappearance works as a metaphor for women's absence in patriarchal cultural constructions. The sister who does not write disappears, in contrast to the narrator, whose project it is to write herself, and her sister, into 
existence." Gunnars project is to write those who have been written out of the dominant discourses of history, literature, and language back in, against the threat of murder/erasure. It is in the context of this activist revisionist agenda that the text's epigraph, taken from Duras' The Lover, gains significance: "The story of my life doesn't exist. Does not exist. There's never any center to it. No path, no line. There are great spaces where you pretend there used to be someone, but it's not true, there was no one". As Duras' words suggest, The Prowler is about finding a writing in which to record the story of one's life and mark one's existence.

Identity remains a complex sign in The Prowler, and Gunnars avoids any essentialist positioning by acknowledging the diverseness of her own, and the narrator's, identities: "Perhaps the person telling these stories is a little older...The person writing these words is probably the one who sits beside hospital beds...[t]here have been so many voices" (17-19). Similar to van Herk's nomadic motif to signal the multiple possibilities of the female subject, is Gunnars' use of the multiply intersecting identities of the "cross heritage" person. Yet in Gunnars' case, this nomadicity is a state of occupation enforced from the fatrarchal regime. The Prowler works in a continuum between feminism and postmodernism, however, combining a postmodernist subversion of the Cartesian subject with feminist strategies of resistant reading and writing practices, to affirm previously censored personal, political, and historical stories of multiply oppressed subjects.

" In an interview with Williamson, Gunnars suggests that the anorexic sister represents her "deepest fears about simply not existing" (1993: 106). 
The narrator inscribes the stories of her life. at the same time remaining acutely aware of the discursivity of these stories. This postmodem metatheoretical strategy prevents Gunnars' project from falling into essentialist and epistemologically authoritative discourses of traditional autobiographical, fictive. and historical narratives, while still doing the much needed feminist work of inscribing histories from the vantage of the voiceless. By alternating between inscription and doubt, de- and reconstruction, Gunnars makes space for women without rearticulating the essentialism at the centre of the traditional genre of autobiography and the novel.

It is from the intersecting frameworks of postmodemism and feminism. therefore, that Gunnars illustrates how identity is comprised of a set of ideological constructions based on difference and vantage. Prowling is a pervasive motif in The Prowler, referring metatheoretically to processes of writing, reading, and hermeneutics, and on a socio-historical level, to oppressive processes of displacement, immigration, occupation, and colonization based on gender, ethnicity, nationality, and age. The prowler signifies numerous people: on a metatheoretical level, the prowler is the reader, author, textual characters, and the text itself. From a historical, political, and feminist framework, moreover, the prowlers include the occupying armies, the American soldiers that abuse young Icelandic girls, children without voices, immigrants without a language or country of their own, and women without a language at home or abroad. The prowler 
attempts to piece together the puzzle, build the cardhouse, find the path leading out of the woods, read the "novel". However, the prowler continually impedes her own "progress," or her progress is impeded for her. And this is the point of The I'row/er: to impede systems of progress with alternative, rhizomatic-like growths. The text prowls in search of a reader; the reader prowls in search of the missing clues of the text; the author prowls in search of her stories. In terms of hermeneutical and epistemological concerns, prowling implies a searching for something that is necessarily absent:

It was a long time before I understood that the point is an illusion. That portraits occur without center. In a puzzle every piece is its own center, and when compiled the work is either made up entirely of centers or of no centers at all.

In the metastory there are figurative prowlers looking for somethir.g. But there is very little for them to find (110).

The trope of prowling signals the identitylessness that the subject marked by marginalized identities experiences. Prowling is thus a metaphor for absence: one prowls for something one lacks. ${ }^{56}$ The prowler signifies. on one hand, the female subject and her place outside of literary and historical traditions. Prowling also describes Gunnars' task in The Prowler: to steal through traditions in order to make room for stories from the voiceless. Women are relegated prowlers by historical, linguistic, and literary discourses which continue to signify their

" To prowl is: "to go about slowly and secretly hunting for something to eat or steal; to wander or cruise about (a place)" (Gage, 1983: 905); "to stalk, hunt, sneak. steal. range, roam, slink, pursue, prey on, tiptoe, scavenge, plunder" (Roget's Thesaurus, 1977; 541). 
absence. The narrator, in particular, is a prowler who is invariably displaced wherever she goes, as a foreigner both at home and abroad, geographically. and linguistically. Gunnars' prowler metaphor resonates with Cixous' image of the feminist prowler ("voleuse") "changing around the furniture, dislocating things and values, breaking them ali up. emptying structures. and turning propriety upside down" (1976: 258). It seems Gunnars' prowler does exactly this:

Words are suitcases crammed with culture. I imagine a story of emptied containers. Bottles drained of their contents. Travel bags overturned, old clothes, medicine bottles, walking shoes falling all over the airport floor. To come to your destination with nothing in hand. To come to no destination at all (52).

In addition to being a metaphor for an enforced state of occupation, the prowling conceit also signifies a strategy of resistance. Prowling is an act of truancy (158). and serves as a metaphor for revolting against various textual, sexual, geographical, a -a historical regimes.

Gunnars negotiates between the de- and reconstructionist agendas of postmodernism and feminism in The Prowler, where we find a postmodernist deconstruction of history and the subject working in tandem with feminist commitments to historical and subjective transgressions and revisions. While the Prowler is thoroughly postmodern in its poststructuralist decentering of the subject, history, epistemology, and of novelistic conventions and plots which continue to delimit women's experience, Gunnars' text also involves a repositioning of the voiceless subject, the child, the poor, the oppressed, the 
immigrant, and the woman, in a radically relativized. but nonetheless historical and autobiographical narrative, a narrative which marks the historical colonization of subjects by gender, nationality, class, and ethnicity. Gunnars' project is distinctly feminist in so far as she works in The Prowler to "validate the self" in the face of linguistic, historical, and literary invalidation. Gunnars validates her experience as a child, woman, and immigrant through an acutely subjective narrative. The Prowler is a writing in and against what it means to be an immigrant, woman, and child with no place of one's own. Gunnars achieves this self-presence through a radically contextualized subjectivity: "the conscious, unapologetic use of the subjective - complete infiltration of the subjective - on the world" (Gunnars. 1991: 51).

Gunnars effects contextual responsibility through metahistorical and metafictional writing practice in which the author appears alongside her words:

In the metatext there is an acknowledgement that the consciousness is turned out wherever it desires to settle...Any subject is a contrived subject. The point of view is uncertain. The writer is necessarily part of the story $(98,120)$.

The l'rewler advocates a kind of perspectivism. where the sense we make of things is highly subjective: "Is there any reason to believe that the sense we make of things is good sense?" (30). In keeping with her nuanced position between feminism and postmodernism vis-à-vis history, reality, and trutin, however, Gunnars undermines a singularly poststructuralist approach to ontology and epistemology with a large dose of irony. She uses double entendre to undermine 
what seems on the surface to be a voicing of high poststructuralist nihilism with the material reality of her people's oppression and the very political significance of non-existence:

Some Icelandic novels make no sense. They are not meant to make sense. They go nowhere, refuse to grasp reality, say there is not reality.

Potentially there is no reality. My father's people have always known that potentially they do not exist (30).

The Prowler is politically engaged in its tackling of representation of the raced. gendered, and geographically oppressed and voiceless subject: "In the metastory behind the story that was never told, there is a hint of politics. The text allows for certain backdrops" (153).

The Pron'ler marks an "abandoning of the militancy of meaning" (Cunnars. 1991: 53). Meaning still holds currency; it is just that it is radically subjectivized. Gunnars' narrator takes responsibility for her context and the confluence of this context with her ensuing version:

Anything that is written necessarily has a point of view. The text refuses to give in to public demand, which insists it either have no point of view or alt points of view at once. This is what is called objective. The text is not objective because it is unable to be so and still be a text (141).

The Prowler registers the polysemicity of language with repeated allusions to Saussurean poststructuralist linguistics (Gheorge, 1991: 45): "Words are not what they signify. We confuse the signifier with the signified. Words are only words. They live in an atmosphere of their own" (52). As a child the narrator steals through languages and texts that she does not know, but are nonetheless less alienating than the languages she does speak: 
I read entire volumes in German, Spanish, Italian. without understanding a single word. They were simply words. with auras of their own... Reading in a language I knew, on the other hand, was a different matter. The added dimension of meaning appeared. Meaning was not always evident and always potentially terrifying (159-60).

Gunnars effects an epistemological perspectivism through the Saussurean recognition of the arbitrariness of language and meaning: "All that a story is, I thought, is a way of looking at things ... Everything. I to' \& myself, depends on the vantage point" (90)." The narrator of The Prowler acknowledges the constructedness of her rememberings, as such assuming contextual responsibility: "The writer is given to resorting to differently coloured light bulbs. Tn placing the story in an inappropriate light" (123). Gunnars diffuses the truth/lie binary, where "truths" are relativized, contextualized meanings: "Truth does not yield itself to its seeker. There is a suspicion that truth may not exist. Yet there is the certainty that what is being told is not a lie" (156).

Postmodem metatheoretical practices of historiographic metafiction, intertextuality, and mese en ahyme combine with poststructuralist linguistics and semiotics for an enabling aesthetics of doubt with which to transgress authoritative literary, historical, epistemological, and representational modes of discourse in The Prowler. Furthermore, this postmodernist theory works in conjunction with a very $" \quad$ Gunnars use of vantage clearly resonates with van Herk's thoughts on vantage in "Of Viscera and Vital Questions" (1991) and "Women Writers and the Prairie: Spies in an Indifferent Landscape" (1984), where van Herk points out the domination of male vantage in Westem literature: "Male vantage, advantage. Rearranging prarrie to suit their particular vantage... Where, in this landscape constrained by male vantage, does the woman writer of the prairie enter?" (1984a: 15, 18). 
material. historically and politically engaged project. and that is to record the markedly fragmentary and missing history, stories, and subjects occupied and rendered voiceless by misogyny, patriarchy. colonization, imperialism. poverty. starvation, and war. A dialogic and rhizomatic-like interaction of historical. literary, socio-political, and metatheoretical narrative levels in The l'row/er enables Gunnars to open up an interdiscursive dialogue from within both feminist and postmodernist frameworks, where a postmodernist aesthetics of doubi and a feminist aesthetics of lived experience, politicized personal histories, and situated knowledge. promote a worldly writing that is autobiographically marked and contextually responsible. 


\section{( hapter 5: Alternative Genealogies}

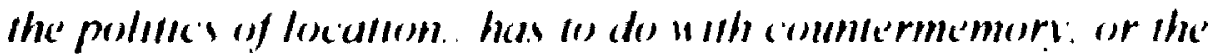
development of allernatrie' genealesgess.

- Rosi Braidottı. . Vomeshe Suhpjects

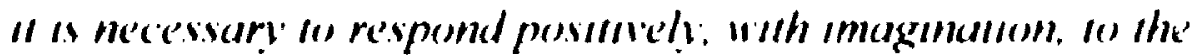

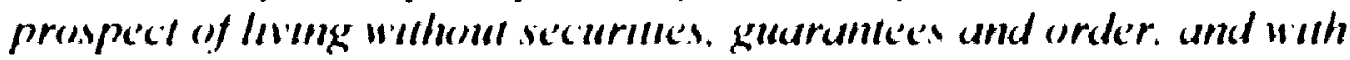
contungency and ambivale'nce'.

- Patricia Waugh. P'osimodermism A Reculer

There is a similar circling back to and from history in the projects of Marlatt, van Herk, and Gunnars: Ana Histork delves into the brief but obscure history of a woman barely mentioned in a Vancouver archive. Places liar lirom Allexmere rewrites the literary history of a famous Russian woman - Tolstoy's Anna Karenina; The Prowler tells the history of tarious wars and occupations from the perspective of the losers. These are texts which incorporate feminist. postmodernist, and contemporary histcriographic elements in their contestation of official histories and their creation of alternative ones. Marlatt, van Herk, and Gunnars raise the very political questions of whose history, from whose perspective, is being told. What does it mean to read and write as women within cultural institutions that regulate and authorize only limited constructions by, for. and about women? How do you write the history of the voiceless (The Prowler). of women now forever lost to the margins of history (Ana Historic), or of women overwritten entirely (llaces liar from lillesemere)? How do you inscribe 
alternative histo es when official History has always been "the historic wolce (voice-over). elegiac, epithetic, a domintshng glance as the lid is closed firmly and finally shut" (.tma Hwork 48)? These ate soune of the guestions that Marlatt. van Herk, and Gunnars approach through feminst-postmodermust. historiographic metafictional, fiction-theory fiameworks.

Historiographic metafiction marks a reciprocal concern with the "histoncity of texts" and the "iextuality of histories" (Montrose, 1902 flo) It is a writing which problematizes traditional historical knowledge while nonetheless msisting on the importance of the historical. As a paradigm which alternates between historical and metahistorical realities, historiographic metafiction is an interdiscursive space between text and world in which the much needed fiminst work of inscribing other stories transpires alongside metatheoretlical and epistemological concerns regarding stories in general Marlatt, van llerk, and Gunnars utilize this postmodern histoncal writing code to de- and rehsioncise female subjectivities in an alternative histoncal paradigm founded on epistemological and historical perspectivism.

In Chapter 1 the ambiguous relationship between femmssm and postmodernism was outlined, as arguments of opposition and allaance gave way to a third position of negotiation via the arbiters of history and the subject Negotiation involves a reconceptualization of binarial relationships, where feminism moves within the deconstructionist agenda of postmodern atshitics - 10 
uncover dominant ideologies - but also beyond this aesthetics of doubt, in keeping with an ethically and politically activist agenda to change oppressive cultural systems. The result of this negotiation was a feminist-postmodernist position: an interdiscursive framework which grows out of the paradigmatic crossovers between meta-feminist and postmodern practices, and is at once personal, political, and ethical.

Through a process of interdiscursive negotiation, then, feminism and postmodernism were combined into a politically and ethically responsible feminist-postmodernist framework, on the grounds of positionality and perspectivism. A politics of positionality or location permits the gender-marked subjec: to function as a strategic position from which to operate politically. For as Alcoff notes:

If we combine the concept of identity politics with a conception of the subject as positionality, we can conceive of the subject as nonessentialized and emergent from a historical experience and yet retain our political ability to take gender as an important point of departure. Thus we can say at one and the same time that gender is relevant because we are taking gender as a position from which to act politically (Alcoff, 1989: 323).

Postmodernism's aesthetics of doubt offers meta-feminism the opportunity of reconceptualizing the subject and history without falling into essentialist theoretical traps, through attention to contingency and location. Epistemological perspectivism provides the theoretical groundwork for a politically and ethically 
activist feminist-postmodernist position which refrains from rearticulating the very prescriptive discourses it seeks to subvert.

Having illustrated that postmodemist aesthetics can be incorporated into a feminist strategy of resistance in Chapter I. Chapters 2 through 4 proceeded with readings of the primary texts from the feminist-postmodemist framework detailed in the previous chapter. Each textual reading was directed by the central problematic of how "[f]eminist theory has joined forces with poststructuralism to challenge and decenter such previously unassailable and solidly centered entities as continuuias History and the rational Cartesian cogito" (Hutcheon, 1986b: 219).

Chapter 2 explored Marlatt's reading-as-rescue praxis for writing off historical representations of female subjectivity. Central to the consideration of Ana His:oric was how Marlatt engaged the postmodern writing practice of historiographic metafiction as a strategy for getting out from under the weight of history. Writing against a particularly limiting Victorian historical code of female subjectivity, Marlatt offered an alternative identity - that of lesbian - with which to challenge traditional nineteenth century inscriptions of the heterosexually-marked "normative" subject.

Chapter 3 moved from the consideration of history in the previous chapter to an intervention into literary as well as historical authoritative discourses in Places far from fillesmere, through the same postmodernist code of historiographic metafiction. Van Herk engaged in a "feminist critique" praxis 
which, along with a compassionate reading practice and poststructuralist textual strategies, suceeded in troubling the male literary tradition's inscription of women into the "mother, saint, whore" configuration with another possibility; namely, that of woman as nomadic explorer. From the central conceit of geography, van Herk opened the sign of female subjectivity through a politics of geografictione, contingent upon the tropes of vantage, viscera, and nomadology.

Marlatt's and van Herk's rearticulation of female identity from the contexts of gender, (homo)sexuality, and geography were further nuanced in Chapter 4, where Gunners' opened the sign of the subject on the multiple fronts of ethnicity, class, and nationality, in addition to gender. Central to the consideration of The Prowler was how Gunnars combined strategies of historiographic metafiction and historical and epistemological perspectivism with a politically and ethically engaged feminist articulation of the lived experience of oppression. Futhermore, how The Prowler illustrated that difference and identity are always a question of vantage, defined by the winners, and thus particularly effacing for the multiply-negated subject, was considered.

Acute metahistorical and metafictional self-reflexivity, the deconstruction of historical, literary, linguistic, and subjective cultural constructs, and the reconstruction of alternative genealogies, are all elements of the historiographic (meta)fiction-theory of Marlatt, van Herk, and Gunnars. Each author's construction of alternative genealogies combine the de- and reconstructionist 
agendas of postmodernism and meta-feminism, in order to move "from the negative hermeneutic of ideological unmasking to a positive hermeneutic whose aim is the recovery and cultivation of women's culture" (Schweikart, 1989: 35). As such, Ana Historic, Places far lirom Lilkesmere, and The Prowler avoid the dangerous illusions of objectivity and truth, while at the same time offering new provisional truths; temporary and radically politicized and historicized positionings for women reading, writing, and written.

Reading and writing prove "an important arena of political struggle. a crucial component of the project of interpreting the world in order to change it" in the projects of Marlatt, van Herk, and Gunnars (Schweikart, 1989: 24). Ank Historic, Places Far From Ellesmere, and The Prowler figure women reading and writing in political acts of resistance against those discursive cultural constructions which continue to delimit women's experience and identity. For Marlatt, van Herk, and Gunnars, reading and writing are personal and political, historical and imaginary, violent and compassionate de- and reconstructive acts of resistance, which work towards material feminist goals by recognizing that "writing and reading are always hi torically and socially situated events, performed in the world and upon the world by ideologically situated individual and collective human agents" (Montrose, 1992: 415). Marlatt engages in a historical revisionist "writing against her absence" praxis (47); an embodied reading in, of, and through the trope of desire. The focus shifts from historical to literary discursivities in I'laces liur 
lirom lillesmere, where van Herk practices a literary revisionist reading and rewriting of Tolstoy's Ana Karenın. Van Herk engages a "whole" (83) and "visceral" (80) reading; a compassionate reading in which the reader figures as friend (77). As is similarly the case in Marlatt and van Herk, Gunnars proposes a reading at once historical, political, and personal. However, Gunnars shifts the focus from van Herk and Marlatt's compassionate and embodied reading and writing praxes to a more subversive and confrontational cold war writing - a writing as an act of truancy, a prowling. In The Prowler reading and writing are imaged through rhizomatic, labyrinthine, and numerous other implosive models, which signify disruption.

Feminist theory and postmodern aesthetics impact at the nexus of history and subjectivity in the projects of Marlatt, van Herk, and Gunnars, providing an ethically responsible and politically activist feminist-postmodernist framework from which to reconstruct female subjectivity. Ana Historic. Places Far From Hillesmere, and The P'rowler engage the postmodern trope of metafiction (fiction-making) and the postmodem historiographic trope of metahistory (history-making) from a feminist context ${ }^{c}$ identity politics, in order to reframe historiographic metafiction from the context of the gender- and otherwise marked subject. Van Herk explores subjectivity from the singular context of gender; Marlatt frames the subject from positions of gender and sexuality; and in Gunnars, the subject is marked by ethnicity, nationality, class, and age, in addition 
to gender. What is integral to these text's opening up of subjectivity, is that they avoid rearticulating any essentialist subjectivity inrough a politics of location. As Borsa notes. the radically contextualized subject in process is grounds enough for agency: "cultural identification need not produce 'an essence but a positioning.' not a fixed point but a point of transition, a place I see as a reference point... a site 'subject to the continuous play of history. culture and power" (1990:36-7).

Ana Historic, Places far firom Ellesmere, and The Prowler trouble the borders between genres and disciplines; between personal and political; between activist and academic. The fiction-theory of Marlatt, van Herk, and Gunnars is representative of a growing body of academic, literary-theoretical writing by women, at once postmodern and feminist, which actively engages in feminist politics. The feminist-postmodernist projects of Marlatt, van Herk, and Ciunnars work "not merely to interpret literature [but] to change the world" (Schweikart. 1989: 24). Through an incorporation of postmodernist aesthetics, these texts underscore the danger of totalizing systems of thought, and repeatedly remind us that our truths are necessarily fraught with ideology anci provisional at best. Equally meta-feminist, however, these texts work to deconstruct cultural constructs in order to establish tenable locations and positions from which to carry out an activist pelitical and ethical agenda under the sign of women. The junctures of meta-feminism and postmodern aesthetics, as contemplated in the projects of 
Marlatt, van Herk, and Gunnars "are exactly where responsibility beyond innocence looms as a promise and a frightening necessity" (Flax, 1993: 147).

Marlatt, van Herk, and Gunnars offer aiternative possibilities by, for, and about women by politicizing the very terms through which identity is articulated (Butler, 1990: 148). In texts where women narrators and characters are portrayed acting upon, and changing, the historically, linguistically, and literarily organized world. Marlatt, van Herk, and Gunnars put pressure on the cultural constructions of the female subject in the nineteenth and twentieth centuries. Gender, sexuality, ethnicity, geography, and class offer tenable sites from which to act politically upon the world, sites from which to engender alternative feminist reading, writing, and representational praxes. The shifting and transitory site of female subjectivity is marked by various signs in the three texts - woman as immigrant and prowler in Gunnars; woman as explorer, transient, and nomad in van Herk; and, woman as pioneer in Marlatt - all of which open the sign of 'woman' to an endless play of signification of the subject in process. 


\section{Bibliography}

Primary Texts

Gunnars, Kristjana. The Prowler. Alberta: Red Deer College Press, 1989

Marlatt, Daphne. Ana Histork: Toronto: The Coach House Press. 1988.

Van Herk, Aritha. Macess l'ar l'rum Fllesmere. Alberta: Red Deer College Press. 1990.

Theory

Alcoff, Linda. "Cultural Feminism versus Post-structuralism: The Identity Crisis in Feminist Theory." fiementst Theory in Practice and l'rocess. Ed. Micheline R. Malson et al. Chicago and London: The I niversity of Chicago Press, 1989. 295-326.

Avis, Walter et al. (iage' ('anadhan I)chomary. Toronto, Ontario: (jage Educational Publishing Company. 1983.

Barthes, Roland. "Death of the Author." Image-Mfusic-Text. Fd. and Trans. Steven Heath. London: Fontana, 1977. 142-148.

Baudrillard, Jean. "The Precession of Simulacra." The P'essmedern Reduler. Trans. Paul Foss, Paul Patton and Philip Beitchman. Ed. Joseph Natoli and Linda Hutcheon. New York: State University of New York Press, 1993. 342-75.

Benhabib, Seyla. "Feminism and the Question of Postmodernism." licmimst Lillerary Theory: A Reader. Second edition. Ed. Mary Eagleton. Cambridge, Mass.: Blackwell, 1996, 373-78.

Bessner, Neil. "Beyond Two Solitude;, After Survival- Postmodem Fiction in Canada." Pustmodern fiction in ('anada. Ed. Theo D'haen and lians Bertens. Amsterdam: Rodopi, 1992. 9-25.

Bordo, Susan. "Feminism, Postmodernism, and Gender-Scepticism." Feminism l'ustmodernism. Ed. Linda J. Nicholson. New York and London: Routledge, 1990. 133-56. 
Borsa, Joan. "Towards a Politics of Location: Rethinking Marginality." ('anculuan Woman Situdes. 11.1 (Spring 1990) 36-9.

Braidotti, Rosi. Nomadic Suhjects: limbodiment and Sexwal Infference in ('ontemporary li'mentst Theory. Included in Heminist Literary Theory: A Reacker. Second edition. Ed. Mary Eagleton. Cambridge, Mass.: Blackwell, 1996. 411-20.

Bucknell, Brad. "Not Quite the Last Post: The Problems of Theory and History." Ariel: A Reve't of Imernational ling/tsh Literature 24.2 (1993) 115-130.

Buss, Helen. Mapping (Hur Selves: ('anadian Women's Autohiography in linglish. Montreal: McGill-Queens UP. 1993.

Butler, Judith. "A Skeptical Feminist Postscript to the Postmodern." P'ostmodernism Across the Ages. Ed. Bill Readings and Bennet Schaber. New York: Syracuse UP, 1993. 223-27.

-. "Contingent Foundations: Feminism and the Question of 'Postmodernism'." liemminsts Theorlze the Political. Ed. Judith Butler and Joan W. Scott. New York and London: Routledge. 1992a. 3-21.

- ciender Trontle: Himmism and the Suhversion of Idenity. New York and London: Routledge, 1990.

-, and Joan W. Scott. "Introduction." liemmests Theorize the Polifical. Ed. Judith Butler and Joan W. Scott. New York and London: Routledge, 1992. xiii-xvii.

Chow, Rey. "Postmodern Automatons." Feminists Theorize the Political. Ed. Judith Butler and Joan W. Scott. New York and London: Routledge, 1992. 101-17.

Cixous. Helene. "The Laugh of the Medusa." Trans. Keith and Paula Cohen. Signs 1 (1976) $281-90$.

Cohen, Ralph. "History and Genre." New L.llerary History 17 (1986) 210.

Cousins, Mark. "The Practice of Historical Investigation." Post-Structuralısm and the Question of History. Ed. Derek Attridge et al. Cambridge, London, New York, New Rochelle and Melbourne: Cambridge UP, 1987. 126-36. 
Creed. Barbara. "From Here to Modernity: Feminism and Postmodernism." t losimodern Reoder. Ed. Joseph Natoli and Linda Hlutcheon. New lork State (Iniversity of New York Press, 1993, 398-418

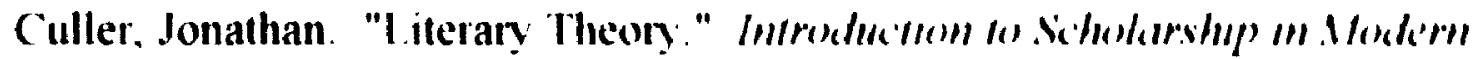

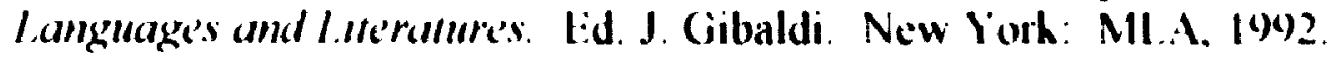
201-35.

Dällenbach. Lucien. Iho Mtrror in the live. Trans. deremy Whitely. ('hicago: University of Chicago Press, 1989.

De Lauretis, Teresa. "Upping the Anti (Sic) in Feminist Theorv." Li'mmms Lilerary Theory: A Reader. Second edition. Ed. Mary lipileton. Cambridge. Mass.: Blackwell. 1996. 382-85.

Deleuze, Gilles and Felix Guattari. "Rhizome". A Thouscomd l'kusums. Trans. Brian Massumi. Minneapolis: (iniversity of Minnesota Press. 1987 3-25.

Derrida, Jacques. ()f ( irammalology. Trans. Gayatri ( hakravorty Spivak. Baltimore and London: The Johns Hopkins UP, 1976.

De Toro, Fernando. "Post-Modern Fiction and Theatricality: Simulation. Deconstruction, and Rhizomatic Writing." ('ancsdesm Ra've'w' of ('omparalne l.tleraiale 21, 3 (1994) 417-443.

Di Stefano, Christine. "Dilemmas of Difference: Feminism. Modernity, and Postmodernism." fieminısm l'ostmodernusm. Lid. Linda J. Nicholson. New York and London: Routledge, 1990. 63-82.

Elam, Diane. Feminusm and l heconstructern. London and New York: Routledge, 1994.

Ferguson, Margaret and Jennifer Wicke. "Introduction: Feminism and Postmodernism: or, The Way We Live Now." Fimmosm annel Posimodermism. Ed. Margaret Ferguson and Jet...: fer Wicke. Durham and London: Duke UP, 1994. I-9.

Findlay, Len. "Otherwise Engaged: Postmodernism and the Resistance to History." linglish Studies in ('anadu 14. 4 (1988) 383-399.

Felman, Shoshana. What Does a Woman Wont' Readeng and Sexual I Mfference. Baltimore and London: The Johns Hopkins UP, 1994. 


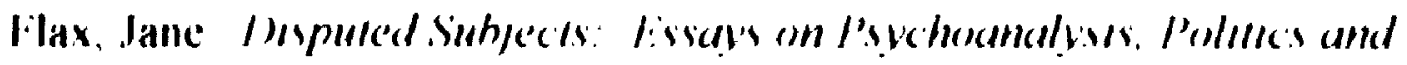
l'hlossophy. New York. Routledge, 1993.

- "The Ind of Innocence " licmmiss Theorize the Pollilcal. Fd. Judith Butler and Joan. W. Scott. New York and l.ondon: Routledge, 1992. 445-63.

.... "Postmodernism and Gender Relations in Feminist Theory." Reminss Theory in I'racice' and l'recesss. Ed. Micheline R. Malson et al. Chicago and I.ondon: The University of Chicago Press. 1989. 51-73.

Foucault, Michel. "What is an Author?" Trans. Josue V. Harari. The fomcuult Reculer. Ed. Raul Rabinow. New York: Pantheon Books, 1979. 101-120.

Iraser, Nancy and I.inda J. Nicholson. "Social Criticism Without Philosophy: An Encounter between Feminism and Postmodernism." lemintsm l'osimodernism. Ed. Linda J. Nicholson. New York and London: Routledge, 1990. 19-38.

Friedman, Susan Stanford. "Post/Poststructuralist Feminist Criticism: The Politics of Recuperation and Negotiation." Ne'w' Literary History 22 (1991) 465-90.

Gates. Ilenry Louis. "The Master's Pieces: On Canon Formation and the Afro-American Tradition." The Bounds of Rac's. Ed. Dominick LaCapra. Ithaca: Cornell UP. 1991. 17-38.

Gilmore, leigh. Autohographucs: A lemenst Theory of Women's SelfRepresentatum. Ithaca and London: Comell UP, 1994.

Godard. Barbara. "Subject to Change: Le Sujet a changer." Te'ssera 9 (1990) $7-14$.

-. "Re: post." Presented at The American Council for Québec Studies in Quebec (ity's October 1988 Symposium - "Feminism and Postmodernism in Qwébec: The Politics of the Alliance." (Zuéhec Studhes 9 (1989/90) $131-43$.

- Daphne Marlatt. Kathy Mezei and Gail Scott. "Theorizing Fiction Theory." ('amalicm lictuon Mlagazine 57 (1986a) 6-12.

-. "Fiction/Theory: Editorial." ('anadian liction Magazıne 57 (1986b) 4-5. 


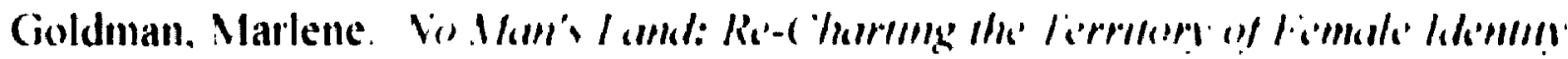

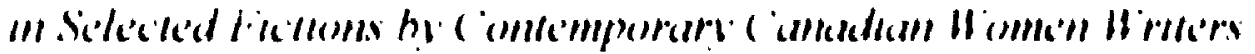
( niversity of Toronto: Doctoral Dissertation. 1943.

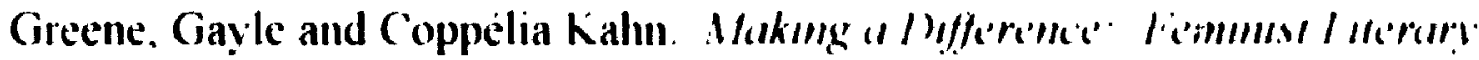
( rilicesm. Ed. Greene and Kahn. New York: Metheun, 1985.

Haraway, Donna. "Situated Knowledges: The Science Question in leminism and the Privilege of Partial Perspective." Simmums, ( yhurgs ams IIImm'nl. I ondon: Free Association Books, 1991. 18.3-201.

- "A Manifesto for Cyborgs: Science, Technology, and Socialıst Feminism in the 1980s." liementsm Losimodermism. Led. Linda J. Nicholson. New Y'ork and London: Routledge, 1990. 190-2.3.

Harding, Sandra. The Secence (Muestum m liemmmsm. Ithaca, New York: Comell UP, 1986.

Hartsock, Nancy. "Foucault on Power: A Theory for Women?"

firmmism l'ostmokermusm. Ed. Linda J. Nicholson. New York and London: Routledge, 1990. 157-75

Henderson, Mae Gwendolyn. "Speaking in Tongues: Dialogics. Dialectics and the Black Woman Writer's Literary Tradition." (olomol I hicomerse amed Post-c 'olomal Theory: A Reocker. Ed. Patrick Williams and I aura Chrisman. New York: Columbia UP, 1994. 257-69.

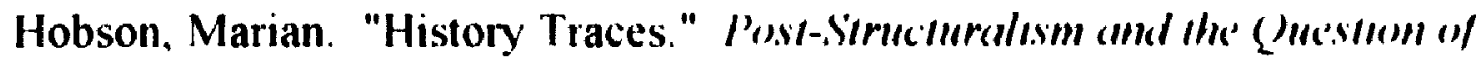
History. Ed. Derek Attridge et al. Cambridge, London, New York, New Rochelle and Melbourne: Cambridge (1P, 1987. 101-115

hooks, bell. "Representation and Resistance: an Inteview with Bell Ilooks." With David Trend. Sicclalist Reve'w (1995) 115-28.

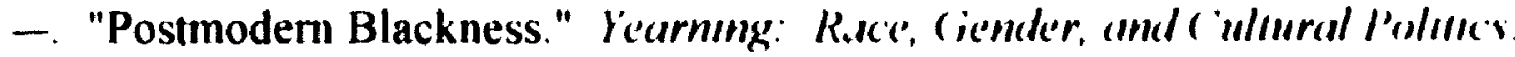
Toronto: Between the Lines, 1990. 23-31

Hutcheon, Linda. "Introduction." Douhle-Talking: Lissans on V'erhal and Visual Ironies in conlemporary ('anadian Art and lileralure'. Iid. Linda Hutcheon. Toronto: ECW Press, 1992. 11-38.

- The Polincs of P'ostmodernism. New York: Roulledge, 1989a. 
- "'Circling the Downspout of I:mpire' Post-Colonialism and Postmodernisın" Ariel $20.4(198 \%)$ ) $149-76$

-.. "Ilistoriographic Metafiction. Parody and the Intertextuality of History."

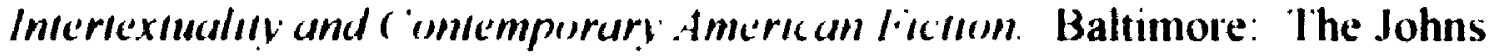
Hopkins (IP. 1989c. 3-32

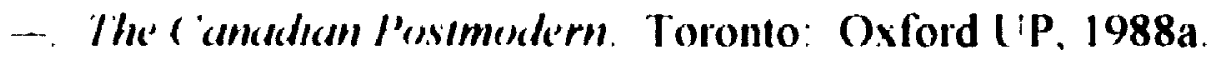

- A l'osics of l'osimodernism. New York. Routledge, 1988b.

"The Postmodern Problematizing of History " linglish Simdies in ( amudu 14: $4(1988 \mathrm{c}) 365-82$.

"'The Pastime of Past 'Time': Fiction, History, Historiographic Metafiction." l'osimodern (ienres. Ed. Marjorie Perloff. Nonnan: Oklahoma UP. $1988 d$. $54-74$.

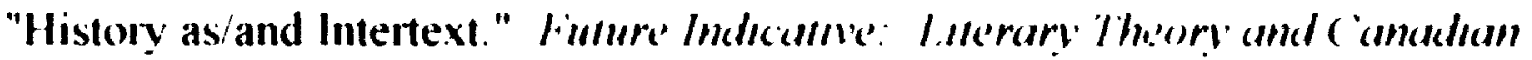
L.lterulure. Ed. John Moss. Ottawa: Ottawa UP, 1986a. 169-84.

"Shape shifters': Canadian Women Novelists and the Challenge to Tradition." A Mazing Space. Eds. Shirley Neuman, Smaro Kamboureli. Edmonton: Longspoon Press, 1986b. 219-27

"Canadian Historiographic Metafiction." Liscans on C amadhan 11 rınng 30 (1984) 228-38.

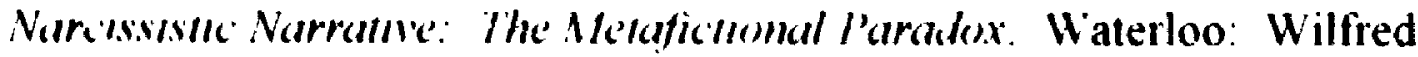
Laurier LP. 1980.

Huyssen, Andreas. "Mapping the Postmodern." ft Posimodern Reculer. Ed Joseph Natoli and Linda Hutcheon. New York: State University of New York Press, 1993. 105-56.

Jencks, Charles. "The Post-Modem Agenda." The Pest-Modern Reacker. Ed. Charles Jencks. New York: St Martin's Press, 1992. 10-39.

Kamuf, Peggy, Ed. Al Merruda Reculer. New York: Columbia UP. 1991.

I aCapra, Dominick. History' sme/ 'rulı'ssm. Ithaca and I.ondon.: Comell UP, 1985 . 
-. "Intellectual History and Definmg the Present as 'Posimodern'"

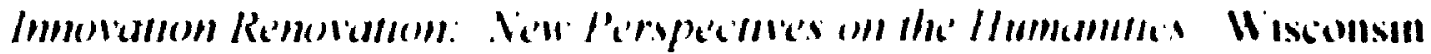
liniversity of Wisconsin Press. $1983 \quad$ 47-6.3

I indenberger, H "Toward (and After) a Vew History in I Iteran Stud!" Ih'

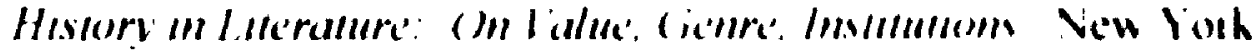
Comumbia ('P. 1990. 189-210

Lovibond, Sabina. "Feminism and Postmodernism." Penmmekermom 1 Ridukr Fd. Thomas Docherty New Yorh. Columbia ('P. 190); i9(1-414

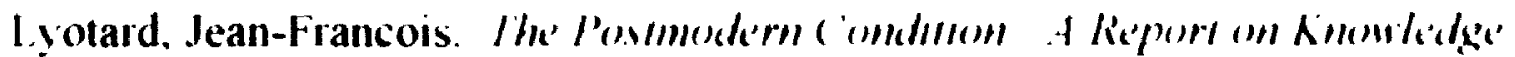
Trans. Geoff Bennington and Brian Massumu. Minncapolıs. I mmetsity of Minnesota Press. 1984.

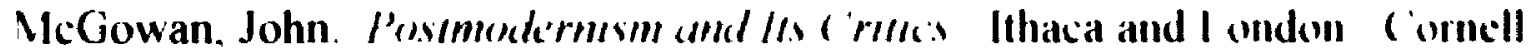
('P. 1991

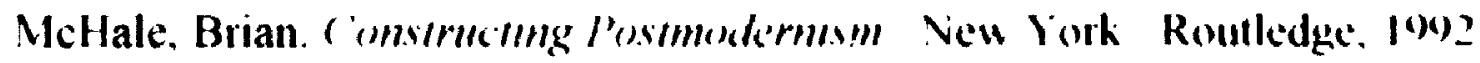

-. Mosimoderms inctom. New York. Methuen, 1987

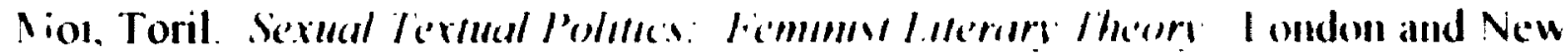
York: Routledge, 1985.

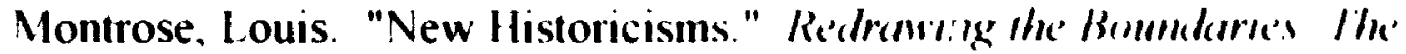

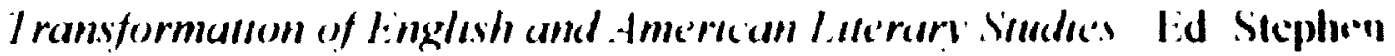
Greenblatt and Giles Giunn. New York: Modem I anguage Associatıon of America. 1992. 392-418.

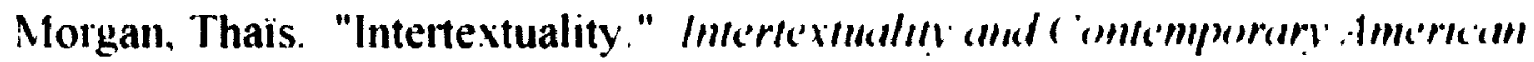
Fikllun. Ed. Patrick O'Donnell, Robert (on Davis Ballumore The Johns I 'opkins I P. 1989. 239-279.

Natoli, Joseph and Linda Hutcheon. "Introduction." A lessmesierm Reculer lid Linda Hutcheon and Joseph Natoli. New York: Stane Inversity of New York Press, 1993. vii-xiv.

Nicholson, Linda J. "Feminism and the Politics of Postmodernism." I.c'mums.sm and Postmoderms.m. Ed. Margaret Ferguson and Jennifer Wicke. Durham and London: Duke UP. 1994. 69-85. 
-. "Introduction." leemınısm l'esimodernism. Ed. Linda J. Nicholson. New York and I.ondon: Routledge, 1990. 1-16

Owens, (raig. "The Discourse of Others Feminists and Postmodernism." The l'esi-Modern Reader. Ed. Charles Jencks. New York: St Martin's Press. 1992. 333-48.

Paterson, Janet. Moments Posimodernes dans le roman quehecons. Ottawa: Presses de l'Universite d'Ottawa. 1991.

Poovey, Mary. "Feminism and Deconstruction." liemmist liferary Theory: A Reader. Second edition. Ed. Mary Eagleton. Cambridge, Mass.: Blackwell, 1996. 262-7.

-. "Feminism and Postmodernism - Another View." Firmınısm and Posimudermism. Ed. Margaret Ferguson and Jennifer Wicke. Durham and London: Duke UP. 1994. 34-52

Rich, Adrienne. "Bloud, Bread, and Poetry: The Location of the Poet." Blood, Bread, and l'oerry. New York: W.W. Norton and Company, 1986. 167-87.

-. "Resisting Amnesia: History and Personal Life." Blood, Bread, and Poc'rry". New York: W.W. Norton and Company, 1986. 136-55.

Saurette, Leon. "Modicnism, Postmodernism. Fascism, and Historicism." ('merersily of Torome (nacrlerly: A canadian Journal of the Humamices 60. 4 (1991) 476-92.

Schweikart, Patricinio. "Reading Ourselves: Toward a Feminist Theory of Reading." Speaking of (jender. Ed. Elaine Showa!ter. New York: Koutledge, 1989. 17-44.

Showalter, Elaine. "Towards a Feminist Poetics." Ie'mmst Llterary Theory: $A$ Reader. Second edition. Ed. Mary Eagleton. Oxford: Blackwell, 1994. 254-7.

Simon. Sherry. "(Feminist) Forms of Postmodernism." Presented at The American Council for Québec Studies in Quebec City's October 1988 Symposium -"Feminism and Postmodernism in Quebec: The Politics of the Alliance." (Huchec Siudres 9 (1989/90) 143-6. 
Simpson. David. "Feminism and Feminization in the Postmodern." $1.2 m m ! n s m$, $u m$ l lesimodermsrr. Ed. Margaret Ferguson and Jennife: W'icke. Durham and London: Duke ( P. 1994. 53-68.

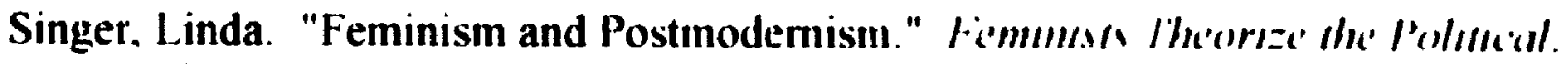
Ed. Judith Butler and Joan W. Scott. New York and Routledge, 190)2. 464-75.

Smart, Patricia. "Postmodern Male Narratives." Presented at The American Council For Québec Studies in Quebec City's October 1988 Symposium "Feminism and Postmodernism in Quebec: The Politics of the Alliance." Quihec Studies 9 (1989/90) 146-51.

Straub, Kristina. "Feminist Politics and Postmodernist Style." Image' amd Ideolegv in Modern l'osimodern Inscourse. Ld. David B. Downing and Susan Bazargan. New York: State University of New York Press, 1991. 273-286.

Sulciman, Susan Rubin. "Feminism and Postmodernism: A Question of Politics." The Pesst-Modern Reader. Ed. Charles lencks. New York: Si Martin's Press, 1992. 318-32.

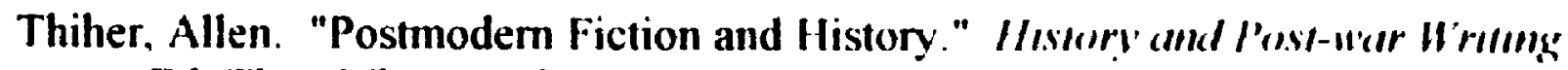
Ed. Theo D'haen and Hans Bertens. Amsterdam: Rodopi, 199(), 9-31.

Waugh, Patricia. Metafic IImn. New York: Routledge, 1984.

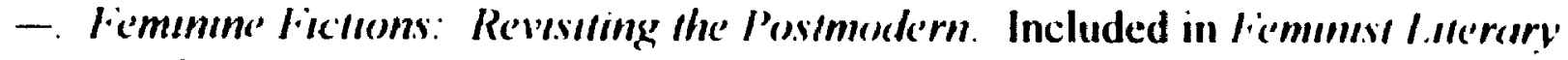
Theory: A Reader. Second edition Ed. Mary Eagleton. ('ambridge, Mass.: Blackwell, 1996. 360-63.

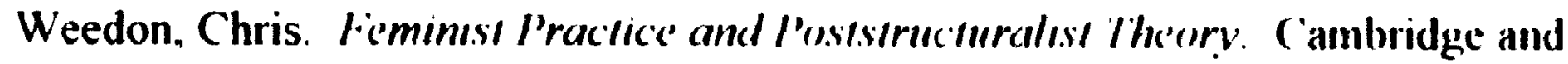
Oxford: Blackwell, 1987.

West, Cornel. "The New Cultural Politics of Difference." (Int There. Marginalizatıon and contemporary c 'ullure's. Fed. Russell lerguson et al New York: The New Museum of Contemporary Art, 1990. 19-36.

-. "Black Culture and Postmodernisı. R Remakıng Histıry. Fd. Barbara Kruger and Phil Mariani. Seattle, Wash.: Bay Press, 1989. 87-96. 
White. Hayden. "The Question of Narrative in C'ontemporary Historical Theory." IIstory and Theory 23.1 (1984) 1-33.

-. Truphes of I Jescourse. Baltionore: The Johns Hopkins L P. 1978.

-. The Conne'nt as liorm. Baltimore' The Johns Hopkins UP, 1987.

Wicke, Jennifer. "Postmodem Identittes and the Politics of the (legal) Subject." liemmis.sm and l'osimodermısm. Ed. Margaret Ferguson and Jennifer Wicke. Durham and I ondon: Duke UP. 1994, 10-32.

Yeatman, Anna. "A Ferminist Theory of Social Differentiation." lirmminsm l'osimodernism. Ed. Linda J. Nicholson. New York and I.ondon: Routledge. 1990. 281-99.

Young. Robert M. "Postmodernism and the Subject: Pessimism of the Will."

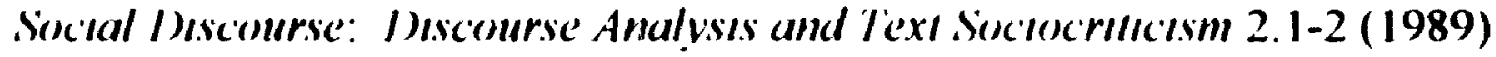
69-82.

\section{Criticism:}

\section{Kristjana Giunnars}

Baldvinsson, Gardar. "Cold War." ('anadhan J.sleralure' 135 (1992) 157-58.

Gheorge, Cristina. "Intertextual Notes in a Metafictional Autobiography." icandencrinan-c 'anadian Sinches 4 (1991) 43-9.

(iunnars, Kristjana. "In that gap where one searches, the muse hangs around..." somnding I Ifference": Conversation with Sevemeen ( anadian Women Wrikers. Interview with Janice Williamson. Ed. Janice Williamson. Toronto: Toronto UP, 1993.

-. "Interview with Kristjana Gunnars about The Prow/ler." With Cristina Gheorge. Scandinaivan-C 'anadian Sindies 4 (1991) 51-9

-. "The Present." Language in Her lyye: View's on Wriling and (iender by' fanadian Women Writıng in linglish. Ed. Libby Scheier, Sarah Sheard and Eleanor Wachtel. Toronto: Coach House, 1990. 126-30.

Keefer, Janice Kulyk. "The Prowler." Brick 51 (1995) 52-7. 
Kenyon. Michael. Review of Kristjana Gunnars' Ihe I'row/ler. I/h' I tuluhul R.'1k'll 91 (1990) 50.

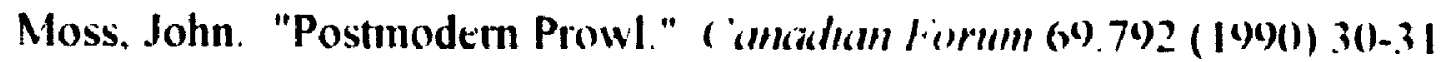

Owen, Robert. "Seeking the Right Voice." Alherlu Report May 28 (19)(0) 50-51.

Owens, Judith. "Drawing/in': Wholeness and Dislocation in the Work of Kristjana Gunnars." ('omemporary M/amloha llirle'rs l:d. Kenneth James Hughes. Winnipeg: Turnstone Press, 1990.

\section{Daphne Marlatt}

Brand, Di. "The Absence at the Centre." The camcallum lourum 58.779) (1989) 8-40.

Chan, Celine. "Lesbian Self-Naming in Daphne Marlatt's Amu Hos/urre:" ('anadian loctry: Siludes, Docume'nts. Re'v'e'ws 31 (1992) 68-74

Cooley, Dennis. "Recursion Excursions and Incursions: Daphne Marlatt Wrestles with the Angel Language." L.me' 13 (1989) 60-79).

Dragland, Stan. "Out of the Blank: Ana Hestorre." The Bees of the Intesthle:

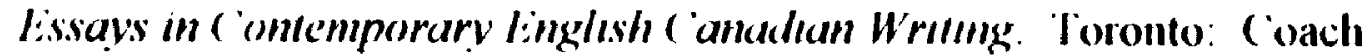
House, 1991. 172-90.

Goldman, Marlene. "Daphne Marlatt's Ana Historic: $A$ Genealogy for Lost

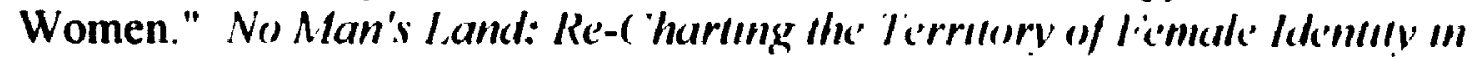
iclected lickleons hy confemporary c anadean Wome'n Wrifers. Liniversity of Toronto: Doctoral Dissertation, 1993. 116-154.

Grise, Annette C. "'A Bedtime Story for You, Ina': Resisting Amnesia of the Maternal in Daphne Marlatt's Ana llishork:" Fesscera 15 (1993) 9(1)-98.

Jones, Manina. "'I quote myself or, A Map of Mrs Reading. Re-siling 'Woman's

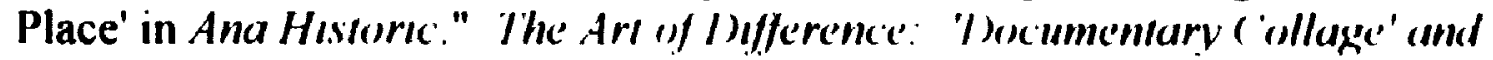
linglish-C anadian Writing. Toronto: Toronto (IP, 1993.

Kelly. Peggy. "Fiction Theory as Feminist Practice in Marlatt's Aner Hes/urre and Scott's Herome" (Jpen ledler 9.4 (1095) 69-98. 
Marlatt, Daphne. "'When we change language..."' Simundeng l luffere'nce's:

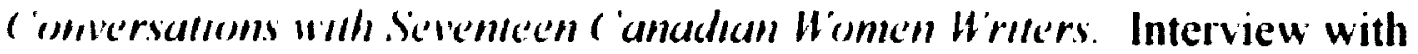
Janice Williamson. I:d Janice Williamson. Toronto: Toronto ( P. 1993. $182-93$.

- "Iifference (em)bracing." Language in Her live. Ed L ibby Scheier, Sarah Sheard and I:leanor Wachtel. Toronto Coach House Press, $1990 \quad$ 188-93.

"On Amo I/sstorrc. An Interview with Daphne Marlatt." With George Bowering. I.Im' 13 (1989) 96-105.

Matson, Patricia. "(Re)Creating History." L's'm 18.1 (1989) 131-.34.

Quednau, Marion. "Acts of the lmagination." Books In ('incula (November 1988) $33-35$.

Tostevin. Lola I emire. "Daphne Matlatt: W'riting in the Space that is Her Mother's Face." LInc' 13 (1989) 29-32.

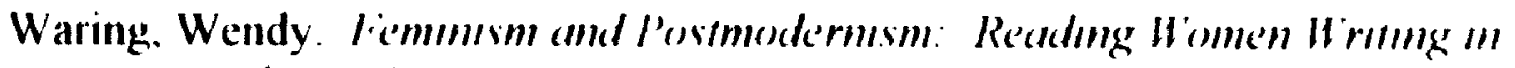
rimude. I 'niversity of Toronto: Doctoral Dissertation. 1992.

\section{Iritha van Herk}

Beer. Antr. "Thinking Too Precisely On Some Events." Border ( rossings (1991) $35-6$.

Cameron, Flspeth. "Sweet Sub/ V'ersions: The Femmizing Fffect of Postmodernism on Canadian Literature." ( amadian Reverew of comparatne l.ll'rulur' 20.1-2 (1993) 479-89.

Goldman, Marlene. "Abandoning the Map: From Cartography to Nomadology -the Fiction of Aritha van Herk." No Marr's land: Re-( Harning the

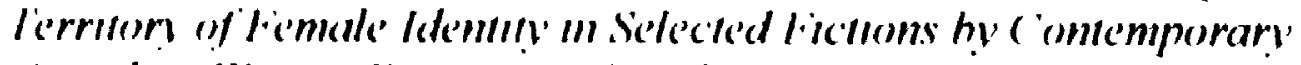
('amediem IIome'n IIrikers. University of Toronto: Doctoral Dissertation, 1993. 155-98.

-. "Farth-( Quahing the Kingdom of the Male Virgin: A Ueleuzian Analysis of Aritha van Herk's Ne lined Address and Ilaces liar lirom l:llesmere." (imudum l.1k'rumure 137 (1993a) 21-38.

Gom. Leona. "Places Far From Home." Liven 20.2 (1991) 125-7. 


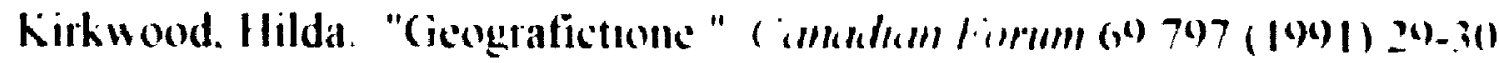

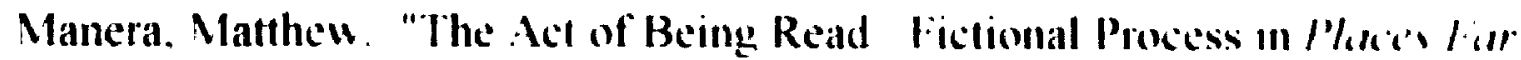

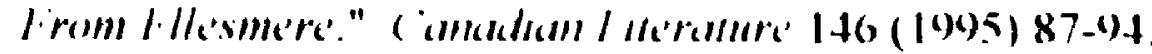

Thomas, Joan. "Revew of Placen liar lirom lillevmere" l'rurme lime 12 2(1001) $68-70$

V'an Herk. Aritha "In V'isible Ink." In I whh/l Irh I:dmonton. Vltal NeWest Press. 1991. 1-11

-. "Of Viscera and Vital Questions." In lishle link fidmonton. Mlta. NeWest Press, 1091. 129-137.

-. "Kiss of the Spider-1 ady: An Interview with Aritha van Herk" With Ihlda Kirkwood. ('amceleun 11 immom Stude's 8.3 (1987a1) 85-9)

-. "Interview with Aritha Van Herh." With Dorothy Jones ST:IN (1987b) 1-15

- "Double Crossings: Booking the L over." A M/azmg Sperce lid Shirky Neuman and Smaro Kamboureli. Edmonton: Longspoon Press. I Y8oa 276-86.

-. "Interview." With Gyrid Jerve. Kinnapy" 8.3 (1986b) 68-76.

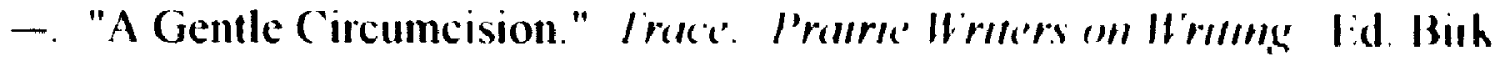
Sproxton. Winnipeg: Turnstone Press, 1986c. 257-68.

-. "Women Writers and the Pranie Spies in an Indifferent I andscape " Kunupipı 6: 2 (1984a) 15-25.

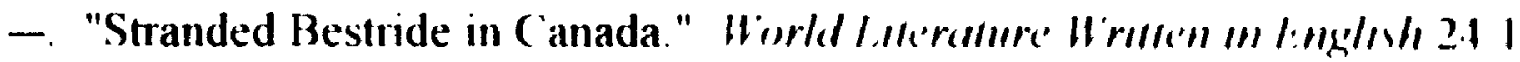
(1984b) 10-16.

Wiebe, Rudy. "The Elusive Meaning of 'North'," c amudum ciongrophluc January tebruary (1996) 83 

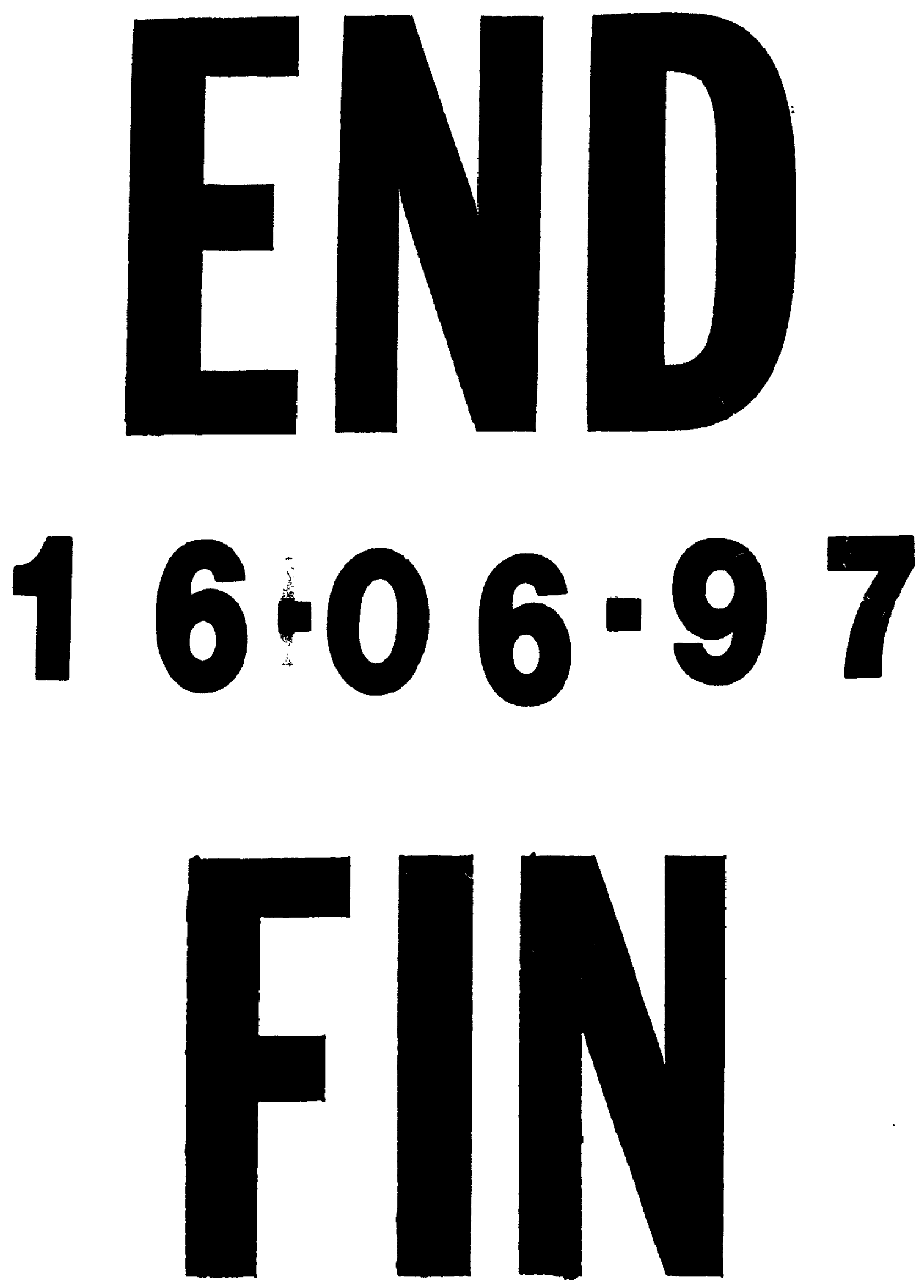